Historic, Archive Document

Do not assume content reflects current scientific knowledge, policies, or practices. 



\section{The Timber Resources}

of MAINE

\section{A Report on the Forest Survey made by the U.S. Forest Service}
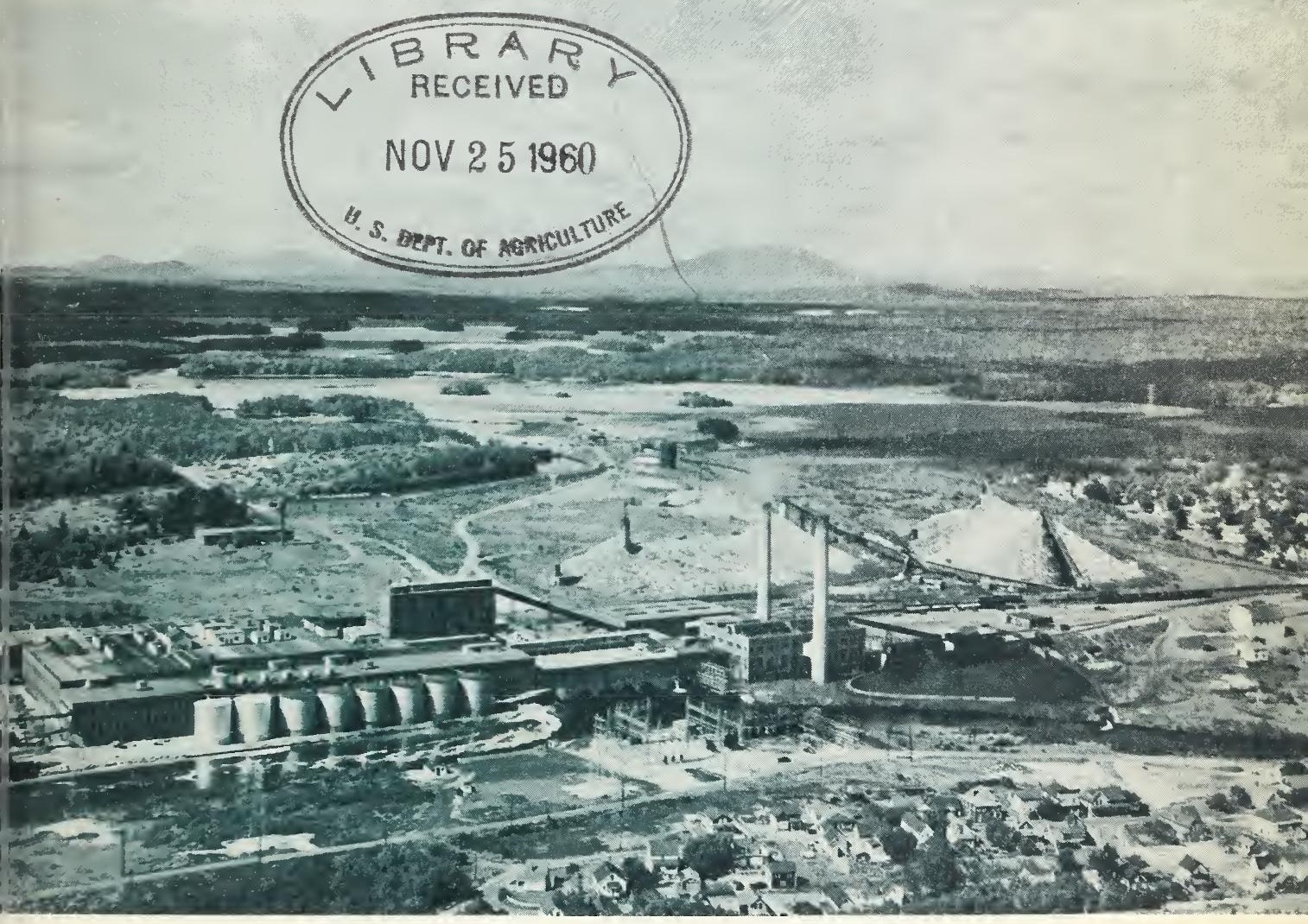

NORTHEASTERN FOREST EXPERIMENT STATION

FOREST SERVICE - U.S. DEPARTMENT OF AGRICULTURE - UPPER DARBY, PA. 


\section{UNITED STATES \\ DEPARTMENT OF AGRICULTURE \\ LIBRARY}

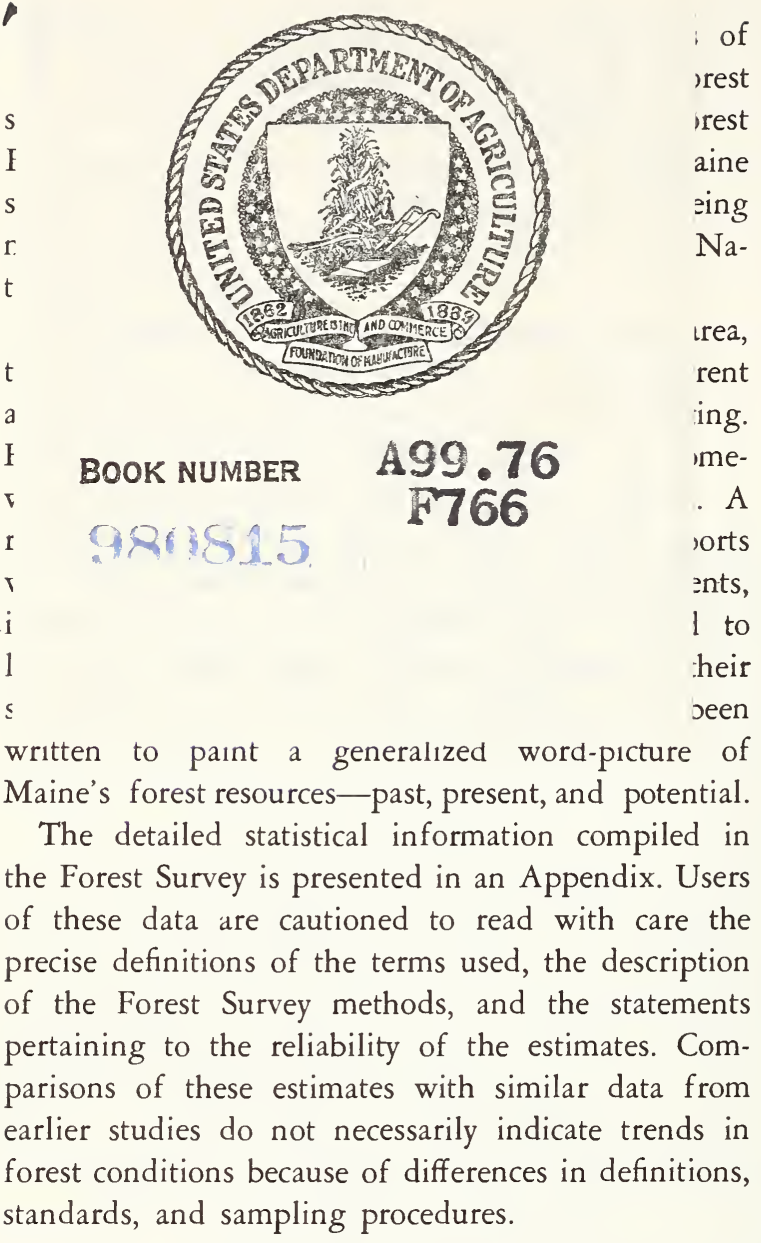

of

rest

irest

aine

sing

$\mathrm{Na}-$

rea,

rent

ing.

me-

A

orts

nts,

1 to

heir

seen

written to paint a generalized word-picture of Maine's forest resources-past, present, and potential. The detailed statistical information compiled in the Forest Survey is presented in an Appendix. Users of these data are cautioned to read with care the precise definitions of the terms used, the description of the Forest Survey methods, and the statements pertaining to the reliability of the estimates. Comparisons of these estimates with similar data from earlier studies do not necessarily indicate trends in standards, and sampling procedures.

THE COVER

Honzes, industries, water, and vast reaches of forest land symbolize the multiple benefits that the people of Maine get from their forest resource. Photo by courtesy of Great Northern

Paper Company. 


\section{The Timber Resources of MAINE}

ROLAND H. FERGUSON and FRANKLIN R. LONGWOOD

Northeastern Forest Experiment Station

Forest Service, U. S. Dept. Agriculture

ROLAND H. FERGUSON is a forest economist in the Northeastern Forest Experiment Station's Division of Forest Economics Research. He received his Bachelor of Science degree in forestry at Oregon State College in 1931, and joined the U. S. Forest Service in 1934. After serving in the southern pine and Douglas-fir regions, be came to the Northeast in 1945, since which time he has been engaged in various aspects of the Forest Survey.

FRANKLIN R. LONGWOOD is research center leader at the Bangor Research Center of the Northeastern Forest Experiment Station, U. S. Forest Service, Bangor, Maine. He graduated from Michigan State University in 1938 and received his Master of Forestry degree from Oregon State College in 1940. After graduation be served 4 years in National Forest administration, 2 years in farm woodland management, and 14 years in research, specializing in forest management, utilization, and products. He has worked in the spruce-fir region of Maine since 1956. 


\section{CONTENTS}

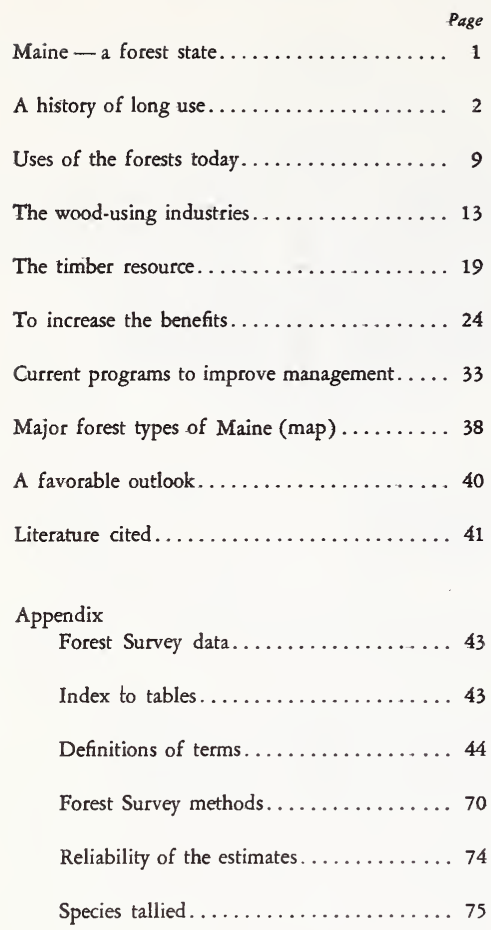



using companies provide more employment than any other industry in Maine. And more than a third of the value of all of Maine's manufactured products is produced by these same forest-products industries $(9)^{1}$. The actual value of other forest products is more difficult, if not impossible, to calculate, because these products are not bought and sold and thus do not have prices.

This diversity of uses also means that the many people who are concerned with this resource may not always agree on just how a forest should be managed and used. No single point of view is likely to provide a complete basis for deciding the most appropriate program of management for Maine's forests. Fortunately, however, a well-managed forest resource can provide many benefits simultaneously.

Let's turn for a closer look at these forests. Let's look first to see how they have served Maine's people over the past three and a half centuries; then let's take a somewhat closer look at the benefits they are providing today; and finally, let's look at the present timber resource and consider ways of increasing the benefits from Maine's forests by improved management practices.

\section{A History of Long Use}

M

AINE'S forests have supplied wood to a growing nation for more than 350 years. Yet they are still the State's most valuable natural resource.

The first recorded exploitation of the State's forests occurred in 1605 when Captain George Weymouth sailed up one of Maine's rivers and collected samples of white pine, which he took back to England for display (5). The name "Weymouth pine" is still used in the trade. Two years after Captain Weymouth's visit, the Popham colonists arrived in Maine and built the first ship to be constructed by English-speaking people in the Western Hemisphere. This little ship of 30-tons, built at Sagadahoc (now Bath) in 1607, was the first of many thousands of Maine-built wooden ships.

The first commercial shipyard was established on Richmond Island in 1632. Utilizing the abundant supply of pine, ${ }^{1}$ Numbers in parentheses refer to Literature
Cited, page 41 . oak, and "hackmatack" (tamarack, larch), this industry flourished for the next 200 years. By 1855, when the United States possessed the world's largest merchant marine, more than half of its wooden ships had been built in Maine. As late as 1840 , shipbuilding was the State's second largest industry, surpassed only by textile manufacturing. However, after 1860, shipbuilding in the State declined rapidly as iron replaced wood in ship construction (17).

The date and location of the first sawmill in Maine are unsettled. Some say it was at York, in 1623. A carpenter, James Wall, made a deposition stating in part that ". . . about the year 1634 , he and his partners . . . did build upp at the fall there (called by the Indian name of Asbenbendick) ... one sawe mill and one stamping mill for corn wch we did keep the space of three or four years next after." This took place on Great Works River at what is now called South Berwick (15). Though sawmilling spread slowly up the Saco, Kennebec, Penobscot, 


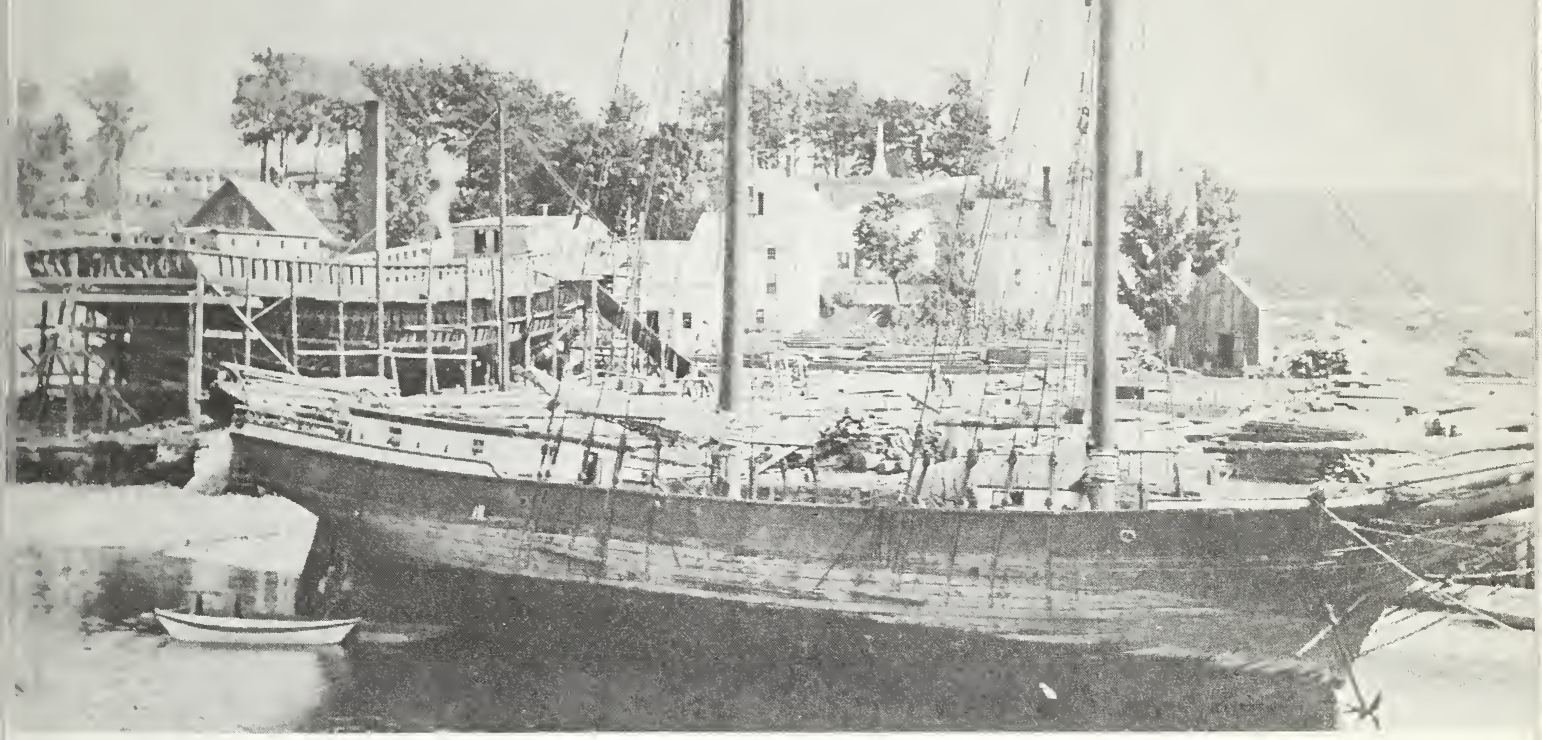

From Maine's forests came the timber that for 200 years supported a worldfamous shipbuilding industry. Thousands of wooden ships sailed from Maine shipyards like this one at Brewer.

Littlefield Safe \& Lock Co. photo
Bangor Public Library photo

Shipbuilding demanded buge quantities of wood. The timbers that went into this ship were hand-bewn in the woods and bauled 20 miles by team to the shipyard.

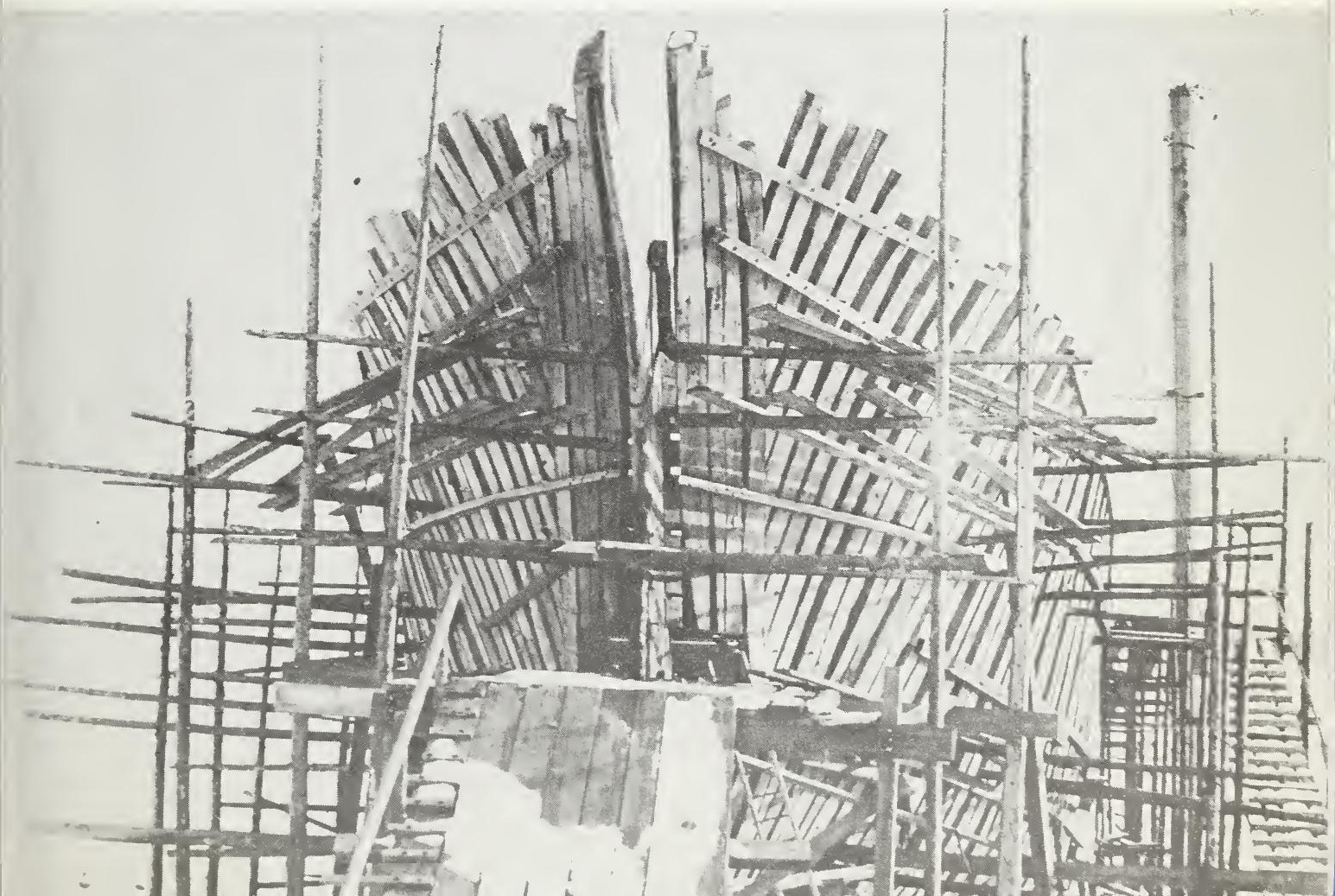




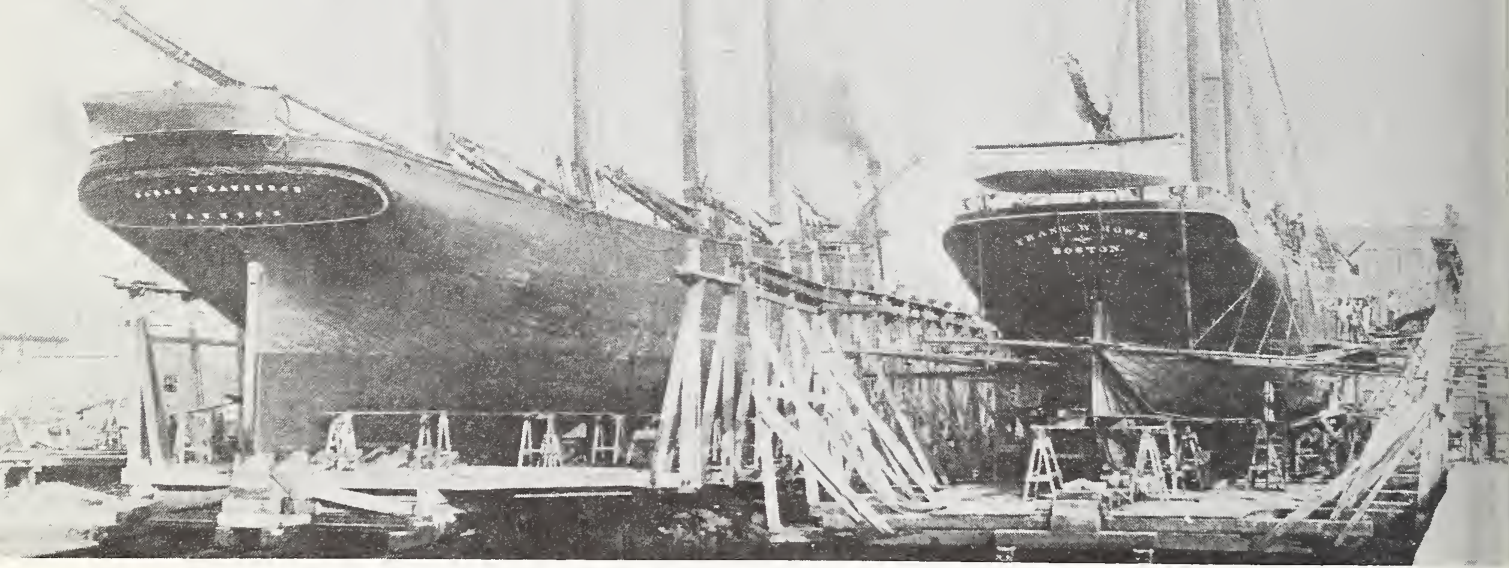

Early sailing ships in drydock at a Maine sbipyard.

Littlefield Safe \& Lock Co. photos

The Augustus Babcock ready for launching at the McGilvery shipyard in Brewer, about 1880. By this time iron was replacing wood in ship construction, and shipbuilding was on the wane.
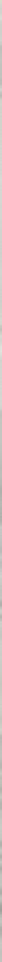
Androscoggin, Salmon Falls, and other coastal waterways, the production of sawed lumber in Maine did not gain national importance until 200 years later (26).

Early explorers and the settlers who followed were amazed at the great abundance of tall, straight pines growing close to the shores of Maine's numerous streams, bays, and estuaries. The European countries had faced a shortage of mast-trees for ships for centuries. Having found what appeared to be an almost inexhaustible supply, the colonists lost no time in developing a mast industry along the Kennebec and Saco rivers. Portland became the center of operations.

The English soon recognized the importance of the New England pines, and in 1691 they instituted their Broad Arrow Policy. Under this policy all pine trees over 24 inches in diameter and standing within 3 miles of water were reserved for the Royal Navy. In practice, however, this arrow mark served more to identify the best mast and lumber trees for the colonists than to discourage cutting. The English attempted sporadically to enforce this policy until the start of the Revolutionary War. But they had little success. By 1774, Maine had wrested first place in mast production from New Hampshire (26). The industry's prosperity continued until the rise of the lumber industry late in the first half of the nineteenth century.

Hand-rived pipe (barrel) staves were one of the first products exported from the Maine forests. By 1634 a Pipe-Stave Landing was recorded on the Great Works River at South Berwick (1). White oak staves were first sent to England, and soon after to the West Indies. They were also shipped to Madeira and the Canary Islands. The staves were used for hogsheads to store and ship rum, wine, sugar, and molasses. When the for- eign stave trade declined, a local cooperage trade developed to supply casks for the shipment of lime from Knox County.

Shingles were another early export. As late as 1840 shingles were used as a medium of exchange in Aroostook County. White cedar and white pine bolts were split with mallet and froe and then the shingles were shaved by hand. This was done for nearly 200 years before the first shingle saw was introduced in Maine.

Tanning of leather was another early industry based in part on the forests. By 1810 some 200 small tanneries in Maine

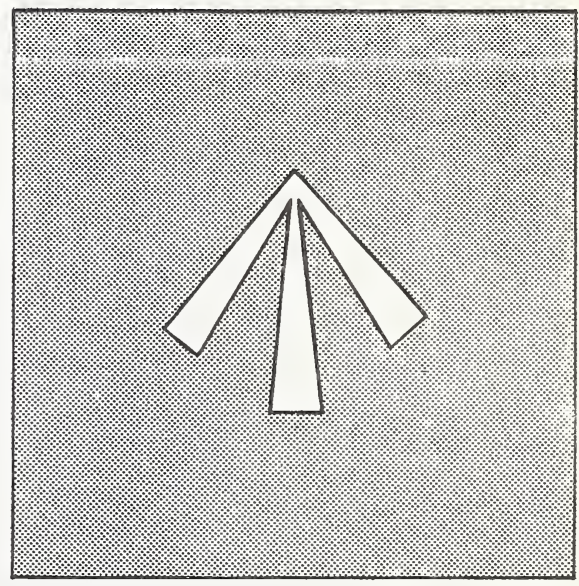

The King's Broad Arrow, the mark used to reserve shipmast trees for the Royal Navy. The colonists bad little respect for it.

were using tannic acid from hemlock bark. By 1860 tanning was the State's third largest industry, exceeded only by the manufacture of textiles and lumber. The tanning industry reached its peak during the period $1870-90$, fell to second place by 1900 , and declined rapidly afterwards. The last purchase of hemlock bark by a Maine tannery was in 1956.

- Tanneries required large quantities of hemlock bark in their tanning processes. This bark was obtained by stripping felled hemlock trees. The logs themselves 
were not salable, so they were left in the woods to rot. This industry accounted for the cutting of millions of hemlock logs. One unpublished study indicates that the total volume cut was more than 9 billion feet, of which only a fraction was utilized.

The advent of the lumber industry can be traced from the timberlands around Massachusetts Bay into the Province of New Hampshire and then into Maine at about the beginning of the 18th century. Beginning first along the Saco river, the industry moved slowly to the north and east, reaching the Aroostook area in the early 1800s. Timber cutting was limited almost exclusively to pine during the colonial period, when Maine dominated the lumber industry (4).

Maine can claim many firsts and nearfirsts in the lumber industry. George and Richard Leader constructed what is believed to be the first sash gangsaw on this

In the lumber industry, Maine has been a leader since its earliest days. Hauled to the Penobscot River by team, these logs were floated downstream to Bangor. continent at South Berwick, in 1651. This mill had 19 saws cutting simultaneously - a big advance beyond the usual onesaw operations. Though Benjamin Cummings patented the first circular saw, this innovation did not come into general use until after the patent of a circular saw by Eastman and Jacquith of Brunswick. The first of these circular saws was installed on the Kenduskeag Stream by John Webster. By 1824 a circular saw was also operating in Waterville.

Steam began to replace waterpower at about the time that circular saws were coming into use. A steam sawmill is recorded at Bath in 1820 or 1821 ; another on the Penobscot River at Hampden in 1835. By 1850, there were 36 steampowered mills in Maine. Band saws, which never became numerous in Maine, were first used in the State in 1889.

Although the State became famous as a lumber center during the 19th century, it did not hold first place in the lumber industry after 1800 (26). By 1840, when Maine ranked second to New York in lumber production, the center of the in-

Scott Paper Co. photo

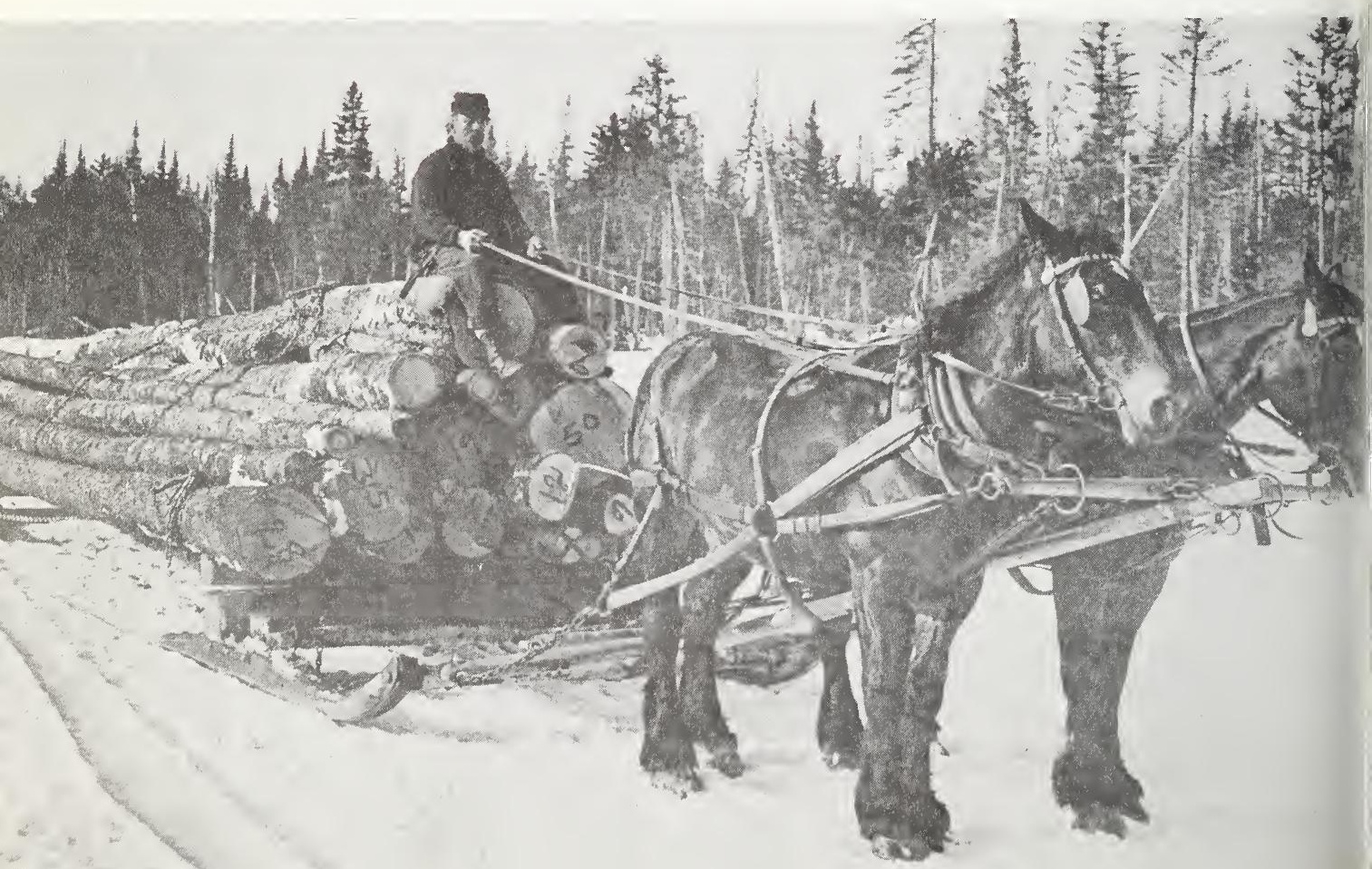




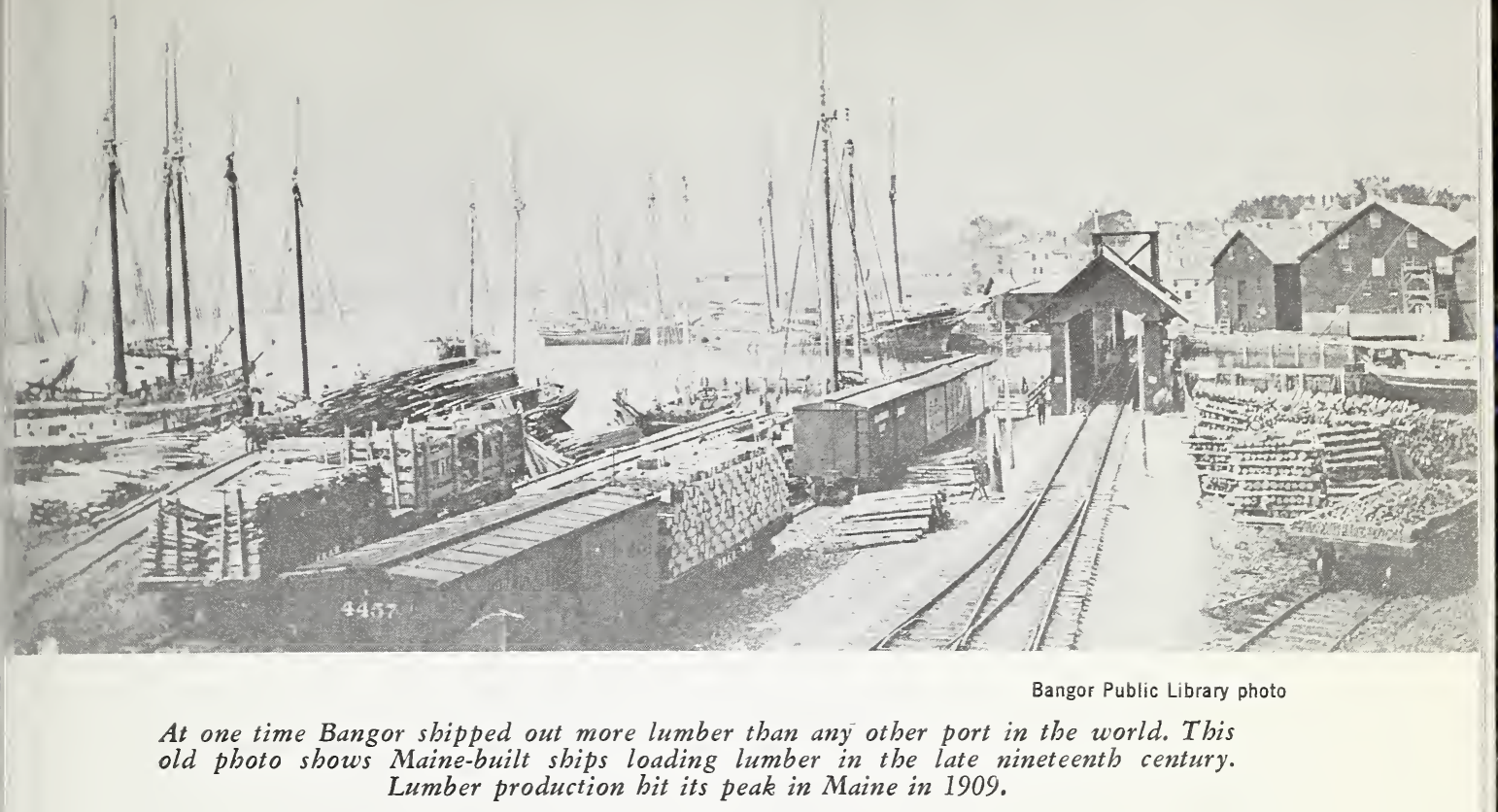

dustry had shifted from the Saco River to Bangor on the Penobscot River. The cutting was still limited to pine and little attention was paid to spruce or other species. During 1842 more lumber is said to have been shipped from Bangor than from any other city in the world.

Maine's lumber production increased steadily to a peak of more than 1.1 billion board-feet in 1909, although its relative position continued to drop (16). The State rated 19th in lumber production at that time.

By 1850 the bulk of the pine had been cut throughout the accessible areas of the State. The loggers then turned to spruce, recutting the same areas where they had formerly cut only pine. The volume of spruce logs coming down the Penobscot River was greater than the volume of white pine for the first time in 1861 . The volume of spruce increased rapidly in the following years. The year 1861 is generally regarded as the end of the pine era in Maine (26), but it was close to the end of the century before the reported cut of spruce lumber for the entire State exceeded that of pine (16). Hardwood lumber was to gain a degree of importance somewhat later, when better roads and transportation became available.

The wood-turning industry had an early start in Maine. By 1848, R. D. Bartlett, of Harmony, had taken out a patent on a lathe for turning handles. One of the first turning mills was established by Captain John Dearborn at Lockes Mills in 1865. This mill manufactured thread spools until 1879, when it was destroyed by fire. The neighboring town of Bryants Pond seized this opportunity to gain an industry. It voted to build Captain Dearborn a new mill and exempt him from taxation for 10 years. By 1860, the U. S. Census listed many turned products manufactured in Maine, including bobbins and spools, spokes and hubs, shoe pegs, clothespins, and rake, shovel, and hoe handles.

Toothpicks are another product of the turning industry. They were first manufactured in Maine by Charles Forster, the "original toothpick man" (25). He had learned the art of whittling out toothpicks by hand while in South America, and, after a period of selling native-pro- 
duced toothpicks to hotels, began the manufacture of toothpicks by machinery at Strong, in 1860. More than 16 million toothpicks were turned out the first year. Toothpicks have been a Maine product for 100 years.

Plywood was being manufactured in quantity by 1897 (1). One large mill was located near St. Croix Lake on the Ashland Branch of the Bangor and Aroostook Railroad. Other plywood mills were operating in Foxcroft and Newport at this time. The Cooper Brothers' Mill in Newport was using basswood for the manufacture of sleigh and carriage dashes and panels and for mirror and picture framing. Four large mills were reported operating in Blaine, Oakfield, Danforth, and Princeton in 1900. These plants used beech, birch, and maple in the manufacture of box material.

The first use of wood for paper-making in Maine took place in 1868 or 1869 in the basement of a sawmill at Topsham ${ }^{2}$. In this operation ground wood

${ }^{2}$ Goode, Robert Donald. The pulpwood industry in Maine. Unpublished thesis, University of Maine Library, Orono, Maine, 1934. was combined with rags to produce 1 ton of paper every 24 hours. Today, the Pejepscot Paper Company has its office on the site of the original paper mill. The first chemical pulp mill in Maine was built in 1872 at Yarmouthville in the town of Yarmouth. It employed the soda process. In 1880 the S. D. Warren plant at Cumberland Mills also began making paper by the same process. Other mills followed at Fairfield, Rumford, Old Town, and Great Works.

In 1880 the Denison Manufacturing Company, in Canton, produced the first paper made entirely from wood. The S. D. Warren Paper Company began experimenting with the soda pulping process in 1875 and subsequently employed this process to pulp aspen in their mill at Coopsecook, in 1880. The Eastern Manufacturing Company built the State's first sulfite mill at South Brewer in 1889, converting slab waste from their sawmill into pulp (6). During the next few months other sulfite mills were established by the Orono Pulp and Paper Company at Orono and by the Cushnoc Fiber Company at Fairfield. This marked the begin-

Maine Dept. of Inland Fisheries \& Game photo

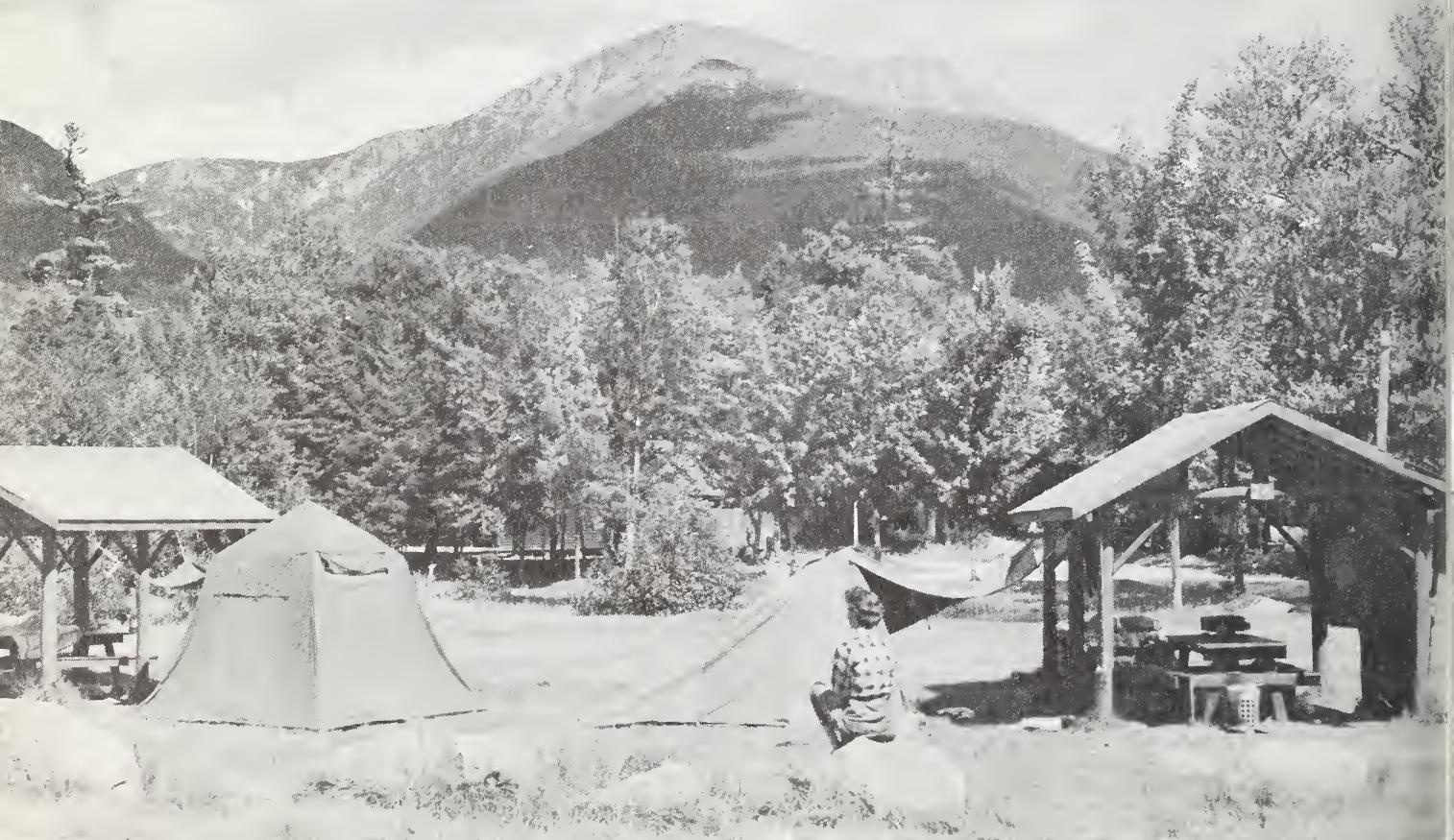


ning of a new industrial era for Maine. The State was at the very forefront of the pulp and paper industry from 1875 to 1900.

Spruce was then and still is the favored pulping species. More recently pine, balsam fir, hemlock, larch, and most of the native hardwoods have also been utilized.

By 1890 Maine led in pulp production, producing nearly one-fourth of the $\mathrm{Na}$ tion's output. Maine continued to lead all other states in pulp production for nearly 50 years. However, with the development of the kraft pulping process in the 1930's, the Southern pines could be made into paper. This development, and other pulping improvements, caused Maine to lose its dominance in the pulp industry. In 1956 Maine held fourth place-behind Washington, Georgia, and Florida. Despite an increase in woodpulp production of nearly 40 percent since 1950, Maine's relative position in this field remains about the same.

\section{Uses of the Forests Today}

$\mathrm{T}$ HE wood-using industries of Maine are concerned mainly with forests as a source of timber; and most of the private owners of forest land in Maine are also interested in the production of wood, because this provides them with a source of income. Yet to the general public the same forests provide many other benefits. Consequently the true value of the forest resource includes not only timber, but also recreation, wildlife, and water-supply benefits. The values of the forest indeed are multiple.

During recent decades, markets for wood products have grown substantially; and in the decades ahead they are expected to grow even larger. In response to this growth, additional permanent manufacturing facilities have been constructed, and the harvest of timber products has increased. In the decades ahead, the same forests will be called upon to supply wood in even greater volumes, as indicated by the recent trend toward more intensive timber management on forests owned by the wood-using industries.

But increases in population and leisure time have, at the same time, created an unprecedented growth in the demand for recreation, fishing, hunting, and other public uses of the forests.

As a result, there is a more urgent need for the multiple-use management of Maine's forests. Multiple use implies management that is designed to produce a combination of values on the same area. Effective multiple-use management can increase the production of all the benefits now being derived from Maine's forests.

Such management will help conserve the productive capacity of the soil and insure water benefits. Well-managed forests help stabilize the flow of streams throughout the year, by storing water when it is most abundant and releasing it gradually. This reduces the hazards of

Recreation is considered an important use of forest land, and both Federal and State governments provide facilities in Maine. This is a State campground. Mt. Katabdin rears its mass in the background. 
floods and assures a more dependable streamflow. Keduced erosion also prevents rapid sedimentation of streams and reservoirs.

Let's look briefly at the recreation and wildlife benefits being produced on Maine's forest lands.

\section{RECREATION}

Recreation is now the State's second largest industry, bringing in an estimated revenue of 272 million dollars in 1958, according to Maine's Department of Economic Development. Many things contribute to make this possible. Certainly one important factor is the natural recreational opportunities present on privately owned forest land. Tourists and residents are permitted to hunt, fish, picnic, and camp on much of the forest land held by private owners.

Timber harvesting has not appreciably changed the recreational value of the forests during the $31 / 2$ centuries they have supplied raw material for the wood-using industries. The possibilities for canoeing in northern Maine are nearly the same as they were 300 years ago. Vast areas in northern and central Maine remain unpopulated - almost as wild as they were when Thoreau visited there in the 1840s.

Maine Dept. of Inland Fisheries \& Game photo

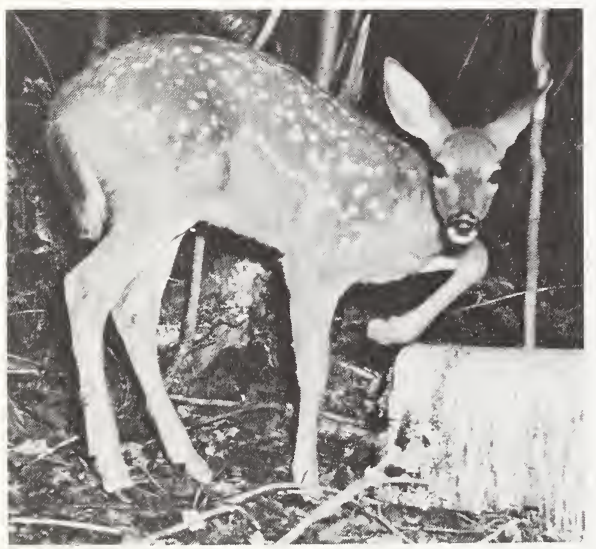

One change has been made: industrial landowners have built many hundreds of miles of improved roads into the forest areas. These roads were built and are maintained to service timber-harvesting operations, but they also provide access by car to many of the State's 2,500 lakes and 3,600 streams. A recent survey by the Maine Department of Inland Fisheries and Game found that 14 of the largest owners have built and are maintaining nearly 1,700 miles of improved roads. More than 85 percent of these roads are open to travel by the public.

Summer homes, hunting and fishing camps, organized camps, private beaches, hotels, and other recreational facilities are scattered throughout the forest areas. In central and northern Maine many of these facilities are on land that is leased from industrial forest landowners, and some are on land leased from the Maine Forest Service. Most of these developments are within areas managed primarily for timber production.

The State Park Commission, Maine Forest Service, U. S. Forest Service, Fish and Wildlife Service, National Park Service, the State Highway Department, and the Appalachian Trail Club all offer public camping, picnicking, and other recreational facilities in Maine. A growing number of privately owned camp and picnic grounds and four winter sport areas are also open to the public.

Maine's public recreational system includes approximately one-third million

Fish and game, another benefit from the timber resource, attract tourists and sportsmen to the forests of Maine.

Winter cover for deer, on left, was reserved from cutting on this pulpwood operation. State game biologists recommend practices like this to maintain bealthy animal and fish populations. 


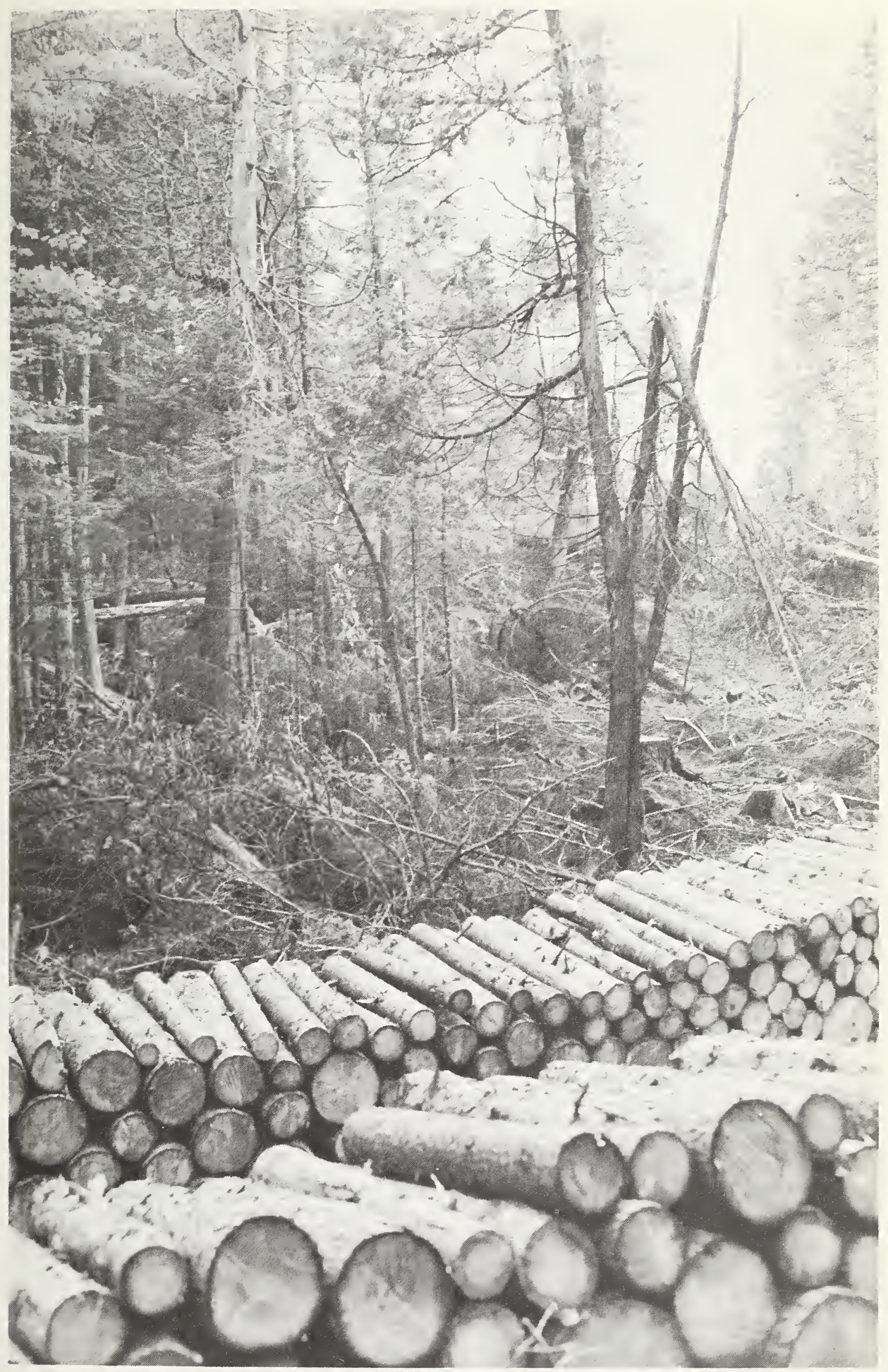

Maine Dept. of Inland Fisheries \& Game photo 
acres of land, mostly forested, that has been designated for public use and recreational purposes (12). Baxter State Park (193,254 acres) in northern Maine is a wilderness park administered by the Baxter Park Authority. About 20,000 acres more are in the 12 state parks and 11 state memorials (13). Over half a million people used these areas in 1958. Four additional state parks, encompassing over 1,000 acres of forest land, are under development.

Acadia National Park on the southern coast of Maine is also dedicated to recreational use. This park contains 28,619 acres of gentle to rugged terrain, most of it covered by forest. It was visited by 816,000 people in 1958.

Some 46,000 acres of the White Mountain National Forest are located in Maine. This land is under multiple-use management for both public recreation and timber production. The Moosehorn National Wildlife Refuge of 22,336 acres is also partially developed for recreational use. Some additional acreage owned by municipalities provides a limited amount of recreational opportunities.

The Maine Forest Service maintains 260 campsites and 89 lunch grounds in the Maine Forestry District (10). Many of these are located in remote forest areas, on land leased without charge from private owners. A sample count shows that more than 100,000 people used these facilities in 1958. The State Highway Department also maintains more than 200 roadside picnic areas, many of them with facilities for overnight camping (11).

\section{WILDLIFE}

The words forest and wildlife have become almost synonymous in this country's great exodus to the outdoors. Few people hear the word forest without associating it with wildlife - the fish and game that are natural products of woodlands. According to the National Survey of Fishing and Hunting (20), 7 percent of the people in New England hunt, and 13 percent fish. The average hunter spends about $\$ 92$ and the fisherman $\$ 79$ annually for licenses, travel, accommodations, and equipment. These expenditures mean income for Maine's people.

Maine's inland fish and game are produced largely within the 87 percent of the State's land area in forests. Most of these lands were acquired and are managed for timber products. Yet they produce an abundance of wildlife for the enjoyment of the public.

Maine's forests are estimated to cortain 180,000 wintering deer, 3,000 moose, and more than 7,000 bear, plus an abundance of small animals, game birds, and fish. This resource is a prime attraction for tourists, and a source of food and sport for those living in the State.

Approximately 256,000 resident and 130,000 non-resident hunting and inland fishing licenses were issued during fiscal year 1958 (8). During the same period 1,600 trapping licenses were issued. By planned harvesting of wildlife, under the recommendation of game and fish biologists, vigorous and healthy animal and fish populations are maintained.

With 99 percent of the State's forests in private ownerships, most management practices to favor game must be carried out on private lands. Some progress is being made in this direction. An increasing amount of industry-owned forest land is being managed to produce more game. Some 100,000 acres of commercial forest along the United States side of the St. Croix River have been designated for multiple-use management for recreation, wildlife, and timber by the Eastern Pulp Wood Company. The industrial owners are dedicating an equal area to this use 
on the Canadian side of the St. Croix. Picnic and camp areas have been located at three sites on the American side and more are planned. Present plans are to allow the public virtually unrestricted use of company-owned roads, and to permit hunting and fishing over the entire area.

Twenty-five winter deer yards located within industrial forests in northern Maine are now managed in such a way that winter protection and food for deer is provided. In other areas, timber harvesting is planned to meet wildlife and recreational needs, including the reservation of woodland strips along streams and lakes. This cooperative program be- tween the landowners and the Maine Department of Inland Fisheries and Game is directed toward maintaining a healthy deer herd.

Another wildlife program involves the seeding of abandoned log roads with clover and grasses to provide more food for grouse in remote woodland areas in northern Maine. More than 80 miles of $\log$ roads treated in this manner have materially increased the harvest of grouse without seriously depleting the future breeding stock. Such forest practices also mean less erosion of woods roads, and thus some clearer streams and lakes in Maine.

\section{The Wood-Using Industries}

$\mathrm{B}$ ESIDES producing other values, forests serve as a factory for producing wood. They derive a large part of their value from the use people make of this wood. If the wood produced by the forest is not utilized, society loses these values.

Today timber is probably the most valuable single product of Maine's forests. Her forests thus can be valued mainly according to the amount and type of timber products that they yield. In Maine, pulpwood and sawlogs account for 90 percent of the timber use, so they are the principal measure of forest values.

The annual cut of lumber and pulpwood in Maine reached a 30-year peak in 1956. For that year the Maine Forest Service reported an output of 550,000,000 board-feet of lumber, veneer, and cooperage, and 2,700,000 rough cords of round wood and chips for pulpwood (14). As a result of the nation-wide business recession, the pulpwood cut was lower in 1957; it remained low in 1958 as pulp companies reduced woodyard inventories that had accumulated during the slack period.

The 1958 cut for all products amounted to 242 million cubic feet, or 3.0 million cords. ${ }^{3}$ This volume includes 371,000 rough cords of logging residues that were left in the woods. Softwood species $^{4}$ made up approximately 70 percent $(2,112,000$ cords $)$ of the total cut, hardwoods the remainder. Wood for lumber and pulp accounted for 90 percent of the total cut for all products.

\footnotetext{
${ }^{3}$ For the convenience of the reader, cubic-foot volumes have been converted to rough cords of 80 cubic feet of solid wood. Thus cubic-foot volumes may be computed by multiplying the number of cords by 80 . Definitions of these and other terms used in this report will be found in the Appendix.

"The terms "softwood" and "hardwood" do not necessarily refer to the actual hardness of the wood. In general, softwoods are those tree species that have needles and are green throughout the year (larch is an exception). Hardwoods are broad-leafed trees; they usually lose their leaves each fall and grow new ones in the spring.
} 
Three-fourths of the total volume cut was in sawtimber-size trees - hardwoods 11 inches and larger at breast height and softwoods 9 inches and larger. The remaining cut was from poletimber-size trees (trees below sawtimber size but not less than 5 inches in diameter). On a volume basis, the total cut from growing stock was distributed as follows:

$\begin{array}{lr} & \begin{array}{c}\text { Million } \\ \text { cords } \\ \text { Softwood sawtimber trees...... }\end{array} \\ 1.71 \\ \text { Hardwood sawtimber trees..... } & .51 \\ \text { Softwood poletimber trees..... } & .40 \\ \text { Hardwood poletimber trees..... } & .40\end{array}$

Although timber was cut in every county in Maine during 1958, more than one-half of the volume was cut in the four northern counties. Aroostook County led all others in both pulpwood and sawlog production. But in relation to the forest volume, timber was cut more heavily in the southwestern counties.

During the past decade, there has been a change in the proportions of timber species cut. The proportion of spruce and fir cut for pulp decreased 5 percent to the present 65 percent of total pulpwood output; the hardwood proportion increased 5 percent. White pine continues to be the

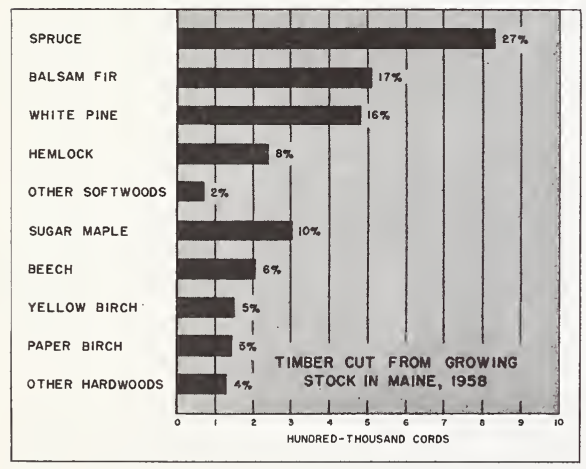

Timber is the most valuable product of Maine's forests. In 1958 spruce and fir together accounted for more than 40 percent of all the timber cut. principal species cut for lumber, but its relative importance has declined from 50 percent of the total to about 44 percent. The proportions of spruce and hardwoods cut for lumber increased accordingly.

\section{PULPWOOD}

Pulp and paper is Maine's most important industry in value of manufactured products. The pulp mills require more raw wood material than do all other wood-using industries combined. At the end of 1958 the State's 28 pulp mills (19 plants) had a 24-hour capacity of 5,995 tons - 7.3 percent of the Nation's total (21). Only three states - Florida, Georgia, and Washington - have a greater plant capacity for producing pulp.

Paper and allied products accounted for 27 percent of the value of all products manufactured in Maine in 1958, a total of some 364 million dollars (9). If the lumber and wood industry (fifth largest manufacturing industry) is included, the combined forest-products industry would account for 35 percent of the value of all manufactured products.

Maine's pulpwood production amounted to nearly 1.7 million cords in 1958. Expressed in cubic feet, this was 57 percent of the total timber-product output. This excludes 35,255 cords of plant residues that were used for pulp during the year. These residues (principally from softwood species) consisted mostly of slabs, edgings, trimmings, and unmerchantable boards resulting from the sawing of debarked logs.

For many years hardwoods were not used much for paper making. But with the development of new pulping processes, they now make up about 22 percent of the pulpwood harvest in Maine. In 1958 the cut of hardwood pulpwood 


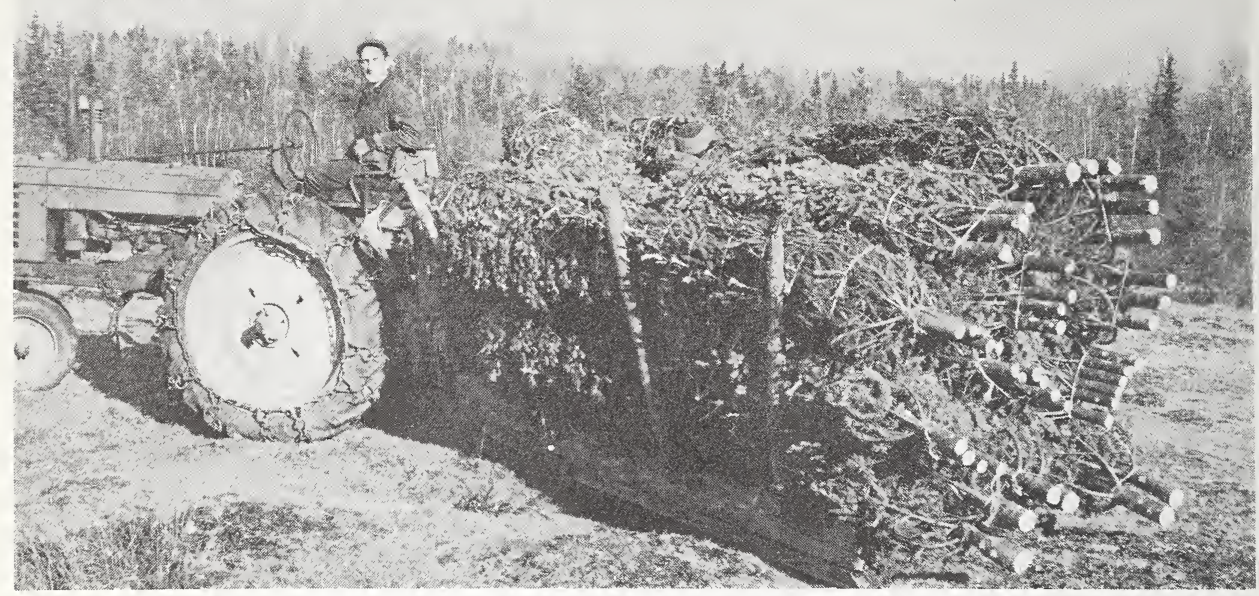

Maine Forest Service photo

\section{Another crop harvested annually from Maine forests - Christmas trees.}

Both softwoods and hardwoods are used by the lumber industry. Hardwood lumber is used for assembled furniture, furniture blanks, toys, novelties, pallets, cabinet work, thread spools, dowels, woodenware, toboggans, and many other items. Softwood lumber is used for construction; small quantities go into millwork, boxes and crates, boats, furniture, fencing, and other items (7).

\section{OTHER TIMBER PRODUCTS}

Ninety percent of the timber cut from Maine's forests in 1958 was used to manufacture pulp and lumber. The remaining 10 percent was used in the production of veneer, fuelwood, and other products. In 1958 there were 341 Maine firms that manufactured wooden items other than construction lumber and pulp and paper. Some 360 different wood products are manufactured in the State.

Five percent of the timber cut was used to manufacture veneer. Production by the veneer industry has declined in recent years: only 43 million board-feet of veneer logs and bolts were used in 1958. About twice this amount was used 20 years ago, but since then supplies of high-quality veneer logs have declined. Then too, imports of hardwood plywood from abroad have increased greatly; and more than 97 percent of the timber cut today for veneer use in Maine is hardwood-largely paper birch, yellow birch, and sugar maple.

The veneer industry in Maine consists of eight veneer mills and three plywood plants. The veneer mills produce thin sheets of wood by either turning short logs or bolts against stationary knives on rotary lathes or by slicing off thin sections from specially prepared blocks or cants. Stamped from this veneer are astronomical numbers of small wooden products known as flatware - popsicle sticks, tongue depressors, cocktail forks, flat spoons, glue paddles, and applicators.

Plywood is another product made from veneer. Plywood is made from three or more layers of veneer glued together in large sheets. Hardwood plywood is used for furniture, cabinetmaking, wall paneling, doors, toys, boats, and many items for which an attractive, strong, durable wood is needed.

A large portion of the veneer logs cut in Maine in 1958 were exported to other states and Canada for processing, and a small quantity was cut for shipment from Canada to England.

Four percent of the timber cut in 
Maine in 1958 was used for fuel. At one time wood was the only fuel available for cooking, heating, and steam plants. Now electricity, coal, oil, and gas have replaced wood for most of these uses. The 1958 use of fuelwood amounted to 264 thousand cords, almost entirely hardwood. About 21 thousand cords were from the tops, limbs, and cull sections of trees and 108 thousand cords from plant residues. Only about half the fuelwood (135 thousand cords) was cut from growing stock.

The timber cut. for all other products amounted to about 1 percent of the total cut. Included in this category are piling, poles, posts, hewn ties, wooden fencing, chemical wood, lobster traps, fish weirs, and other miscellaneous items.

Some cedar is used in making slack cooperage, principally barrels for potatoes, fish, poultry, and vegetables. Some
$11 / 2$ million board-feet were cut for this purpose in 1958. Small quantities of cedar are also used in the manufacture of shingles.

The Maine forests contain an abundance of fir, which is preferred for Christmas decorations. Some spruce is also cut for this use. Their harvest has been an annual source of Christmas funds for the Maine people for many years. In 1958 the Christmas-time harvest included 855,000 trees, 6,900 bundles of softwood boughs, and 271,000 wreaths (24).

All in all, the forests of Maine provide raw material for the wood-using industries; they are the base for a growing recreation industry; and they are instrumental in the conservation of soil and water. In short, Maine's forests are a cornerstone of the state economy. Their productivity affects the welfare of everyone in the State.

\section{The Timber Resource}

$\mathbf{N}^{\circ}$ OW let's consider the present condition of Maine's forests. How much timber is there in Maine that can be used for making paper, lumber, veneer logs, and other products? What did the Forest Survey reveal?

In discussing the timber used by various industries, we referred to sawlogs, veneer logs, and pulpwood. These terms refer to tree segments that have been cut for a specific product. But in conducting an inventory of timber we must measure trees. And although the inventory must be made in terms of the forest resource's usefulness for specific products, there is no sure way of determining what product or products will be cut from each tree. For example, a tree 16 inches in diameter may be well suited to making pulpwood, sawlogs, one or more veneer bolts, or some combination of these products. How then should we measure this tree?

If we measured the standing timber so as to estimate how much pulpwood could be cut from it, the information would have greatest interest for those who operate pulp mills. But this would leave sawmill operators with only a very poor idea about how much of the timber inventory is suitable for lumber manufacture.

To solve this dilemma we classified the trees twice, using specifications for the two major products that are being cut from Maine's timber - lumber and pulpwood.

First we looked at the trees to determine their suitability for making sawlogs and lumber. Measurements were taken to 


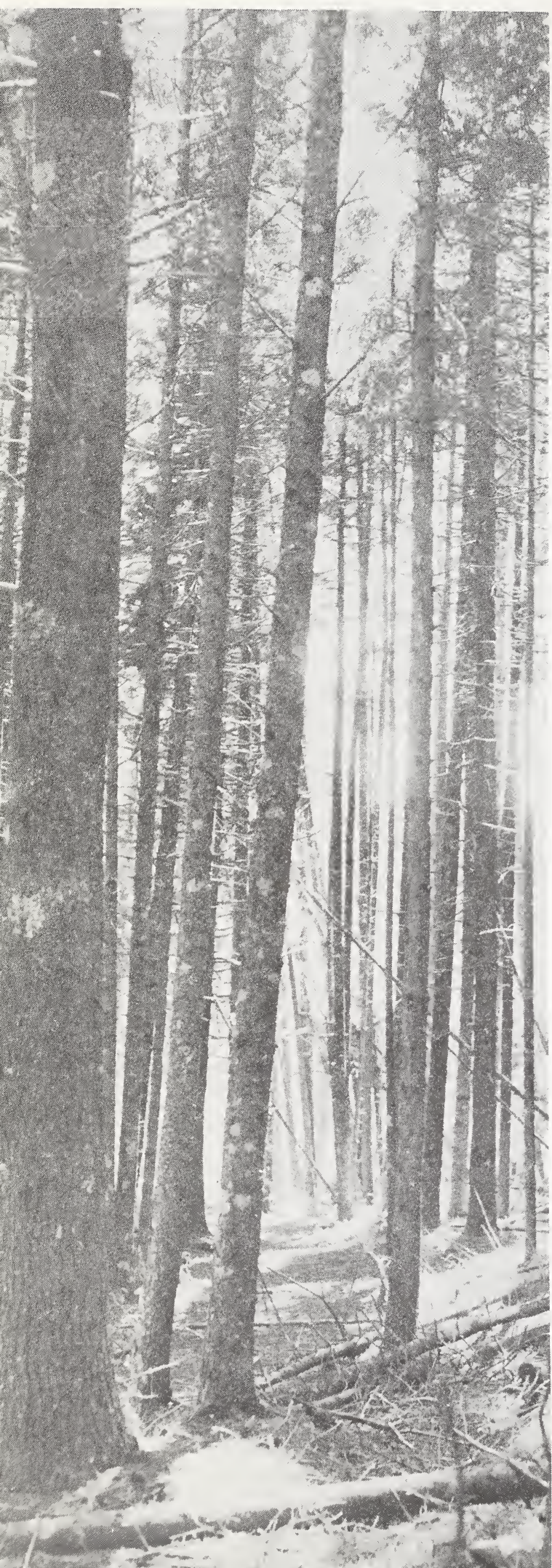

estimate each tree's volume in terms of board-feet. The sawtimber stock thus consists only of the board-foot volume of those trees that met minimum size and quality specifications for making sawlogs.

Poletimber-size trees were classified, and their volume is given in cubic feet and cords. As they add growth, poletimber trees are expected to become sawtimber. The cubic-foot volume of wood in both sawtimber and poletimber trees is called growing-stock volume in this report. Trees 5.0 inches and larger that do not meet minimum specifications for either sawtimber or poletimber are referred to as culls.

Next our field crews completely reevaluated each tree to see if it met the minimum specifications for a pulpwood tree. If it did, the tree was also classified as a pulpwood tree; and an estimate was made of the volume, in cords, of pulpwood that could be cut from it. This decision was independent of whether it was a sawtimber cull. Thus, this report contains three kinds of volume estimates:

- The volume of sawtimber, in board-feet: an estimate of the volume of lumber that could be cut from all trees that are suitable for making sawlogs.

- The volume of growing stock, in cubic feet: an estimate of the present volume of current and potential sawtimber trees.

- The volume of pulpwood trees, in cords: an estimate of the volume of pulpwood that could be cut from growingstock and nongrowingstock trees that meet pulpwood-tree specifications.

Note that these three estimates are merely different ways of inventorying the same trees. A great deal of the same volume appears in all three estimates. For example, all sawtimber volume is in-

\section{A typical spruce stand, a valuable source} of both pulpwood and lumber. 


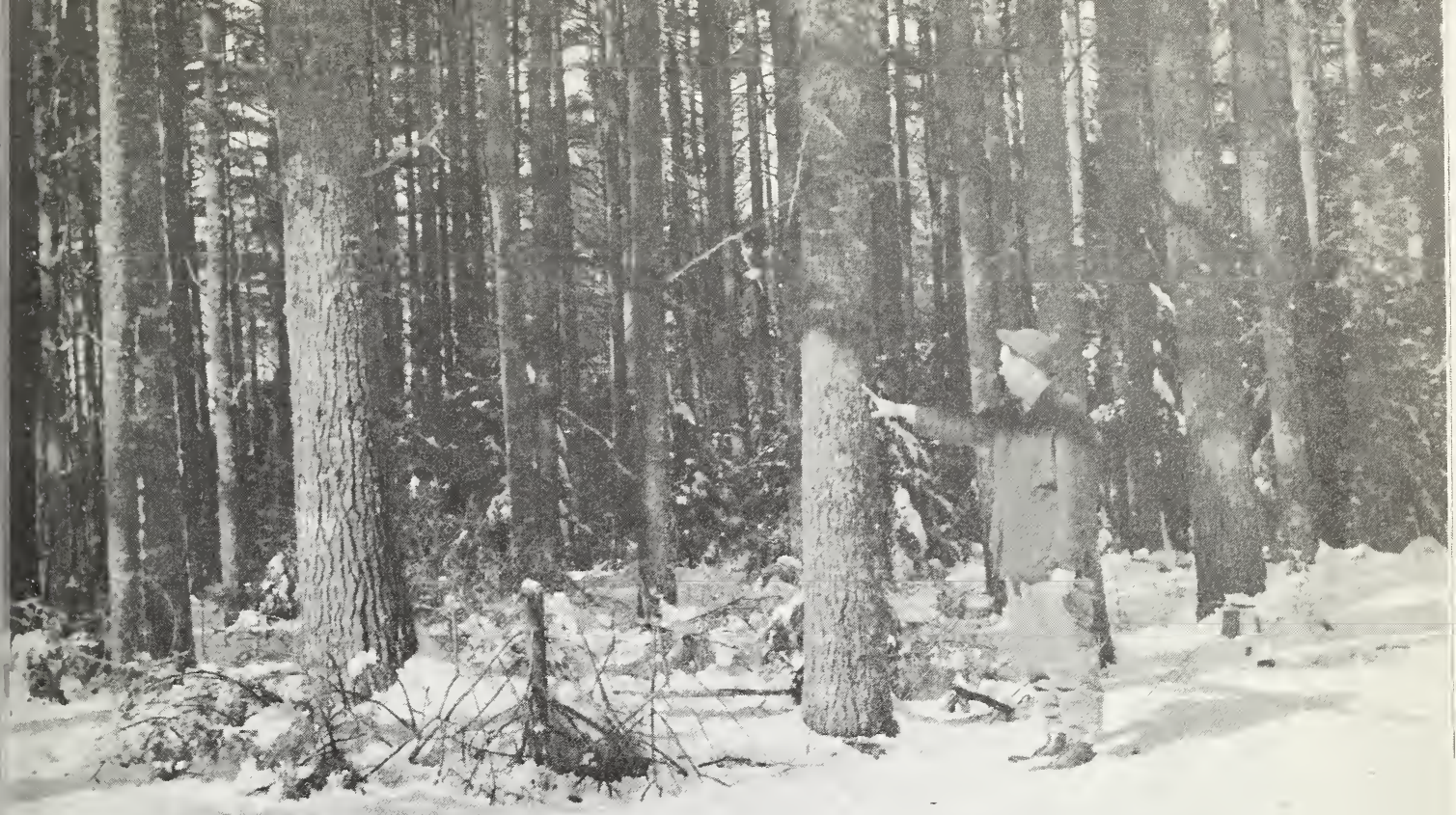

Maine Forest Service photo

A typical second-growth white pine stand. This stand is growing enough wood on each acre every 10 years to build a 5-room bouse.

cluded in the growing-stock estimates, and most of it also appears in the pulpwood estimates. Thus one must not add a pulpwood estimate to a sawtimber estimate, for this would be double-counting.

\section{MILLION CORDS OF PULPWOOD}

Pulpwood in Maine is normally harvested in 4-foot sections from the boles of trees. Trees that are suitable for cutting into pulpwood are called pulpwood trees. And in this inventory, a pulpwood tree was defined as any tree of commercial species that is at least 5 inches in diameter at breast height and meets certain other specifications, such as having at least 8 continuous feet of its stem usable for pulpwood.

The pulpwood estimate consists of the net volume of pulpwood in pulpwood trees. Thus, in terms of pulpwood, the 1958 inventory of timber in Maine amounted to $205,500,000$ cords.

This wood is distributed among many species, but spruce and balsam fir are the most abundant. Spruce accounts for about 22 percent and balsam fir for 20 percent. They are followed in order by white pine, northern white-cedar, and red maple. All hardwood species combined make up onethird of the volume suitable for pulpwood.

Not all the wood in trees cut for pulpwood is used for pulping; some of it is uneconomical to use and some is not good enough. Limbwood, very knotty wood, and pieces less than 4 inches at the small end are generally not used. Neither are pieces that contain excessive rot or charred wood. These would cause weak spots, holes, or discoloration in the finished paper, and would require excessive 
amounts of bleaching chemicals in the paper-making process. Also excluded are pieces that are excessively hollow and those that have wire or nails imbedded in the wood.

Of the total volume suitable for pulping, about 94 percent is in trees that are currently or prospectively suitable for sawtimber, and 6 percent is in trees that would be called cull for sawtimber use.

Nearly 60 percent of the pulpwood volume is found in stands that have 15 cords or more per acre. These heavier stands, which are more economical to harvest than thinner stands, occupy about one-third of the commercial forest land area:

\section{Volume-per-acre Thousand Million class acres cords}

Less than 5 cords per acre 4,003 9.1

5 to 15 cords per acre. . $7,628 \quad 76.9$

More than 15 cords

$\begin{array}{ccc}\text { per acre } \ldots \ldots \ldots \ldots & 5,538 & \frac{119.5}{205.5}\end{array}$

\section{BILLION BOARD-FEET OF SAWTIMBER}

Sawtimber volume is measured in board-feet, that is, the estimated volume of lumber that could be cut from logs and sawtimber trees. A board-foot is a section of lumber 1 foot square and 1 inch thick before planing, or its equivalent.

As a basis for measuring sawtimber volume, we used the International 1/4inch $\log$. rule for softwood trees 9.0 inches in diameter and larger and hardwood trees 11.0 inches in diameter and larger. Trees on sample plots were recorded by species, diameter at $41 / 2$ feet above ground (diameter at breast height $=$ d.b.h.), and height in 16-foot logs. Top log can be 8 feet long, although sawlogs are cut in various lengths, usually

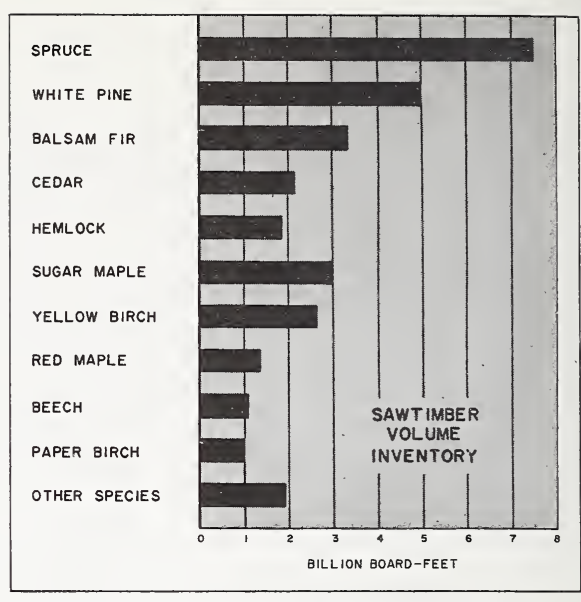

About 65 percent of Maine's sautimber volume is in softwoods. White pine accounts for about 15 percent of the total volume.

in multiples of 2 feet, such as 10, 12, 14, and 16 feet. Sixteen feet is a common length, and logs are seldom cut longer than this in Maine.

The net volume of standing trees that meet minimum specifications for sawtimber amounts to 30 billion board-feet. Although about three times more lumber is now being cut from white pine than from any other species in Maine, spruce leads all species in standing sawtimber volume - about $71 / 2$ billion board-feet, or 25 percent of the total. The volume of white pine sawtimber amounts to 5 billion board-feet. The white pine is found principally in the southwestern part of the State. All hardwood species combined make up almost 35 percent of the total.

But quantity is only one measure of the sawtimber resource. Quality is another especially important consideration. Timber quality is expressed in terms of $\log$ grades. For both hardwoods and white pine there are three standard lumber log grades; and for hardwoods there is an additional grade: tie and timber logs. 
Tree sections that do not meet the minimum specifications for any of these are considered culls for lumber manufacture.

Over the long period of time since timber cutting began in Maine, the proportion of high-quality sawlogs has decreased. Only 12 percent of the white pine sawtimber volume is now found in grade 1 logs. Of the hardwood volume, about 17 percent is in grade 1 logs.

There are several reasons why there is so little high-quality sawtimber in Maine. When the original forests were cut over, only the tallest, straightest, and finest trees were taken. In subsequent cuttings the larger and better trees usually made up most of the cut. The trees left were often defective and of poor quality. Destructive forest fires, insects, and diseases have also reduced the quality of trees that escaped being killed. A large part of today's sawtimber volume is in relatively small trees, and smallness also limits quality. About 44 percent of the boardfoot volume now is found in trees less than 14 inches in diameter. Trees below this size do not produce logs large enough to meet grade 1 requirements.

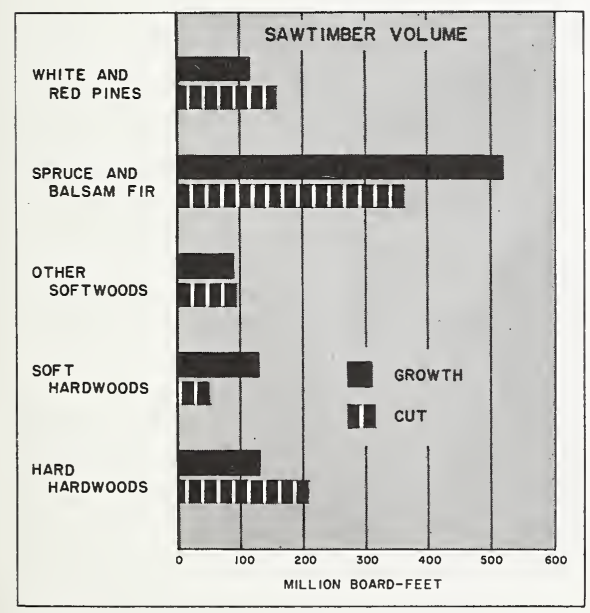

Relationships between growth and cutting of sawtimber-size trees.
Concentration of sawtimber volume is another important consideration. If all other factors were equal, logging would cost less in timber stands that have large volumes per acre. A stand that has only a small volume per acre is expensive to cut. Very few woodsmen would be willing to cut sawtimber in stands of widely scattered trees. In our inventory, if a stand does not have at least 1,500 boardfeet of sawtimber per acre, it is called either a poletimber stand or a seedlingand-sapling stand rather than a sawtimber stand.

Sawtimber stands occupy some 6,777,000 acres - about 40 percent of the commercial forest-area in the State. These stands contain about 80 percent of the sawtimber volume. The other 20 percent of the sawtimber volume is distributed within poletimber stands, seedling-andsapling stands, and poorly stocked areas.

\section{CURRENT TIMBER GROWTH}

The date of the timber inventory in Maine is January 1, 1959. This inventory will change from one year to the next according to how much timber is cut and how fast the timber grows. Growth information was obtained in the Forest Survey by interpreting increment cores. Sample trees on forest-survey plots throughout the State were bored for small cores of wood showing annual growth rings. Measurements of these were used in the calculation of net annual growth.

Net annual growth is composed of several parts, which must be explained before growth figures can be properly understood. Trees that already meet survey specifications grow in diameter and height. Their increase in volume is added to the timber inventory. Other trees are designated as ingrowth if they reach specified minimum size during the yearfor example, trees less than 5.0 inches at 
the beginning of the year that become larger than 5.0 inches during the year are ingrowth. Also, some trees die during the year; their volume is negative growth, so it is subtracted from the inventoried volume. Growth is thus computed as follows: Net annual growth $=$ (increases in the volume of trees that are already part of the timber inventory) + (volume of ingrowth trees) - (volume of trees that die).

Net annual growth of Maine's growing stock in 1958 was 7,176,000 cords. Spruce and fir accounted for about 55 percent of this growth, all other softwoods 15 percent, and hardwoods 30 percent. The volume of poletimber is greater than that of sawtimber. This is perhaps one reason why growth is larger for the poletimber class in both softwoods and hardwoods:

NET ANNUAL GROWTH

Softwoods Hardwoods

(thousand (thousand

cords)

Sawtimber

2,274

cords)

Poletimber ......... 2,775

760

1,367

Net annual growth of sawtimber in Maine in 1958 was $962,600,000$ boardfeet. Softwood species made up about three-fourths of this total. More than onethird of the gross board-foot volume (growth on inventory plus ingrowth volume) was lost in trees that died.

NET ANNUAL SAWTIMBER GROWTH

$\begin{array}{cc}\text { Softwoods } & \text { Hardwoods } \\ \text { (million } & \text { (million } \\ \text { board-feet) } & \text { board-feet) }\end{array}$

Growth on inventory... $476 \quad 174$

Ingrowth $\ldots \ldots \ldots \ldots+586+230$

$\begin{array}{llrr}\text { Gross growth } & \ldots & 1,062 & \\ \text { Mortality } \ldots \ldots & \ldots & -351 & \\ & & -152 \\ \text { Net annual growth } & 711 & 252\end{array}$

\section{To Increase the Benefits}

\section{$\mathrm{T}$} HOUGH the forests of Maine now support the State's largest industry, and seem likely to continue doing so, they are producing at a rate much below their potential. Increased timber production would mean more and possibly better material for forest industries. This might lead to expanded production and greater manufacturing income, increased employment and wages, additional income to forest-land owners, and an expanded tax base.

But the results of improved forest practices do not develop overnight. Many years must pass before today's improved forest management will appear as bigger and better-quality woodpiles at the sawmill, pulpmill, or manufacturing plant. More intensive management must start before shortages are actual. Therefore it is wise to consider such practices now, even though Maine's forests are now growing more wood than is being cut. An increased demand for raw material through improved markets and expanded manufacturing facilities is expected. And a heavy loss of standing timber by fire, wind, or forest pests could quickly reverse the present trend toward larger timber volumes.

The forests of Maine could be made more productive and useful in several ways. They could be managed so as to grow a greater volume of marketable wood. They could, through judicious forest practices, produce wood of a higher quality and of a more desirable kind. And they could be operated in a way that 
would prevent the indiscriminate cutting of immature trees or stands but at the same time provide for the orderly harvest of mature trees before they become defective or die. Losses through fire, insects, diseases, and climate could be held to a minimum. Then too, management and sarvesting costs could be reduced and the volume of usable products could be increased through more efficient utilization of the forest crop.

Many different measures are possible to achieve these objectives. Six appear to be of particular importance: greater utilization, improved cutting practices, more timber-stand improvement, increased protection, accelerated planting of idle and understocked lands, and additional forestry research.

\section{GREATER UTILIZATION}

Improved utilization practices could increase benefits from the timber resource in two ways: first, by increasing the amount of timber products harvested; second, by more complete and efficient use of the cut trees.

\section{INCREASING THE TIMber HARvest}

Since timber must be harvested to be used, an increased timber harvest would probably mean that Maine's forests would be more useful - if this harvest could be sustained. But excessive harvesting can lead to a serious reduction in growing stock, the timber capital that is necessary to produce high-value timber products.

Let's briefly examine the present trend of the standing timber in Maine. If net timber growth exceeds timber cut, then the inventory is increasing, and, either now or eventually, a heavier cut could be sustained.

In 1958, the total cut of both hardwood and softwood species amounted to about 43 percent of the growth. As a re- sult, Maine's forests were growing more than twice as much wood as was harvested: growth amounted to 7.2 million cords and cut to 3.0 million cords. The difference, some 4.2 million cords of growth, was added to the growing-stock volume. Although the total volume is increasing, the amount of high-quality timber is not increasing as rapidly.

An additional 3.4 million cords (about one-third of gross growth) is being lost through mortality each year. Thus a greater volume of trees died during 1958 than were harvested. Improved accessibility and shorter cutting cycles could substantially reduce the mortality losses and provide a greater net growth available for cutting.

The cut of sawtimber trees of all species amounted to 81 percent of the total growth in trees of this class (softwoods 82 percent and hardwoods 80 percent). But the difference between growth and cut in sawtimber varies considerably among species groups. The cut of hardhardwood sawlogs (mainly sugar maple, yellow birch, white birch, and beech) was almost 25 percent more than the amount added by growth. The cut of white and red pine sawlogs exceeded growth of these species by 41 percent.

From this it is evident that the main increase in volume is in poletimber-size softwood trees, in the spruce-fir, sprucefir - hardwood, and hardwood - spruce - fir types. In fact, the cut of poletimber trees was only about one-fifth as much as the growth in this class-amounting to about 15 percent for softwoods and 30 percent for hardwoods. Some increase is also occurring in certain soft-hardwood types, such as the aspen type.

When the cut is less than growth, the difference is not lost but is added to the timber inventory-the growing stock. Up to a point, this improves the forest stands 
and provides a bigger and better base for future growth. In some cases this is highly desirable; in others it results in increased loss of timber volume through mortality or increased cull as trees become overage and defective and either die or develop rot and other defects. Some trees, like balsam fir and aspen, are short-lived; they die or deteriorate rapidly after reaching maturity.

Though there are opportunities in Maine for increasing utilization through a larger harvest of timber, careful consideration must be given to the location of the increased cut and to the species involved.

The forest survey shows that $21 / 2$ million acres $(1 / 7$ of the total commercial forest land) have less than $11 / 2$ cords of growing stock per acre. And about 31/2 million acres ( 43 percent of all stands classified as poletimber) have an average stocking of only 5 cords per acre. Clearly, growth must exceed cut in all such stands.

\section{Complete Utilization}

Utilization of the forest resource can be a wasteful business. At times more volume is left in the woods in tops, branches, and unmerchantable material than is utilized. With good utilization, each tree harvested is cut into the highestvalue products possible. This in turn increases the timber yield and income and gives the same result as increasing the growth rate of the forest stand. In Maine, as elsewhere, the degree of utilization is also influenced by markets, accessibility, species, quality of trees, supervision given the cutting crews, and management policies.

Pulpwood cuttings utilize material in 4-foot lengths down to 4-inches in diameter, ordinarily giving reasonably efficient utilization of the cut trees. Reasonably good utilization is generally attained with softwood trees in Maine, but greater use of the associated hardwood species is needed. Exceedingly large volumes of potential hardwood products are often left after the conventional pulpwood operation, generally for good reasons: the dense hardwoods do not float and cannot be water-driven to the mill with the lighter softwoods; hardwoods are heavy and expensive to haul for long distances; the current market for hardwood pulpwood is limited to about 25 percent of the total pulpwood consumption, and the present mill price for hardwood pulpwood is relatively low. Cedar and aspen also are often left for lack of adequate markets.

Again the importance of a well-developed network of roads is evident. Better roads mean cheaper logging, and lower logging costs are important to achieving more complete utilization.

\section{IMPROVED CUTTING PRACTICES}

Timber from Maine forests is usually barvested according to one of several 'methods of cutting, including clearcutting, shelterwood cutting, diameter-limit cutting, or a variation of selection cutting.

Clearcutting is a method of harvesting timber that is designed to remove all of the merchantable trees in one operation. This method is commonly used when cutting remote areas to which the timber operator can not or does not plan to return for many years. It is also a practical method of reproducing those tree species that require full sunlight to become established and grow well. Some disadvantages of clearcutting are the long period of time between cuttings, the untimely removal of many vigorous and fast-growing trees, mortality of seedlings and saplings during and after logging, and usu- 
ally a lower quality of harvested products.

Shelterwood cutting is a method of removing mature timber in a series of cuttings extending over a number of years. Cutting according to this method is usually divided into three or more phases, including a preparatory cutting, a seed cutting, and a final or removal cutting. This method of cutting mature stands is used with species that require partial to full sunlight to become established and grow.

Selection cutting is a method by which trees are selected for harvesting on the basis of their vigor, spacing, species, and size. The method has several variations: the two most common are single-tree selection and group selection - removing single trees or groups of trees at relatively short intervals of 5 to 20 years. Selection cutting is an ideal method to use on species that become established and grow under partial or full shade. When properly employed, this type of cutting usually leaves a well-stocked stand of the most vigorous, fast-growing, and wellformed trees in all size classes. Selection cutting is an ideal method for the management of small woodlands where the owner is interested in cutting at fairly frequent intervals.

A diameter-limit cutting is the harvest, in one cut, of all trees above a specified diameter. By having different diameter limits for different species, the cuttings can be modified to remove certain species and leave others. The diameter-limit cutting is a sort of compromise between clearcutting and some type of partial cutting. Thus it may have some of the advantages and disadvantages of clearcutting, shelterwood cutting, and selection cutting in some degree.

Most foresters in Maine favor some type of selection cutting over the other cutting methods. However, each method has certain advantages and disadvantages according to the species, forest conditions, product objectives, and needs of the landowner. And because of these many factors that must be considered, it is advisable that the services of a forester be utilized in the management and harvesting of forest stands.

\section{TIMBER-STAND IMPROVEMENT}

Timber - stand improvement includes such measures as removal of undesirable trees, thinning, and pruning. These measures are used to increase net growth and to improve the quality of existing stands.

Trees may be undesirable because they are too crooked, too limby, or too defective to be converted into timber products. They may be of a species that has a low market value. These trees occupy space in the forest; yet they contribute little or nothing in the way of usable timber. Removing them provides additional space for more useful trees.

There is considerable opportunity in Maine to improve the forest yields by removing or deadening cull trees, particularly the worthless hardwoods left after cutting in softwood stands and mixedwood stands. Some cull trees may persist in these stands for many years. Some become huge wolf trees, occupying a great deal of valuable growing space. Over a period of time these trees are responsible for a sizable loss in timber production.

The need for removal of cull trees is perhaps most apparent in hardwood stands of central and southern Maine. These lands have been cut more often, and some of them more unwisely, than forests in other sections of the State. Diseases, insects, and climatic factors have also reduced the productivity of these forests. 


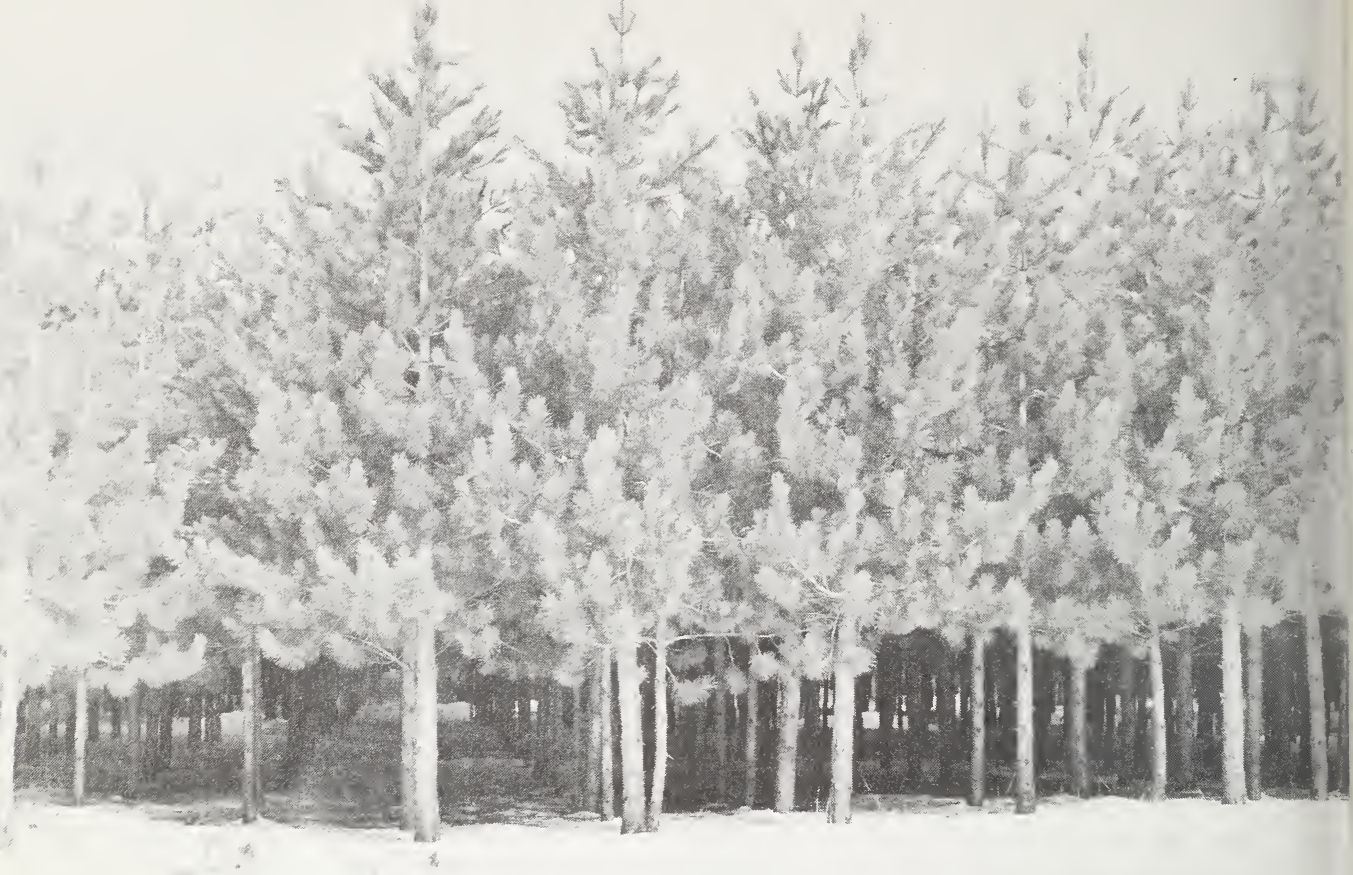

Maine Forest Service photo A pine plantation ready for thinning, a practice that increases growth and improves tree quality. The pulpwood harvested in thinning this plantation should more than pay the costs of the operation.

Unwanted trees can be removed by cutting, or they can be killed by girdling ${ }^{5}$ or by application of chemical silvicides to their trunks or foliage. In some instances undesirable brush and small worthless hardwoods can be eliminated through aerial application of silvicides. This method is particularly useful for releasing pine seedlings that are found on some of the brushy, previously burned areas in southern Maine.

Thinning involves cutting some of the less promising trees in crowded stands. This provides more growing space for the residual trees and allows them to grow more rapidly and reach maturity sooner. This way the productive capacity of the soil used to concentrate growth on

\footnotetext{
${ }^{\circ}$ Severing the cambium, a thin layer located just under the bark, by removing a narrow but continuous strip of bark around the circumference of the tree.
}

the higher quality trees and on trees of the most desirable species.

Thinning could be applied to many white pine stands and balsam fir thickets in Maine. These often contain many times more trees than are needed, and the trees go through a long period of extremely slow growth before reaching merchantable size. These stands would benefit from thinning at almost any stage of their development.

Pruning is another timber-stand-improvement practice that could increase the future value of softwood timber stands. Pruning white pine or red pine crop trees will produce a greater volume of clear lumber at harvest time.

\section{INCREASED PROTECTION}

As every resident of Maine knows, forests are subject to destruction by fire, insects, and tree diseases. A completely 
effective protection program would hold losses from these to a minimum.

Historically, wildfires have been the greatest enemy of Maine's forests. Serious fires have occurred in the past and are a constant threat, particularly in the southern section of the State and on areas of heavy slash created by cutting in the northern part of the State. In 1947 wildfire burned over more than 200,000 acres in Maine, and caused an estimated damage of 12 million dollars (24).

Wildfire not only causes complete loss of timber; it also kills fish and game, temporarily ruins their habitat, destroys recreational assets, impoverishes communities dependent on the forest resource, damages forest soils, and may temporarily destroy the water supply.

The expanding recreational use of the forests and the construction of hundreds of miles of all-weather roads into formerly remote areas is increasing the risk of fire. About 85 percent of the fires in Maine during 1958 were man-caused (24). Therefore every citizen can contribute to the prevention and control of forest fires. He should be careful with all causes of fire in the woods, build campfires only at prescribed places, obtain fire permits as required, and assist in the control of fires wherever his services are required.

New roads are making protection easier. Control efforts are sometimes less costly and more effective because of increased accessibility. And value losses are reduced if immediate salvage logging is possible after serious fire, insect, or disease damage.

Protecting the forests from insects and diseases is often extremely difficult and

Pruning white pine to increase the proportion of clear lumber in the tree. Branches are removed to a beight of about $171 / 2$ feet.

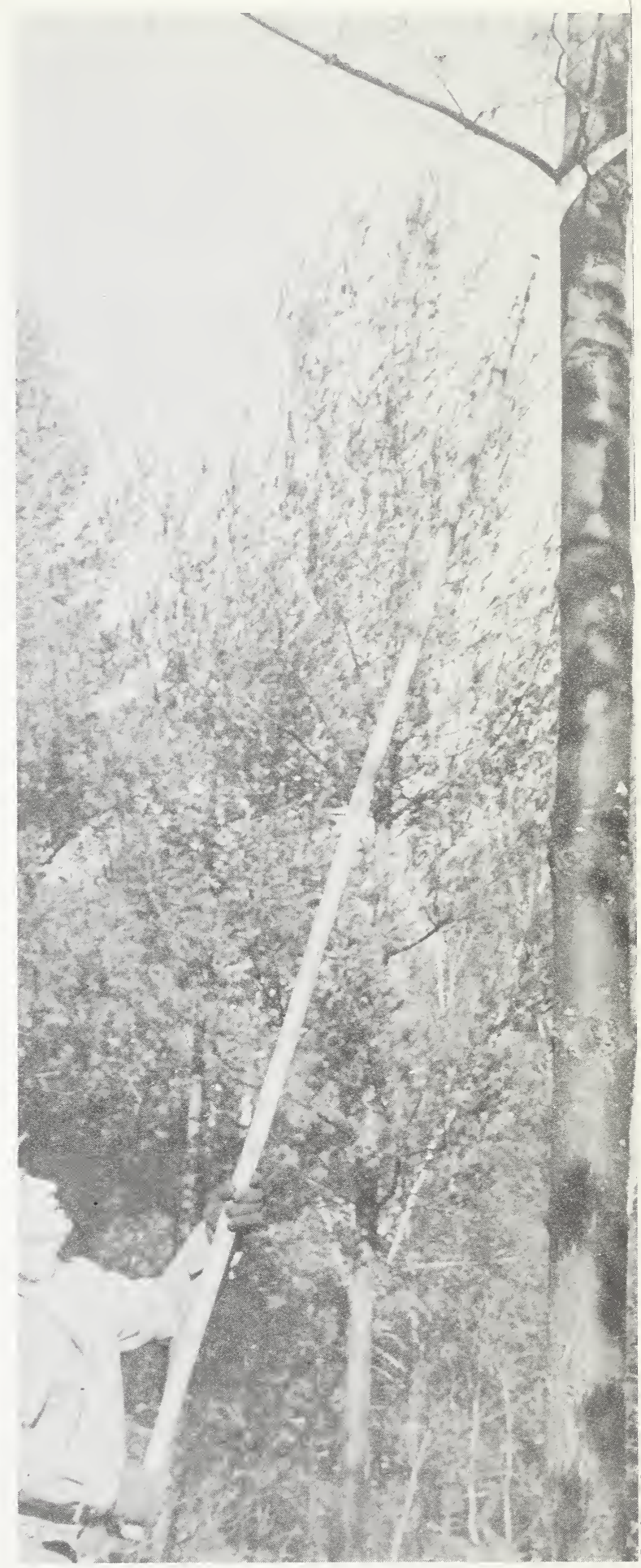


expensive, yet these destructive agents cause large losses in forest growth. Early detection is one important key to effective control. The Maine Forest Service currently has a good detection program. Another way insect and disease losses can be minimized is by maintaining the forests in a healthy, vigorous condition.

The spruce budworm and balsam woolly aphid are capable of causing great losses in forest growth. Both insects are firmly established in the State. The balsam woolly aphid is the least spectacular of the two, but it takes a sizable toll of balsam fir in southern and eastern Maine. The spruce budworm occurred in epidemic proportions in Maine in 1807, 1878, again from 1910 to 1919 (3), and built up to near-epidemic proportions in northern Maine in 1958. The 1910-19 outbreak is estimated to have killed 40 percent of the spruce and balsam fir in the State - some 271/2 million cords!

The white-pine weevil, the most serious of all pests of the eastern white pine, frequently determines the final character of stands seeded on old fields or clearings. Mixed stands of white pine and hardwood are rarely injured badly, but adjacent pure pine stands may be attacked so heavily that their future value for lumber is destroyed. The annual reduction in the value of white pine lumber because of knottiness and crookedness due to attacks by this insect is enormous (19). A recent study in New Hampshire revealed that the white-pine weevil had caused an average growth loss of 13 percent in poletimber-size trees and 40 percent in sawtimber-size trees (23).

White pine blister rust is a destructive disease. It cannot spread directly from pine to pine, but must have pine and Ribes (all varieties of currant and gooseberry) growing in close association. Its control is based on this fact. When the Ribes are removed from the white pine stand and a surrounding protective zone, the disease cannot spread. At the end of 1958 , the acreage of white pine considered for protection in Maine totaled 932,935 acres (24). The control program is financed jointly by the State of Maine, the U. S. Forest Service, the towns and cities of Maine, and in a few cases by individual landowners.

Forest owners and others can help control these losses by reporting sudden in-

Prevention of fire is one way in which everyone can belp to conserve forest values. This Maine Forest Service crew is mopping up the result of someone's carelessness.

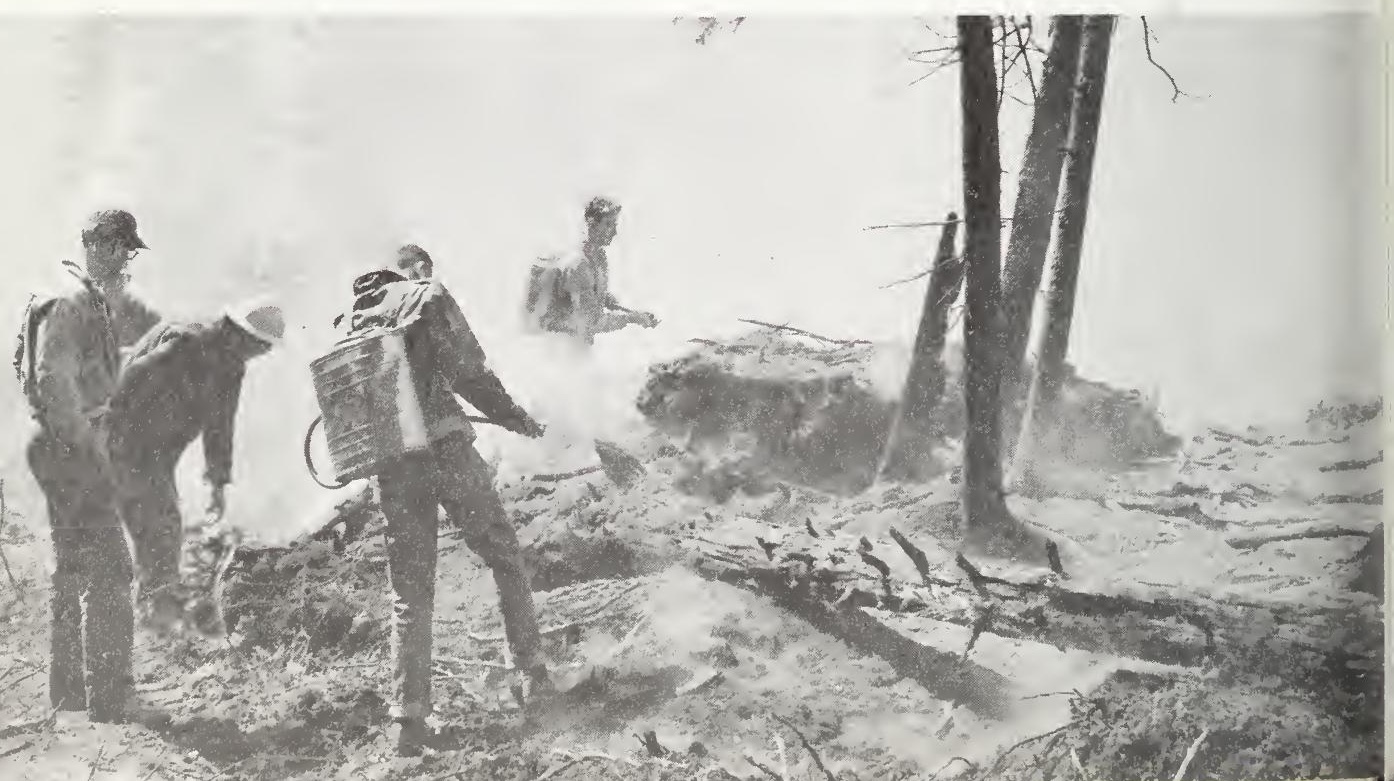


Maine Forest Service photo

The damage that insects do is not sudden and dramatic as a forest fire, yet insects cause tremendous losses in Maine forests. This plane is spraying insecticide in an effort to combat the ravages of the spruce budworm.

sect and disease buildups to the Maine Forest Service, and by supporting research and programs aimed at their control.

\section{ACCELERATED PLANTING}

Maine is estimated to have 100,000 acres of idle land that needs reforestation (22). Some of this land was formerly in farms. Some was barren when the first settlers arrived. And some is the result of fire and other catastrophes. The volume of forest products and income from the forest resource could be materially increased by planting these areas to trees. Pulpwood, sawtimber, or Christmas trees could be grown on these lands, according to the wishes of the owner.

Red and white pine, Norway and white spruce, and small amounts of balsam fir, Douglas-fir, paper birch, and Scotch pine are the principal species planted in Maine. Because each tree species does best under certain conditions of soil, drainage, and other factors, land- owners should consult with a forester before ordering trees for a particular area.

Careful planting and subsequent plantation care are equally important in attaining good survival and growth. Improperly planted trees die; lack of afterplanting care may also result in losses and reduced growth of the surviving trees. Established plantations usually require protection from animals, insects, diseases, and competing vegetation.

\section{ADDITIONAL RESEARCH}

Foresters know a great deal about how to manage forests to increase the production of timber and other forest benefits. However, there are some things they don't know, and many things about which they would like to know more. Additional forestry research would fill these gaps in our professional knowledge of how to manage forest land most wisely.

Additional research in forest management in Maine might be designed to answer some of these questions, for exam- 


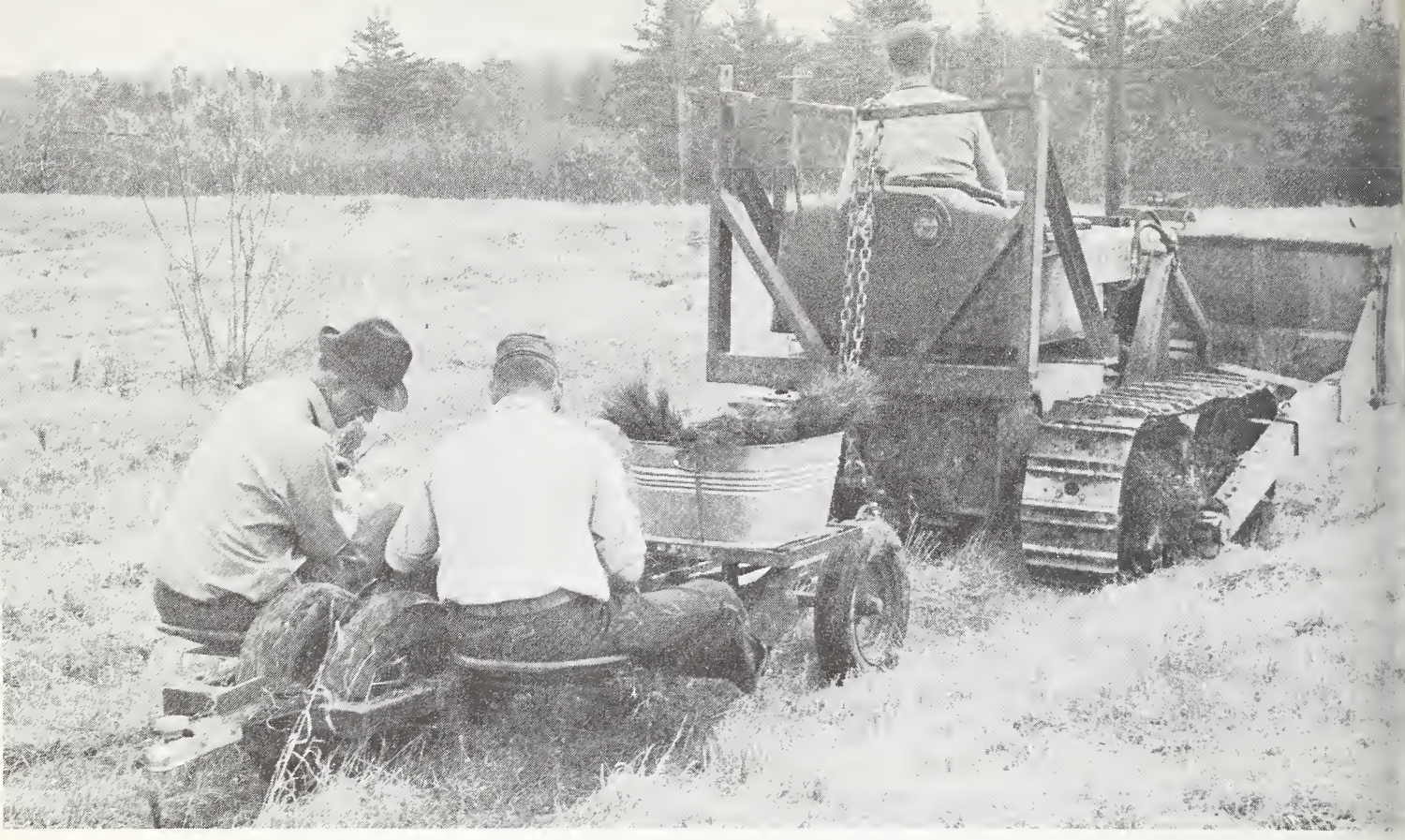

Planting to reforest idle lard. This crew can plant about eight acres a day-about 10,000 trees. Maine has some 100,000 acres of idle land that need reforestation.

pie: How dense should spruce-fir forests be in order to grow the greatest quantity and the highest quality of timber? At what size should dominant hardwood and softwood trees be harvested? How do we regenerate some of our more desirable hardwoods and conifers? What is the best way to release young white pine seedlings that are being suppressed by brush on the burned-over areas in southern Maine? What are the financial returns from pruning young pine, spruce, and hardwoods?

Additional research in forest insects and diseases might be designed to find better ways of controlling the white-pine weevil, such as by aerial spraying; more efficient techniques for controlling the spruce budworm; more deadly predators to attack the balsam woolly aphid and other insects; and more effective ways of controlling blister rust, heart rots, and other diseases.
Research in forest utilization might be designed to develop new chemical processes that would make possible the utilization of some of the lower-grade trees in Maine's forests; to produce and test new logging and harvesting techniques for handling small trees more efficiently; and to develop new products to be manufactured from those tree species that are abundant in Maine.

Forest fire research might be expanded to enable foresters to predict when weather conditions are such that fires of catastrophic proportions are likely to occur, so that special precautions can be taken. Had such knowledge been available years ago, some of Maine's disastrous fires might have been prevented.

Research in forest recreation, wildlife, watershed protection, soils, tree physiology, and other related fields might also help foresters to increase the benefits that Maine's people will derive from their forests. 


\section{Current Programs To Improve Management}

CINCE less than 1 percent of Maine's $\checkmark$ commercial forest area is in public ownership, most of the improvement in forestry practices must take place on private lands. Some measures are already used by many landowners. Interest in better forest management is increasing among all classes of owners, particularly among industrial concerns that depend upon forests for their raw material.

A number of public and privately sponsored programs such as professional forestry services, cost-sharing programs, and protection programs are aimed at improving the forest resource. These programs are available to all owners, from the largest industrial concern to the individual owner who has a few acres of woodland.

\section{PROFESSIONAL FORESTRY SERVICES}

Long-term returns from forests are closely related to the skill and intensity of the management these forests receive. Most of the large landowners in Maine employ professional foresters to plan the overall management of their forests and to supervise harvest cuttings and related treatments. As a result, most of the large industrial forests are being managed under long-term management plans. Management of these forests is becoming more intensive year by year.

But most of the people who own forest land in Maine hold tracts so small that they do not require the full-time services of a professional forester. These owners can get limited advice from the State Extension Forester, they can employ a consulting forester on a part-time basis, they can obtain the services of an industry forester, or they can get assistance from the Maine Forest Service.

When a landowner asks for this latter service, a State-employed forester goes over the woodland with him. The forester then prescribes a forest-management plan that fits the particular woodland and the owner's personal needs. The management plan may include harvest cuttings; tree planting; protection from fire, insects, diseases, and grazing; and stand-improvement practices.

Working with the owners, these Stateemployed foresters assist in marking trees to be cut. They help the owner find timber operators who are skilled in cutting on a marked-tree basis. They provide marketing information, and they can help the owner arrange for sale of timber according to the management plan recommended for the woodland.

This service is free. The 18 State-employed service foresters in Maine gave assistance to nearly 5,000 landowners in 1958 (24). More than 35 million boardfeet of timber was harvested under their supervision during the year, bringing the owners a gross return of $\$ 720,000$.

Requests for assistance from a service forester can be made to the Maine Forest Service, the County Agricultural Extension Service, and the Soil Conservation Service.

The Maine unit of the nationwide Tree-Farm Program, sponsored by the American Forest Products Industries in cooperation with the Maine Forest Service, actively promotes improved forest practices. Owners who manage their 
woodlands according to established standards receive certificates and roadside signs stating that the woodlands have met Tree-Farm standards. In Maine, woodlots of 5 acres or more that are managed for commercial wood products on a sustained-yield basis are eligible for membership in this program. Subsequent forest operations and practices on these areas must meet Tree-Farm standards, or the certification is withdrawn.

By the end of 1959, more than onequarter million acres of woodland had been certified in 396 active Tree Farms in the State. Any landowner, large or small, may apply for membership. Requests for additional information can be directed to

Maine Forest Service photo

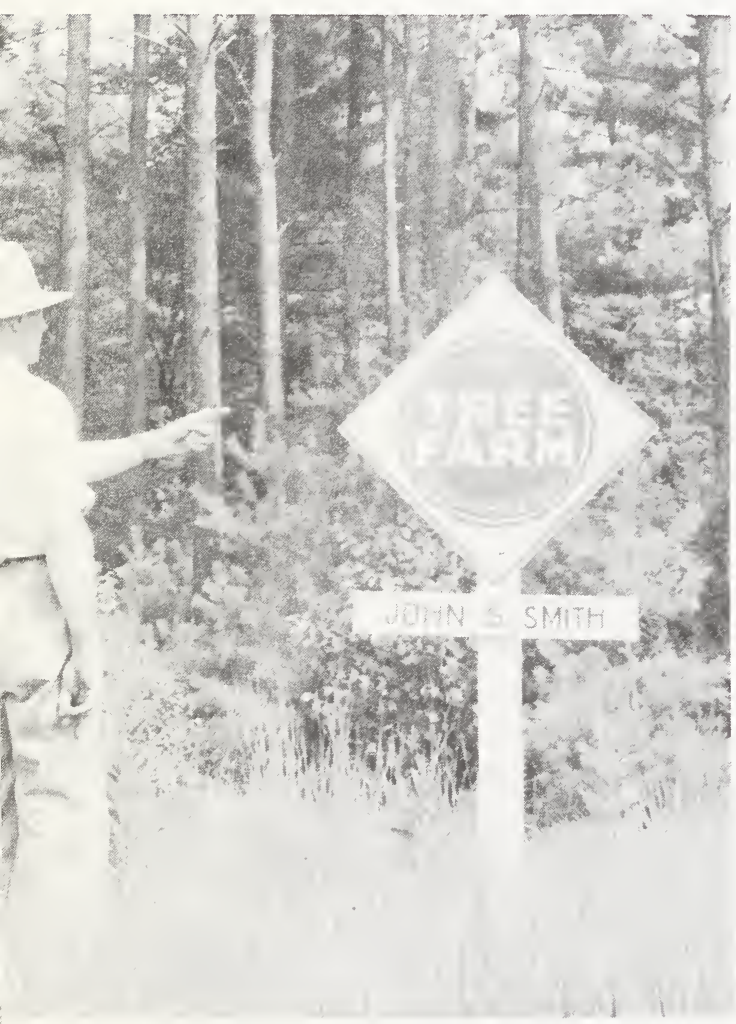

The Tree Farm program is one of the current activities to promote better forest practices. There are now about 400 Tree Farms in Maine. the Maine Forest Service or any large wood-using company in the State.

Recognizing the benefits of improved cutting practices, some wood-using industries have sponsored the Tree Farm Fam. ily program in the Portland, Rumford, and Waterville areas. At present the $\mathrm{Ox}$ ford Paper Company, S. D. Warren Paper Company, Scott Paper Company, and the Diamond National Corporation employ full-time company foresters to assist woodland owners who are members of their respective Tree Farm Families. These foresters provide services similar to those of State-employed service foresters. People owning woodlots within the purchasing area of a sponsoring company can apply to the company for assistance in woodland management.

Similar assistance from industrial foresters is available in other areas, even though formalized Tree Farm Families have not been established.

\section{COST-SHARING PROGRAMS}

Farm woodland owners who plan tim. ber-stand-improvement measures for their woodlands may qualify for cost-sharing payments under the Agricultural Conservation Program (18). Federal costshare payments are available for improvement cuttings in older stands from which non-merchantable or inferior trees are marked and removed. Payments are also available for weeding to improve young stands. This weeding program includes the removal of undesirable and nonmerchantable trees in young stands, leav. ing 200 to 800 well-distributed future crop trees per acre. Also payments are available for pruning white or red pine. At least 100 well-distributed red or white pine future crop trees must be pruned on each acre, after proper weeding and thinning, to qualify for the cost-sharing payment. 
Federal cost-sharing payments for any combination of forest-improvement practices on farmland are now limited to a maximum of $\$ 25$ per acre. Stand improvement must be conducted under the direction and advice of a forester. No Federal cost-sharing payments is allowed for any area from which merchantable products are harvested in the process of carrying out the practice, unless the primary purpose of the operation is to improve the residual stand of trees.

The Agricultural Conservation Program changes somewhat from year to year. Individuals may obtain up-to-date information on this program through the Maine Forest Service, the County Agricultural Extension Service, the Soil Conservation Service, or local Agricultural Conservation Program offices.

Several Government programs offer assistance to landowners who are interested in planting trees for timber production. Trees are available at or below cost from the Maine Forest Service nursery at Greenbush. In 1959, three-year-old red pine, white pine, Norway spruce, and white spruce seedlings cost $\$ 11$ per thousand, delivered. Nursery production is aimed at 8 to 10 million seedlings annually. Planting stock may also be obtained from a privately owned nursery at Fryeburg, or from out-of-state sources.

Under the Soil Bank Program, landowners may enter contractual agreements with the Federal Government for planting cropland and hayland to trees for a period of 10 years. The Government reimburses the landowner for the initial planting cost at specified rates according to the number of trees planted per acre. The owner is also paid an annual rental for each acre planted under contract. The rental rate for each planting is determined by the productivity rating of the planted area. At the end of 1959, 17,000 acres of former cropland were enrolled in this program.

Service foresters from the Maine Forest Service examine all land entered under the tree-planting phase of the Soil Bank Program, and recommend the number and kind of trees to be planted. They also arrange for the planting stock and, in most cases, arrange for planting machines and crews. As a rule, they also train and supervise the planting crews.

Cost sharing is also available to owners planting forest trees on farmland under the Agricultural Conservation Program (18). The maximum Federal cost-share is based on the number of trees planted per acre, and whether or not brush and scrub trees had to be cleared from the planted areas. No Federal cost-sharing is allowed for clearing by aerial spraying or for clearing a stand of merchantable timber or pulpwood.

\section{PROTECTION PROGRAMS}

The Maine Forest Service is responsible for fire protection on forest lands within the State. This service cost approximately $51 / 2$ cents an acre on the 17 million acres protected during the 1957 . 58 biennium, one of the lowest per-acre costs in the country.

The State is divided into two organizational set-ups for fire-protection purposes: (1) the Maine Forestry District; and (2) the organized towns. The Maine Forestry District contains 10,356,042 acres held by 657 owners in the unorganized towns of the State. The forest area protected in the organized towns encompasses $6,616,958$ acres owned by 76,822 individuals or industrial concerns. The State protection force consists of 264 people, with another 2,100 on call.

Landowners can obtain assistance or advice on fire protection problems from 
the Division of Forest Fire Control of the Maine Forest Service. State Fire Wardens issue campfire and burning permits for the Maine Forestry District.

A total of 99 lookout stations are strategically located throughout the State, 73 of them in the Maine Forestry District. Volunteer fire companies throughout the State are also available for fire-conirol work.

The Maine Forestry District fire-control budget for the 1957-58 biennium amounted to $\$ 1,434,465$, approximately three-fourths coming from a tax on the private landowners and one-fourth from the Federal Government (24). The budget for the organized towns amounted to $\$ 824,487$ for the same period, about one-fourth coming from the Federal Government and the balance from State appropriations and miscellaneous taxes and licenses.

Protecting the State's woodlands from insects is also a responsibility of the Maine Forest Service, with assistance from the U. S. Forest Service and other agencies. The program comprises detection and assessment surveys, research, and control of insect outbreaks. Six forestinsect rangers conduct periodic surveys of forest areas for insect damage.

Measures are taken when necessary to control outbreaks threatening the forests. In 1958 about 300,000 acres of forest in northern Aroostook County were sprayed from the air to control a dangerous buildup of the spruce budworm, which threatened to destroy the spruce and balsam fir in that area. Though the spraying program destroyed 96 percent of the budworm population in the sprayed area, the outbreak has continued in other areas, and another 175,000 acres are scheduled for spraying in 1960. State, private, and Federal funds are used for this work. Aerial spraying is also used to control cankerworms, gypsy moth, and other insects as needed.

Predacious insects (which prey upon other insects) have been reared and liberated to control destructive forest insects. And recently a test was conducted with insects that were imported from Germany.

The State program for controlling forest diseases is limited mainly to protecting eastern white pine from the blister rust. This disease can be controlled by eliminating gooseberry and currant bushes in and near stands that contain white pine. Some $\$ 177,000$ of cooperative funds was spent for blister rust control in Maine in 1957 and 1958 (24).

Questions and requests for assistance in controlling forest pests may be directed to the Maine Forest Service. This service is free.

\section{RESEARCH AND EDUCATION}

A considerable amount of forestry research is already being conducted in Maine. Leaders in such research are the Northeastern Forest Experiment Station of the U. S. Forest Service, with field headquarters and experimental forests at Bangor and Alfred; the School of Forestry and Agricultural Experiment Station of the University of Maine, in Orono; and the Maine Forest Service, with headquarters at Augusta. Major research efforts by these agencies in Maine are concentrated in forest management, forest entomology, and wildlife management.

The Maine Forest Service and the organized towns work to prevent and combat forest fires. Protection forces are beadquartered at small stations throughout the forest areas; and men and equipment are dispatched to fires by road, air, and water. 

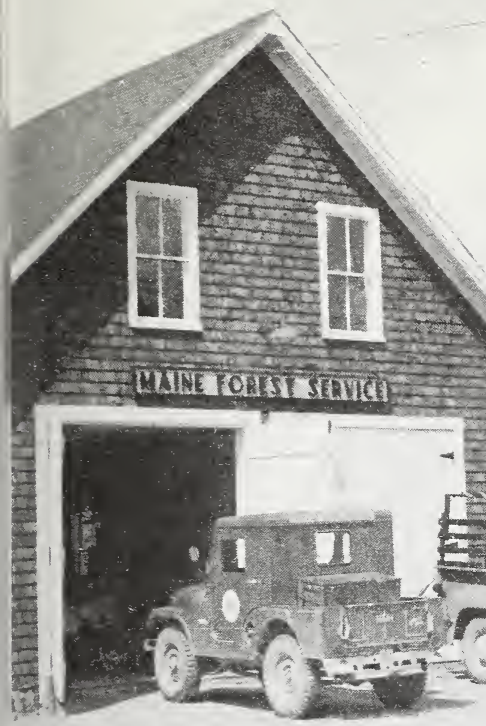

$\sqrt[11 \div \pi]{10}$

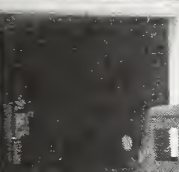

r

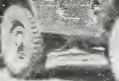

\section{tos $-2 \cdot 1$}

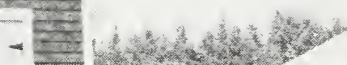

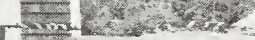

5

,

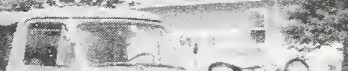

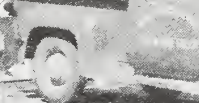

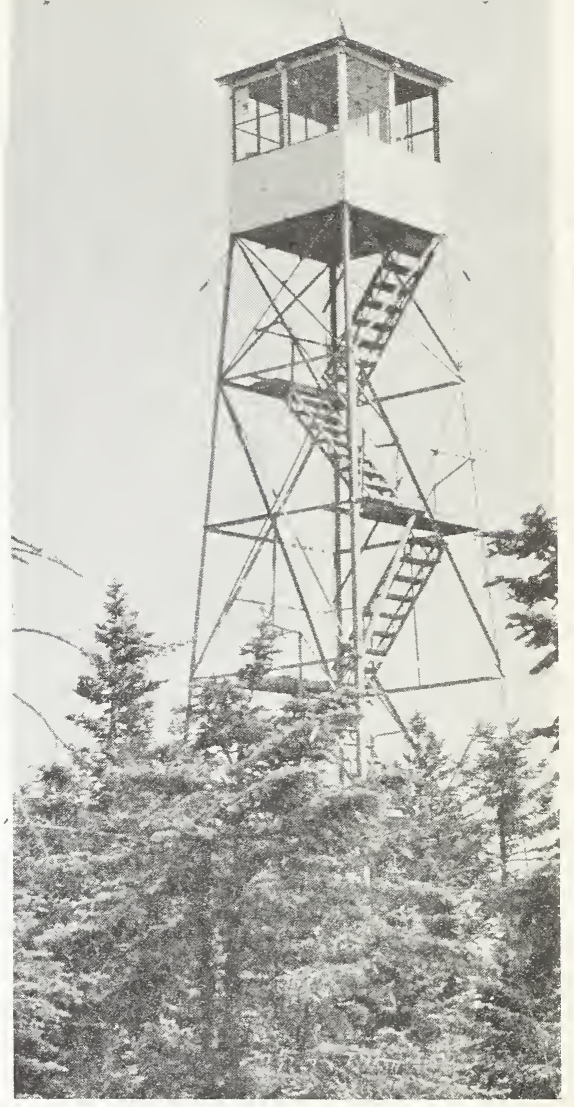

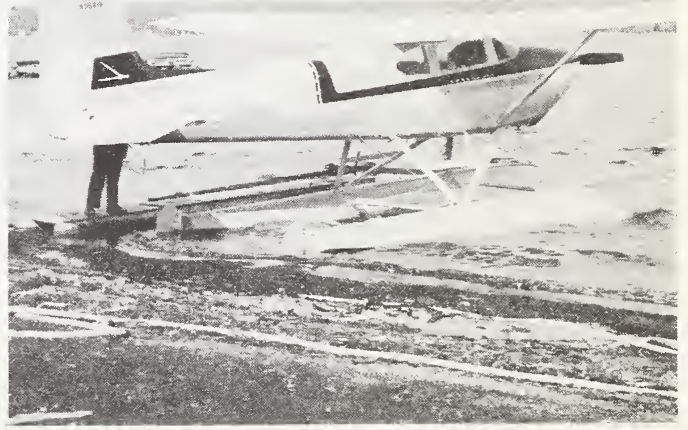



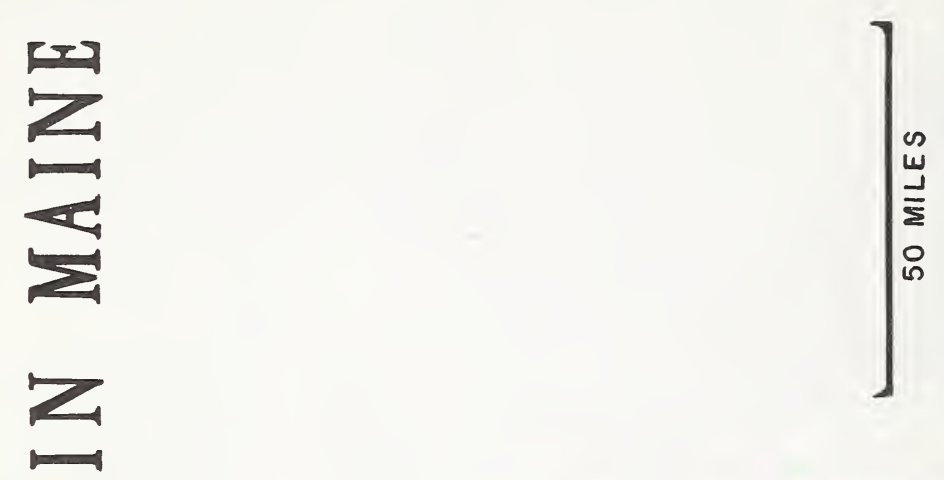

날
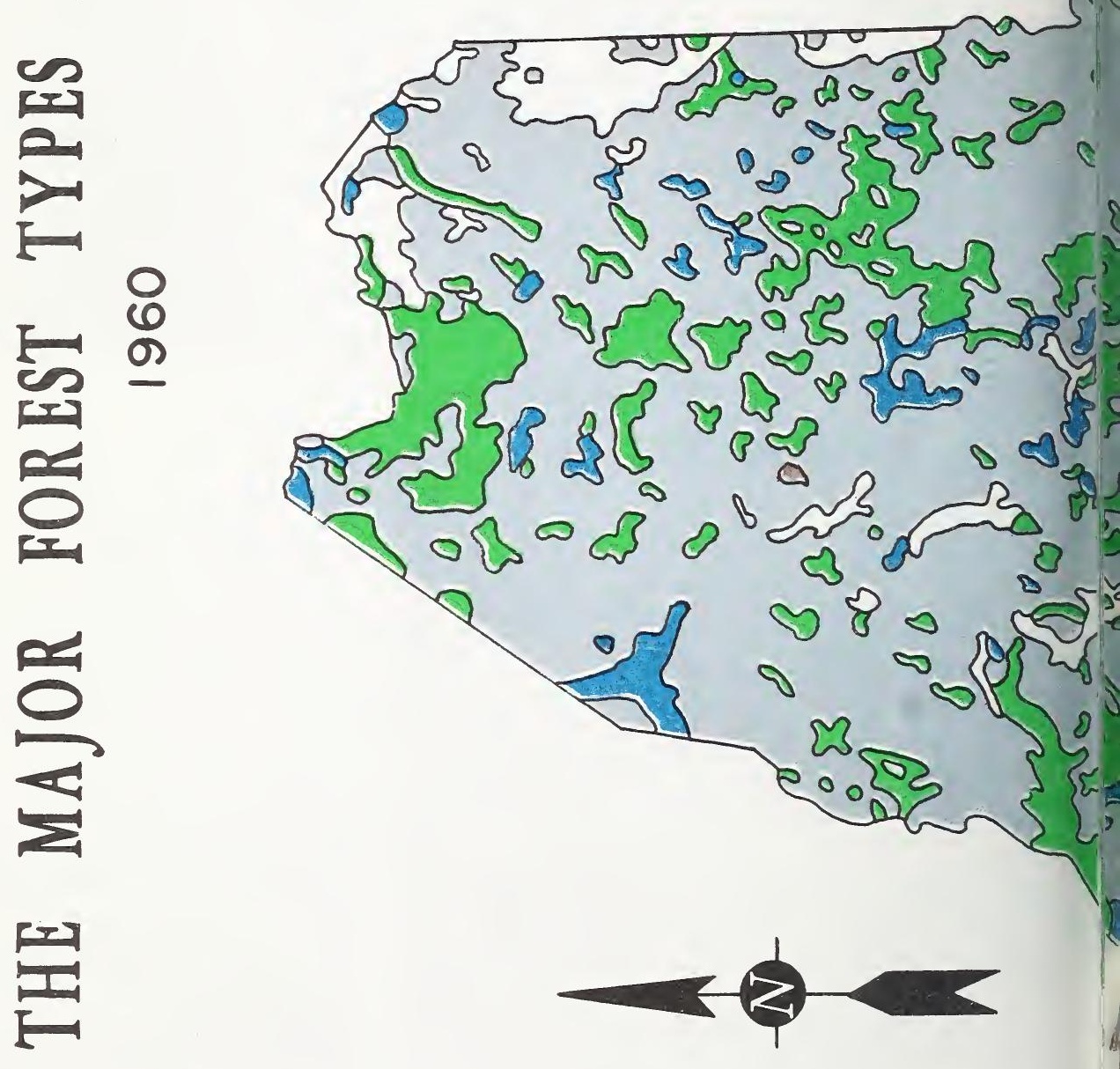

피 
A number of the larger forest-owning companies are also engaged in forestry research. Part of their research is done independently, and part is done in cooperation with these three public agencies. Timber-growth studies, a timberquality study, and the forest survey upon which this report is based, are recent examples of cooperative research between industry and public agencies.

In Maine, education in forestry is the primary responsibility of the University of Maine and the Maine Extension Service, although all of the forestry programs that have been mentioned have educa- tional aspects. The University of Maine School of Forestry, one of the oldest in the Northeast, trains students who upon graduation become professional foresters eligible for membership in the Society of American Foresters.

Forestry education through the Extension Service is closely connected with the University's forestry program. Extension foresters are headquartered at Orono. Their function is to convey the results of forestry research to foresters and landowners through demonstrations and various other media.

\section{A Favorable Outlook}

M AINE is a forest state. Forests cover 87 percent of its land area. More than 17 million acres of commercial forest land are within its boundaries. This amounts to 18 acres of forest for every person in the State - more than six times the national average.

These forests are Maine's greatest natural resource. They provide raw material for a large lumber industry. They support a large and expanding pulp and paper industry. And in addition they provide a steady water supply, plentiful fish and game, and an ever increasing amount of outdoor recreation.

Maine's forests at present support a timber inventory of more than 200,000,000 cords. However, not all of this is immediately usable. Some of it is too small, some is too remote, some is in species not presently desired by industry, and some is too scattered to be harvested economically. But all of it is growing and will enable greater timber harvests to be made in the future.
This timber inventory is large enough to supply the present needs of Maine's wood-using industries. And since Maine's forests are now growing more than twice as much wood as is being cut, the inventory is increasing and the prospects for supporting an expansion of these industries appear to be excellent. Such an expansion would mean additional employment, a higher value of products produced in the State, and other benefits to Maine's people.

However, such achievements will not be possible without adjustments in utilization and management practices. The forestry picture has its dark clouds. One is that, in some of the more desired species and sizes of trees, the inventory is declining. The cut of pine sawlogs in 1958 exceeded growth by 41 percent. The cut of hard-hardwood sawlogs exceeds growth by almost 25 percent. In many cutting operations only the better quality trees are cut, leaving behind the less desirable sizes, grades, and species. 
Another problem is the huge annual loss through mortality to insects, diseases, fire, and other causes. The volume of trees that die from these causes is greater than the volume that is currently being used by the wood-using industries.

But these problems can also be viewed as opportunities, for each of these diffculties has a solution. And if forestry research, utilization, and management are expanded, Maine's people can expect an even greater harvest of values from Maine's forests in the future.

\section{LITERATURE CITED}

(1) Baker, Gregory C.

1947. THE PRIMARY WOOD USING INDUSTRIES OF MAINe. Univ. Maine Agr. Expt. Sta. Bul. 448, 260 pp., illus.

(2) Chapman, Leonard Bond.

1896. The Mast Industry OF Old FalMoUTH. Maine Hist. Soc. Collect. \& Proc. 2nd Ser. 7: 390-404.

(3) Canada Department of Agriculture.

1924. STUdies ON THE SPRUCE BUDworm. Canada Dept. Agr. Bul. 37 (n.s.), 91 pp., illus.

(4) Defebaugh, James Elliott.

1907. HISTORY OF THE LUMBER INDUSTRY OF AMERICA. Ed. 1, vol. 2, 655 pp., illus. Chicago.

(5) Horn, Stanley Fitzgerald.

1943. This FAsCINATING LUMBer BUSINESs. Ed. 1, 338 pp., illus. New York.

(6) Lockwood Trade Journal.

1940. 250 YEARS OF PAPER MAKING IN AMERICA. 180 pp., illus. New York.

(7) Maine Department of Economic Development.

(n.d.) Maine Buyer's Guide and direcTORY OF MAINE MANUFACTURERS, 1959-60. 95 pp., illus.

(8) Maine Department of Inland Fisheries and Game.

1958. STATE of MAINE INLAND FisherIES AND GAME FINANCIAL REPORT, JULy 1, 1957 - JUNE 30, 1958. 15 pp. (mimeo.).

(9) Maine Department of Labor and Industry 1959. Census of Maine manufacturERS-1958. Maine Dept. Labor and Indus. Bul. 270, 21 pp., illus.
(10) Maine Forest Service.

1959. AUTHORIZED PUBLIC CAMP SITES AND LUNCH GROUNDS DESIGNATED FOR FIRE PROTECTION. Maine Forest Serv. 42 pp., illus.

(11) Maine State Highway Commission.

(n.d.) MAINe ROADSide PICNic aREas. Maine Highway Comm. Illus.

(12) Maine State Park Commission and $\mathrm{Na}$ tional Park Service.

1956. A RECREATION PLAN FOR MAINE, 1956. 56 pp., illus.

(13)

1952. STATE OF MAINE PRELIMINARY REPORT ON STATE PARK AND RELATEd Planning. Maine State Park Comm. 39 pp., illus.

(14) Nutting, Albert D.

1957. THIRTY-FIRST BIENNIAL REPORT OF the Forest COMmissioner, 1955 1956. Maine Forest Serv. 160 pp., illus.

(15) Stackpole, Everett Schermerhorn.

1903. Old KITTERY AND HER FAMILIES. 822 pp., illus. Lewiston, Maine.

(16) Steer, Henry B.

1948. LUMBER PRODUCTION IN THE United States, 1799-1946. U. S. Dept. Agr. Misc. Pub. 669, 233 pp., illus.

(17) United States Congress.

1870. FOREIGN COMMERCE AND DECADENCE OF AMERICAN SHIPPING. Report of chief of the division of tonnage ... in relation to the foreign commerce of the United States ... 41st. Cong. 2nd Sess. Exec. Doc. 111. 
(18) United States Department of Agriculture. 1959. Agricultural Conservation PROGRAM HANDBOOK FOR 1960, Maine. U. S. Dept. Agr., Agr. Conserv. Program Pub. ACP.1960. Me. 30 pp.

(19) United States Department of Agriculture. 1949. INSECT ENEMIES OF EASTERN FORESTS. U. S. Dept. Agr. Misc. Pub. 657, 679 pp., illus.

(20) United States Fish and Wildlife Service. 1956. NATIONAI SURVEY OF FISHING AND HUNTING. U. S. Fish and Wildlife Serv. Circ. 44, 50 pp., illus.

(21) United States Forest Service.

1959. WOOD PULP MILls IN THE UNITED STATES BY STATE AND TYPE OF PRODUCT. U. S. Forest Serv., 20 pp., illus.

(22)

1958. TIMBER RESOURCES FOR AMERICA'S
FUTURE. U. S. Forest Serv. Forest Resource Rpt. 14, 713 pp., illus.

(23) Waters, W. E., McIntyre, T., and Crosby, D.

1955. LOSS IN VOLUME OF WHITE PINE IN NEW HAMPSHIRE CAUSED BY THE WHITE-PINE WEEVIL. Jour. Forestry 53: 271-274.

(24) Wilkins, Austin H.

1959. THIRTY-SECOND BIENNIAL REPORT OF THE FOREST COMMISSIONER, MAINE FOREST SERV., 100 pp., illus.

(25)

1932. THE FORESTS OF MAINE. Maine Forest Serv. Bul. 8, 107 pp., illus.

(26) Wood, Richard G:

1935. A HISTORY OF LUMBERING IN MAINE, 1820-1861. Univ. Maine Studies; 2nd Ser. No. 33. 267 pp., illus. 


\section{APPENDIX}

FOREST SURVEY DATA

Tables of forest statistics were compiled from the findings of the Forest Survey of Maine, which began in Hancock County in 1946. Many of the field plots established at that time were remeasured in 1958 , and the original volumes ${ }^{6}$ were then brought up to date. The inventory date for the State is January 1, 1959. Timber growth and cut statistics are for 1958. These data are grouped as follows:

Timber growth and cut-tables 1 to 6 and 31 .

Timber inventory volume-tables 7 to 15 and 26 to 29 .

Area, condition, and ownership of forest land-tables 16 to 25,30 , and 31 .

Wherever cubic-foot volume is shown, the cordwood equivalent can be obtained by multiplying by 0.0125 . This converting factor is based upon an average of 80 cubic feet of wood to 1 cord of unpeeled bolts.

\section{INDEX TO TABLES}

To facilitate compilation of Forest Survey data for any group of states, region, or the Nation as a whole, a set of 10 standard tables is presented in U. S. Forest Service Forest Survey statistical reports. In this report these tables are designated by an asterisk.

*Output of timber products and annual cut of live sawtimber and growing stock. .

Net volume of growing stock and sawtimber cut, by species.............

*Net annual growth, annual mortality, and annual cut of live sawtimber and growing stock on commercial forest land, by species group .................

Net annual growth and timber cut of live sawtimber and stock on commercial forest land, by species group..........

Components of net annual growth of growing stock on commercial forest land, by species group............

Components of net annual growth of sawtimber on commercial forest land, by species group ................

*Net volume of live sawtimber and grow. ing stock on commercial forest land, by species .....................

Quality of white pine and hardwood sawtimber on commercial forest land, by species $\ldots \ldots \ldots \ldots \ldots \ldots \ldots$. . . .

${ }^{6}$ Forest statistics for Hancock County, Maine. U. S. Forest Serv. Northeast. Forest Exp. Sta., Forest Survey Release 4. 30 pp., 1949.
*Area of commercial forest land by major fea commercial forest land, by major forest types .................

Commercial forest-land area, by forest-type group and stand-size class..........

Commercial forest-land area, by drainage areas and stand-size class......... 19 
*Commercial forest land area, by ownership and stand-size classes.........

Number of private owners and total acreage of privately owned commercial forest land, by size-of-holding class......

Land area and commercial forest land area, by county...............

Commercial forest land area, by ownership

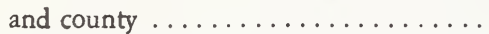

Commercial forest land area, by foresttype group and county...........

Commercial forest land area, by stand-size class and county..............
Net volume in live sawtimber, by species and county ............... 26

Net volume suitable for pulpwood by species and county............... 27

Net volume of live sawtimber, by standsize class, species group, and county... 28

Net volume of growing stock, by standsize class, species group, and county... 29

Commercial forest area and volume, by pulpwood volume - per - acre - class and county ................. 30

Pulpwood and sawlogs harvested, by species group and county group....... 31

\section{DEFINITION OF TERMS}

\section{FOREST AREA}

Forest land area. - This includes: (a) lands that are at least 10 percent stocked with trees of any size and are capable of producing timber or other wood products, or of exerting an influence on the climate or on the water regime; (b) land from which the trees described in (a) have been removed to less than 10 percent stocking and that has not been developed for other use; and (c) afforested areas. (Forest tracts of less than 1 acre, isolated strips of timber less than 120 feet wide, and abandoned fields and pastures not yet 10 percent stocked with trees are excluded.)

Commercial forest land area. - Forest land that is (a) producing, or physically capable of producing, usable crops of wood (usually sawtimber); (b) economically available now or prospectively; and (c) not withdrawn from timber utilization through statute, ordinance, or administrative order.

Noncommercial forest land area.-Forest land (a) withdrawn from timber utilization through statute, ordinance, or administrative order, but that otherwise qualifies as commercial forest land; or (b) incapable of yielding usable wood products (usually sawtimber) because of adverse site conditions, or so physically inaccessible as to be unavailable economically in the foreseeable future.

\section{FOREst COVER TyPes}

The forest cover types are classified according to the predominant species or species group, as indicated by cubic volume for sawtimber and poletimber stands, and number of trees for seedling-andsapling stands. All local forest types in Maine are keyed to the following five major types:

White pine-red pine. - Forests in which 50 percent or more of the stand is eastern white pine or red pine, singly or in combination. In Maine it includes the white pine and hemlock types. A negligible acreage of the pitch pine type is also included.

Spruce-fir. - Forests in which 50 percent or more of the stand is spruce and fir. In Maine it includes the spruce-fir, spruce-fir-hardwood, and cedar-tamarackspruce types.

Oak-hickory. - Forests in which 50 percent or more of the stand is made up of various species of oak.

Elm-ash-cottonwood (swamp hardwoods). - Forests in which 50 percent or more of the stand is in red maple, elm, ash, or associated species, singly or in

(Continued on page 69.) 


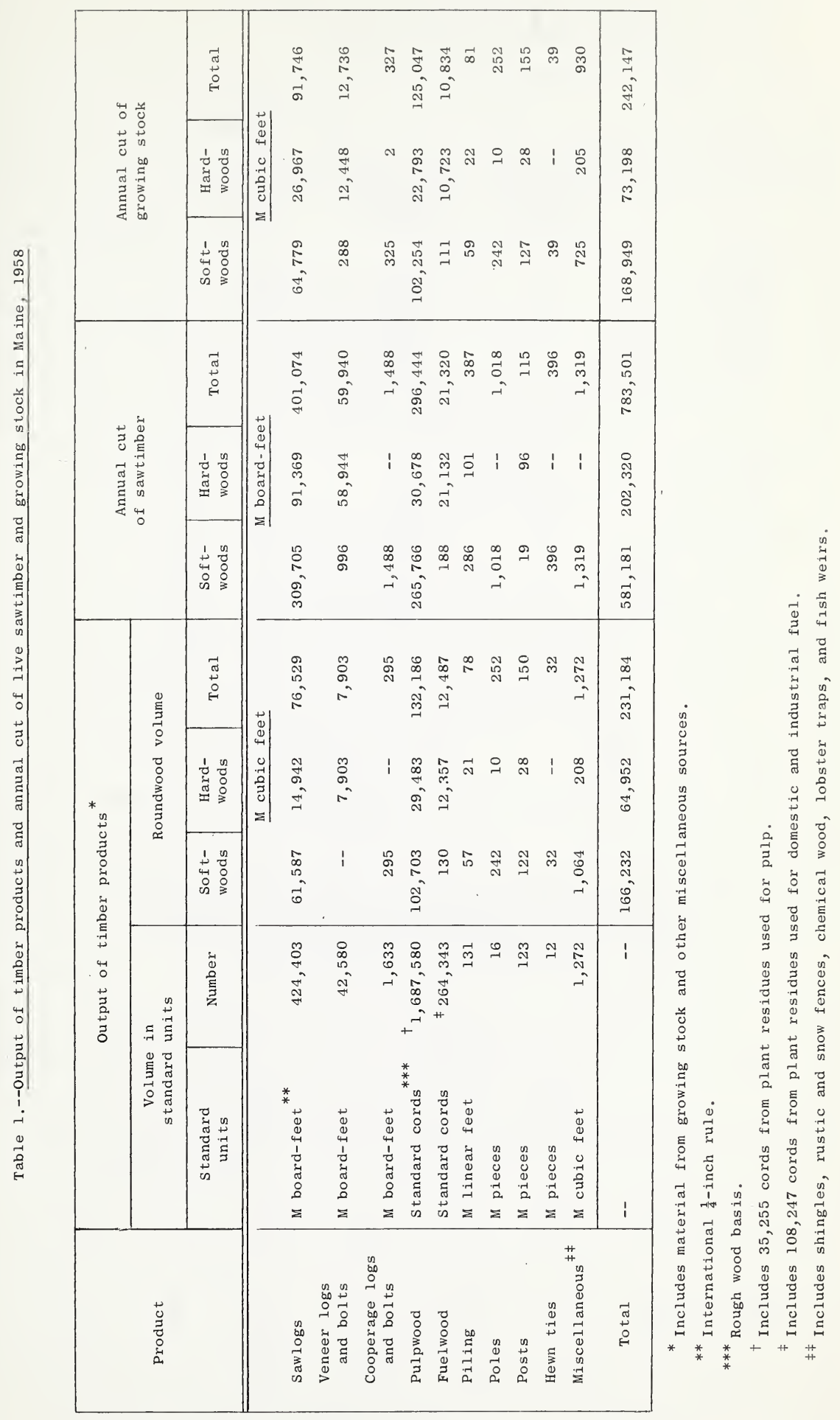


Table 2.--Net volume of growing stock and sawtimber cut from Maine forests, by species, 1958

\begin{tabular}{|c|c|c|c|}
\hline Species & Growing & stock cut & $\begin{array}{c}\text { Live } \\
\text { sawtimber } \\
\text { cut }\end{array}$ \\
\hline & $\frac{\text { Million }}{\text { cu.ft. }}$ & $\frac{\frac{\text { Equivalent }}{\text { in thousand }}}{\text { cords }}$ & $\frac{\text { Million }}{\text { bd-ft. }}$ \\
\hline $\begin{array}{l}\text { Softwoods: } \\
\text { Spruce } \\
\text { Balsam fir } \\
\text { White pine } \\
\text { Hemlock } \\
\text { Cedar } \\
\text { Other softwoods }\end{array}$ & $\begin{array}{r}66 \\
40 \\
38 \\
20 \\
4 \\
1\end{array}$ & $\begin{array}{r}825 \\
500 \\
475 \\
250 \\
50 \\
12\end{array}$ & $\begin{array}{r}232 \\
106 \\
153 \\
72 \\
13 \\
5\end{array}$ \\
\hline Al1 softwoods & 169 & 2,112 & 581 \\
\hline $\begin{array}{l}\text { Hardwoods: } \\
\text { Sugar maple } \\
\text { Beech } \\
\text { Yellow birch } \\
\text { Paper birch } \\
\text { Red oak } \\
\text { Other hardwoods }\end{array}$ & $\begin{array}{r}23 \\
16 \\
12 \\
11 \\
5 \\
6\end{array}$ & $\begin{array}{r}288 \\
200 \\
150 \\
137 \\
63 \\
75\end{array}$ & $\begin{array}{l}63 \\
35 \\
34 \\
40 \\
19 \\
11\end{array}$ \\
\hline All hardwoods & 73 & 913 & 202 \\
\hline All species & 242 & 3,025 & 783 \\
\hline
\end{tabular}

Table 3.--Net annual growth, annual mortality, and annual cut of live sawtimber and growing stock on commercial forest 1 and in Maine, by species group, 1958

\begin{tabular}{|c|c|c|c|c|c|c|}
\hline \multirow{2}{*}{ I tem } & \multicolumn{3}{|c|}{ Sawtimber } & \multicolumn{3}{|c|}{ Growing stock } \\
\hline & $\begin{array}{l}\text { Soft- } \\
\text { woods }\end{array}$ & $\begin{array}{l}\text { Hard- } \\
\text { woods }\end{array}$ & Total & $\begin{array}{l}\text { Soft- } \\
\text { woods }\end{array}$ & $\begin{array}{l}\text { Hard- } \\
\text { woods }\end{array}$ & Total \\
\hline & \multicolumn{3}{|c|}{ Million board-feet } & \multicolumn{3}{|c|}{ Million cubic feet } \\
\hline Net annual growth & 711 & 252 & 963 & 404 & 170 & 574 \\
\hline Annual mortality & 351 & 152 & 503 & 189 & 83 & 272 \\
\hline $\begin{array}{l}\text { Annual cut } \\
\text { Timber products } \\
\text { Logging residues }\end{array}$ & $\begin{array}{r}565 \\
16\end{array}$ & $\begin{array}{r}164 \\
38\end{array}$ & $\begin{array}{r}729 \\
54\end{array}$ & $\begin{array}{r}156 \\
13\end{array}$ & $\begin{array}{l}56 \\
17\end{array}$ & $\begin{array}{r}212 \\
30\end{array}$ \\
\hline Total & 581 & 202 & 783 & 169 & 73 & 242 \\
\hline
\end{tabular}


Table 4.--Net annual growth and timber cut of 1 ive

sawtimber and growing stock on commercial forest 1 and, by species group, Maine, 1958

\begin{tabular}{|c|c|c|}
\hline Species group & $\begin{array}{c}\text { Net annual } \\
\text { growth }\end{array}$ & $\begin{array}{c}\text { Timber } \\
\text { cut }\end{array}$ \\
\hline \multicolumn{3}{|c|}{$\begin{array}{c}\text { LIVE SAWTIMBER } \\
\text { Million board-feet } \\
\end{array}$} \\
\hline $\begin{array}{l}\text { White and red pine } \\
\text { Spruce and fir } \\
\text { other softwoods } \\
\text { Soft hardwoods } \\
\text { Hard hardwoods }\end{array}$ & $\begin{array}{r}107.7 \\
513.2 \\
89.7 \\
124.8 \\
127.2\end{array}$ & $\begin{array}{r}152.6 \\
338.4 \\
90.2 \\
45.6 \\
156.7\end{array}$ \\
\hline A11 species & 962.6 & 783.5 \\
\hline \multicolumn{3}{|c|}{$\begin{array}{c}\text { GROWING STOCK } \\
\text { Million cubic feet } \\
\end{array}$} \\
\hline $\begin{array}{l}\text { White and red pine } \\
\text { Spruce and fir } \\
\text { other softwoods } \\
\text { Soft hardwoods } \\
\text { Hard hardwoods }\end{array}$ & $\begin{array}{r}31.5 \\
319.0 \\
53.4 \\
112.6 \\
57.6\end{array}$ & $\begin{array}{r}37.9 \\
105.8 \\
25.2 \\
15.5 \\
57.7\end{array}$ \\
\hline Al1 species & $\begin{array}{l}574.1^{*} \\
\text { cords }\end{array}$ & $242.1^{* *}$ \\
\hline $\begin{array}{l}\text { White and red pine } \\
\text { Spruce and fir } \\
\text { Other softwoods } \\
\text { Soft hardwoods } \\
\text { Hard hardwoods }\end{array}$ & $\begin{array}{r}394 \\
3,987 \\
668 \\
1,407 \\
720\end{array}$ & $\begin{array}{r}474 \\
1,322 \\
315 \\
194 \\
721\end{array}$ \\
\hline A11 species & 7,176 & 3,026 \\
\hline
\end{tabular}

*Net annual growth sampling error is \pm 9.1 percent. ** Timber cut sampling error is \pm 9.2 percent. 
Table 5.--Components of net annual growth of growing stock on commercial forest land, by species group, Maine, 1958

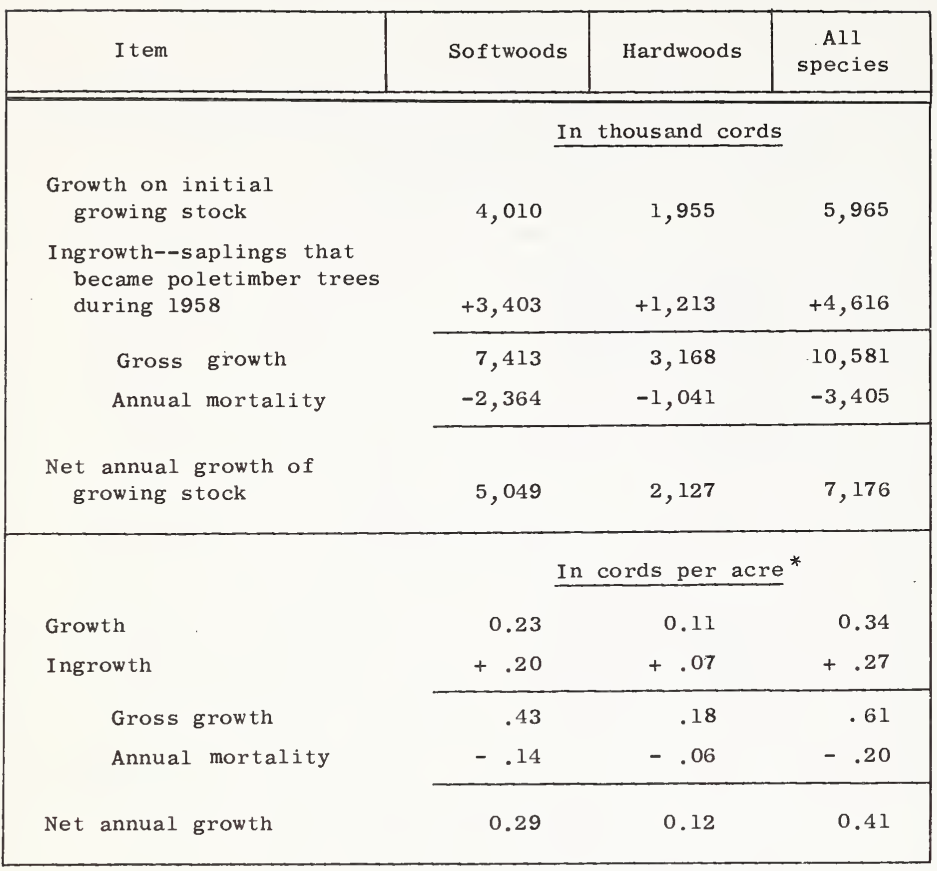

* The difference in rates between "growing stock" and "volume suitable for pulpwood" is negligible (a difference of 0.01 cord net growth for total of all species).

Table 6.--Components of net annual growth of sawtimber on commercial forest land, by species group, Maine, 1958

(In millions of board-feet)

\begin{tabular}{|c|c|c|c|}
\hline I tem & Sof twoods & Hardwoods & $\begin{array}{c}\text { All } \\
\text { species }\end{array}$ \\
\hline $\begin{array}{l}\text { Growth on initial } \\
\text { sawtimber inventory }\end{array}$ & 476 & 174 & 650 \\
\hline $\begin{array}{c}\text { Ingrowth-poletimber } t \\
\text { that became sawtimb } \\
\text { trees during } 1958\end{array}$ & +586 & +230 & +816 \\
\hline Gross growth & 1,062 & 404 & 1,466 \\
\hline Annual mortality & -351 & -152 & -503 \\
\hline Net annual growth & 711 & 252 & 963 \\
\hline
\end{tabular}


Table 7.--Net volume of live sawtimber and growing stock on commercial forest land, by species, Maine, 1959

\begin{tabular}{|c|c|c|c|}
\hline Species & Sawtimber & \multicolumn{2}{|c|}{ Growing stock } \\
\hline & $\frac{\text { Million }}{\mathrm{bd}-\mathrm{ft} .}$ & $\frac{\text { Million }}{\text { cu.ft. }}$ & $\begin{array}{l}\text { Equivalent in } \\
\text { million cords }\end{array}$ \\
\hline $\begin{array}{l}\text { Softwoods: } \\
\text { Spruce } \\
\text { White pine } \\
\text { Balsam fir } \\
\text { Cedar } \\
\text { Hemlock } \\
\text { Other softwoods }\end{array}$ & $\begin{array}{r}7,482 \\
5,000 \\
3,340 \\
2,063 \\
1,833 \\
232\end{array}$ & $\begin{array}{r}3,633 \\
1,468 \\
3,249 \\
1,350 \\
892 \\
154\end{array}$ & $\begin{array}{r}45.4 \\
18.4 \\
40.6 \\
16.9 \\
11.1 \\
1.9\end{array}$ \\
\hline A11 softwoods & 19,950 & 10,746 & 134.3 \\
\hline $\begin{array}{l}\text { Hardwoods: } \\
\text { Sugar maple } \\
\text { Yellow birch } \\
\text { Red maple } \\
\text { Beech } \\
\text { Paper birch } \\
\text { Aspen } \\
\text { Ash } \\
\text { Northern red oak } \\
\text { Other hardwoods }\end{array}$ & $\begin{array}{r}3,019 \\
2,615 \\
1,248 \\
1,013 \\
938 \\
529 \\
395 \\
390 \\
346\end{array}$ & $\begin{array}{r}945 \\
940 \\
1,137 \\
644 \\
817 \\
605 \\
279 \\
203 \\
198\end{array}$ & $\begin{array}{r}11.8 \\
11.8 \\
14.2 \\
8.0 \\
10.2 \\
7.6 \\
3.5 \\
2.5 \\
2.5\end{array}$ \\
\hline Al1 hardwoods & 10,493 & 5,768 & 72.1 \\
\hline All species & 30,443 & 16,514 & 206.4 \\
\hline
\end{tabular}

Table 8.--Quality of white pine and hardwood sawtimber on commercial forest land, Maine, 1959

(In millions of board-feet)

\begin{tabular}{|c|c|c|c|c|c|}
\hline \multirow{2}{*}{ Species } & \multicolumn{3}{|c|}{ Standard lumber logs } & \multirow{2}{*}{$\begin{array}{r}\text { Tie and } \\
\text { timber } \\
\text { logs } *\end{array}$} & \multirow{2}{*}{ Total } \\
\hline & $\begin{array}{c}\text { Grade } \\
1\end{array}$ & $\begin{array}{c}\text { Grade } \\
2\end{array}$ & $\begin{array}{c}\text { Grade } \\
3\end{array}$ & & \\
\hline White pine ${ }^{* *}$ & 605 & 2,415 & 1,980 & $(* * *)$ & 5,000 \\
\hline Sugar maple & 580 & 996 & 969 & 474 & 3,019 \\
\hline Yellow birch & 745 & 722 & 868 & 280 & 2,615 \\
\hline Red maple & 99 & 377 & 656 & 116 & 1,248 \\
\hline Paper birch & 142 & 252 & 371 & 173 & 938 \\
\hline Aspen & 23 & 140 & 260 & 106 & 529 \\
\hline Ash & 90 & 158 & 122 & 25 & 395 \\
\hline Northern red oak & 55 & 78 & 193 & 64 & 390 \\
\hline Other hardwoods & 46 & 323 & 706 & 284 & 1,359 \\
\hline All hardwoods & 1,780 & 3,046 & 4,145 & 1,522 & 10,493 \\
\hline
\end{tabular}

* Meet minimum specifications for tie and timber logs but not for standard lumber logs (See Appendix for specifications).

** other softwoods not graded.

*** Not applicable to white pine. 
Table 9.--Net volume of live sawtimber and growing stock on commercial forest land and area occupied, by stand-size class, Maine, 1959

\begin{tabular}{|c|c|c|c|c|}
\hline Stand-size class & Area & $\begin{array}{c}\text { Sawtimber } \\
\text { volume }\end{array}$ & \multicolumn{2}{|c|}{ Growing stock } \\
\hline & $\frac{\text { Thous and }}{\text { acres }}$ & $\frac{\text { Million }}{\text { bd.-ft. }}$ & $\frac{\text { Million }}{\text { cu.ft. }}$ & $\frac{\text { Equivalent in }}{\text { miliion cords }}$ \\
\hline $\begin{array}{l}\text { Sawtimber stands: } \\
\text { More than } 5,000 \\
\text { board-feet per acre } \\
1,500 \text { to } 5,000 \\
\text { board-feet per acre }\end{array}$ & $\begin{array}{l}1,416 \\
5,361\end{array}$ & $\begin{array}{r}9,482 \\
15,469\end{array}$ & $\begin{array}{l}2,981 \\
7,192\end{array}$ & $\begin{array}{l}37.2 \\
89.9\end{array}$ \\
\hline Al1 sawtimber stands & 6,777 & 24,951 & 10,173 & 127.1 \\
\hline Poletimber stands & 7,933 & 5,222 & 6,057 & 75.7 \\
\hline $\begin{array}{l}\text { Seedling-and-sapling } \\
\text { stands }\end{array}$ & 1,900 & 171 & 239 & 3.0 \\
\hline $\begin{array}{l}\text { Nonstocked and other } \\
\text { areas not elsewhere } \\
\text { classified }\end{array}$ & 559 & 99 & 45 & .6 \\
\hline Al1 stands & * 17,169 & $* * 30,443$ & $* * * 16,514$ & 206.4 \\
\hline
\end{tabular}

* Standard error $=0.4$ percent.

** Standard error $=2.4$ percent.

*** standard error $=1.4$ percent. 
Table 10.--Net volume of live sawtimber and growing stock on commercial forest land, by ownership class, Maine, 1959

\begin{tabular}{|c|c|c|c|}
\hline Ownership class & Sawtimber & \multicolumn{2}{|c|}{ Growing stock } \\
\hline & $\frac{\text { Million }}{\text { bd.-ft. }}$ & $\frac{\text { Million }}{\text { cu.ft. }}$ & $\frac{\text { Equivalent in }}{\text { million cords }}$ \\
\hline $\begin{array}{l}\text { Federal: } \\
\text { National forest } \\
\text { Other Federal }\end{array}$ & $\begin{array}{r}122 \\
46\end{array}$ & $\begin{array}{l}59 \\
24\end{array}$ & $\begin{array}{r}0.7 \\
.3\end{array}$ \\
\hline Total Federal & 168 & 83 & 1.0 \\
\hline State & 109 & 62 & .8 \\
\hline Municipal & 127 & 73 & .9 \\
\hline $\begin{array}{l}\text { Private: } \\
\text { Farm } \\
\text { Forest industry } \\
\text { Other private }\end{array}$ & $\begin{array}{r}3,492 \\
12,789 \\
13,758\end{array}$ & $\begin{array}{l}1,881 \\
6,837 \\
7,578\end{array}$ & $\begin{array}{l}23.5 \\
85.5 \\
94.7\end{array}$ \\
\hline Total private & 30,039 & 16,296 & 203.7 \\
\hline Al1 ownerships & 30,443 & 16,514 & 206.4 \\
\hline
\end{tabular}

* Volumes for National forest ownership are for the 45,862 acres in the White Mountain National Forest and 3,694 acres in the Massabesic Experimental Forest.

Table 11.--Net volume of live sawtimber on commercial forest 1 and, by diameter-class group and species, Maine, 1959

(In millions of board-feet)

\begin{tabular}{|c|c|c|c|c|c|c|c|}
\hline \multirow{2}{*}{ Species } & \multicolumn{6}{|c|}{ Diameter-class group (in inches) } & \multirow{2}{*}{ Total } \\
\hline & 10 & 12 & 14 & 16 & 18 & $20+$ & \\
\hline White and red pine & 581 & 875 & 754 & 710 & 467 & 1,613 & 5,000 \\
\hline Other eastern softwoods & 5,296 & 3,958 & 2,448 & 1,621 & 659 & 968 & 14,950 \\
\hline Total softwoods & 5,877 & 4,833 & 3,202 & 2,331 & 1,126 & 2,581 & 19,950 \\
\hline Northern red oak & -- & 99 & 99 & 64 & 46 & 82 & 390 \\
\hline Yellow birch & -- & 429 & 459 & 470 & 369 & 888 & 2,615 \\
\hline Sugar maple & -- & 406 & 463 & 583 & 583 & 984 & 3,019 \\
\hline Beech & -- & 409 & 330 & 177 & 79 & 18 & 1,013 \\
\hline Other eastern hardwoods & -- & 1,290 & 933 & 653 & 297 & 283 & 3,456 \\
\hline Total hardwoods & -- & 2,633 & 2,284 & 1,947 & 1,374 & 2,255 & 10,493 \\
\hline All species & 5,877 & 7,466 & 5,486 & 4,278 & 2,500 & 4,836 & 30,443 \\
\hline
\end{tabular}




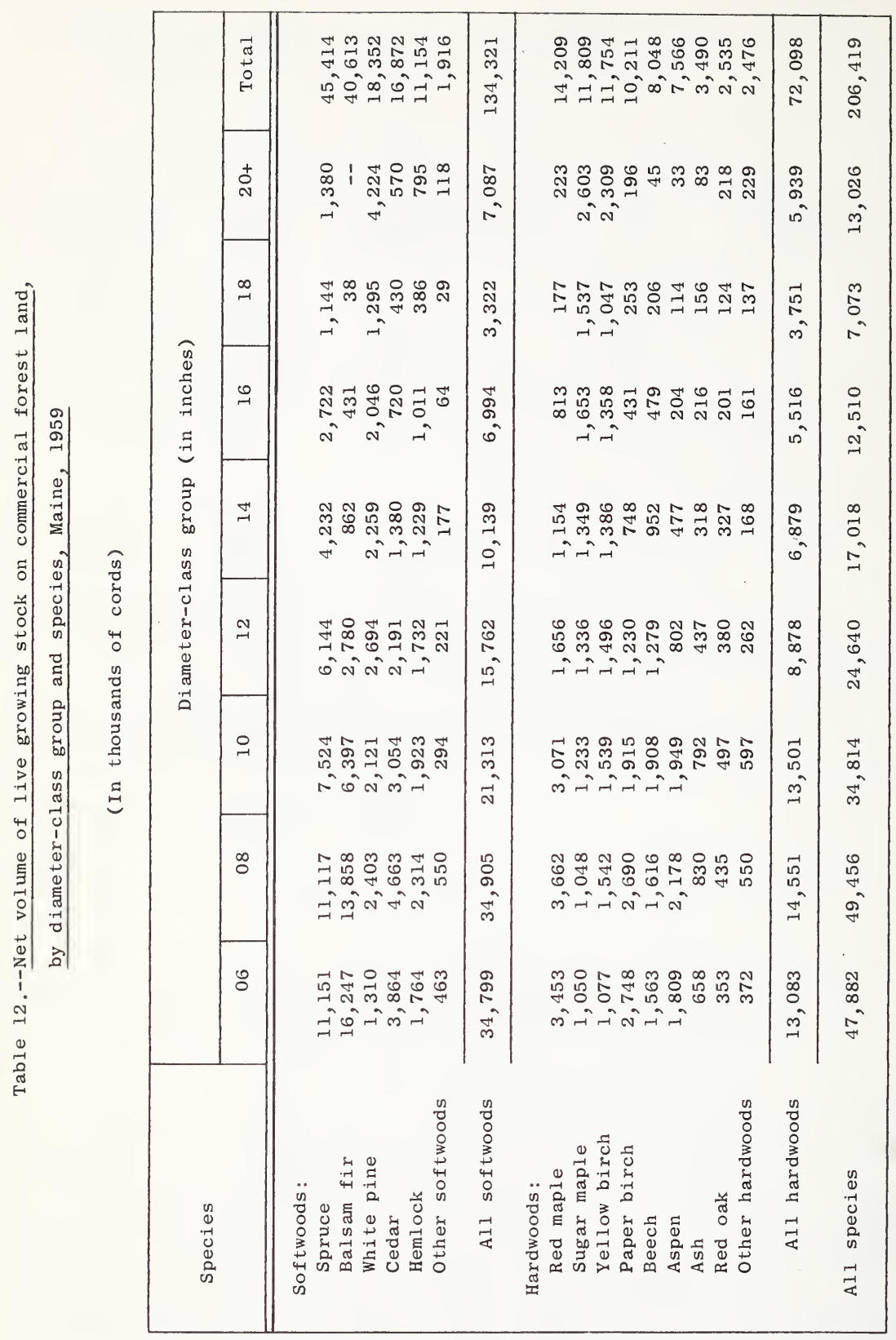




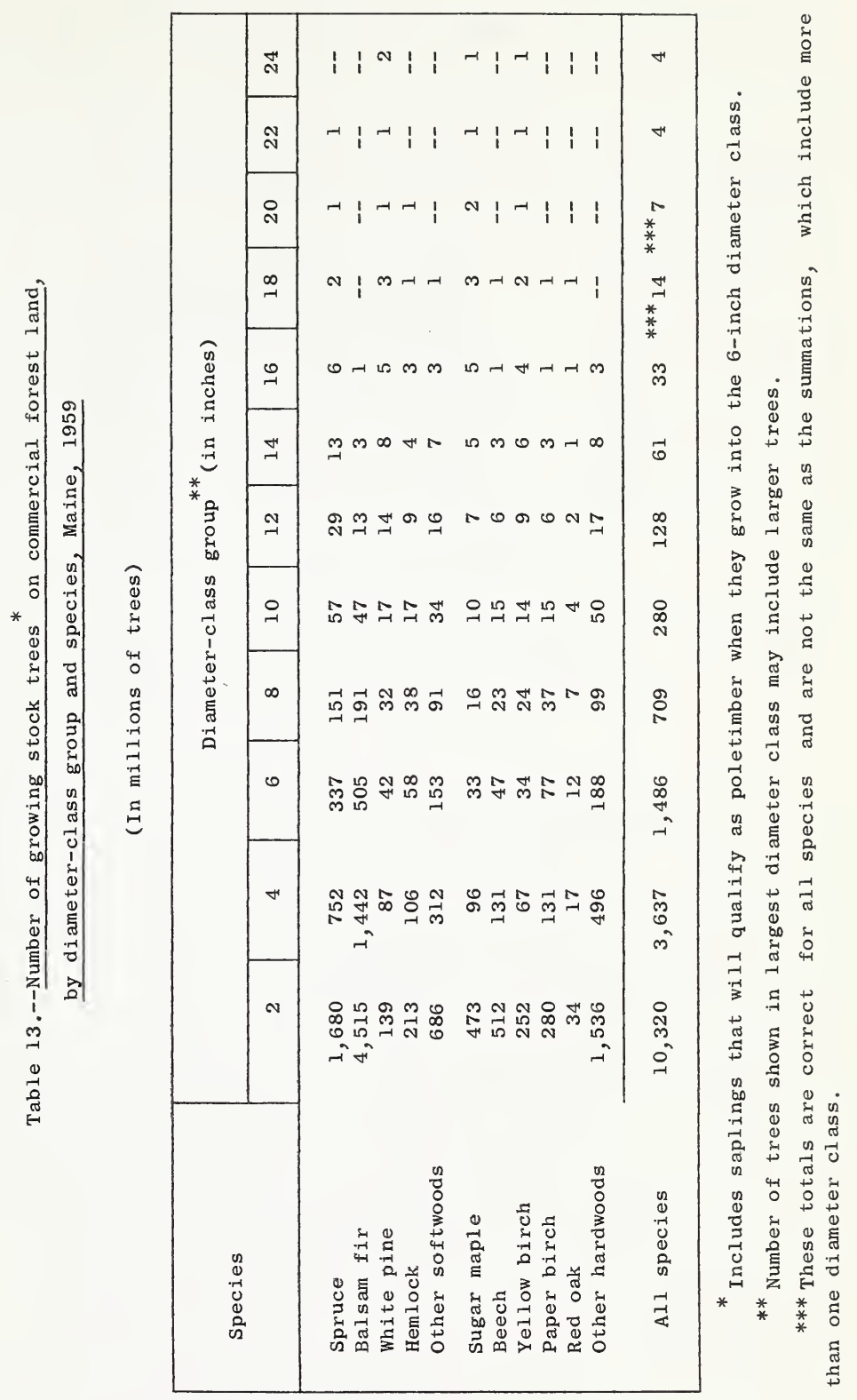


Table 14.--Net volume of all timber on commercial forest land, by class of material and species group, Maine, 1959

(In millions of cubic feet)

\begin{tabular}{|c|c|c|c|}
\hline Class of material & $\begin{array}{c}\text { All } \\
\text { species }\end{array}$ & Softwoods & Hardwoods \\
\hline \multicolumn{4}{|l|}{ Growing stock: } \\
\hline $\begin{array}{l}\text { Sawtimber trees } \\
\text { Sawlog portion } \\
\text { Upper-stem portion }\end{array}$ & $\begin{array}{r}6,721 \\
881\end{array}$ & $\begin{array}{r}4,573 \\
556\end{array}$ & $\begin{array}{r}2,148 \\
325\end{array}$ \\
\hline Total & 7,602 & 5,129 & 2,473 \\
\hline Poletimber trees & 8,912 & 5,617 & 3,295 \\
\hline Total growing stock & 16,514 & 10,746 & 5,768 \\
\hline \multicolumn{4}{|l|}{ Other material ${ }^{*}$} \\
\hline Sound cull trees & 1,591 & 1,028 & 563 \\
\hline Rotten cull trees & 1,249 & 424 & 825 \\
\hline Hardwood limbs & 1,018 & -- & 1,018 \\
\hline Total other material & 3,858 & 1,452 & 2,406 \\
\hline Total, all timber & 20,372 & 12,198 & 8,174 \\
\hline
\end{tabular}

* The item "salvable dead trees" is not included here because there is only negligible volume of this class of material in Maine.

Table 15.--Net volume suitable for pulpwood *

on commercial forest 1 and, by species,

Maine, 1959

\begin{tabular}{|c|c|}
\hline Species & $\begin{array}{l}\text { Volume suitable } \\
\text { for pulpwood }\end{array}$ \\
\hline & $\frac{\text { Million }}{\text { cords }}$ \\
\hline \multicolumn{2}{|l|}{ Sof twoods: } \\
\hline Spruce & 44.5 \\
\hline Balsam fir & 41.0 \\
\hline White pine & 18.5 \\
\hline Cedar & 18.3 \\
\hline Hemlock & 10.7 \\
\hline Other softwoods & 1.9 \\
\hline A11 softwoods & 134.9 \\
\hline \multicolumn{2}{|l|}{ Hardwoods: } \\
\hline Red maple & 14.2 \\
\hline Yellow birch & 11.1 \\
\hline Sugar maple & 11.0 \\
\hline Paper birch & 10.0 \\
\hline Beech & 8.1 \\
\hline Aspen & 7.4 \\
\hline Ash & 3.4 \\
\hline Red oak & 2.4 \\
\hline other hardwoods & 3.0 \\
\hline Al1 hardwoods & 70.6 \\
\hline A.11 species & 205.5 \\
\hline
\end{tabular}

* The volumes shown in this table are slightly different from those shown for growing stock (table 7) because they exclude certain portions of growingstock trees and include some volume of cull trees. 


\begin{tabular}{|c|c|c|}
\hline Class of land & \multicolumn{2}{|c|}{ Area } \\
\hline & $\frac{\text { Thousand }}{\text { acres }}$ & Percent \\
\hline \multicolumn{3}{|l|}{ Forest: } \\
\hline Commercial & 17,169 & 86 \\
\hline $\begin{array}{l}\text { Noncommercial: } \\
\text { Productive but reserved } \\
\text { Unproductive }\end{array}$ & $\begin{array}{r}158 \\
98\end{array}$ & $\begin{array}{r}1 \\
(*)\end{array}$ \\
\hline Al1 forest 1 and & 17,425 & 87 \\
\hline Nonforest $* *$ & 2,441 & 13 \\
\hline All 1 and & 19,866 & 100 \\
\hline
\end{tabular}

* Less than $\frac{1}{2}$ percent.

** Includes 188,000 acres of water according to Forest Survey standards of area classification but defined by the Bureau of Census as 1 and. 
Table 17.--Area of commercial forest 1 and, by major forest types, Maine, 1959

\begin{tabular}{|c|c|}
\hline Forest type & Area \\
\hline & $\frac{\text { Thousand }}{\text { acres }}$ \\
\hline $\begin{array}{l}\text { White-red-jack pine: } \\
\text { White pine* } \\
\text { Hemlock }\end{array}$ & $\begin{array}{r}1,224 \\
415\end{array}$ \\
\hline & 1,639 \\
\hline $\begin{array}{l}\text { Spruce-fir: } \\
\text { Spruce-fir } \\
\text { Spruce-fir-hardwood } \\
\text { Cedar-tamarack-spruce }\end{array}$ & $\begin{array}{l}4,764 \\
2,297 \\
1,322\end{array}$ \\
\hline Cedar-tamarack-spruce & $\begin{array}{r}8,383 \\
287\end{array}$ \\
\hline $\begin{array}{l}\text { Swamp hardwoods: } \\
\text { Ash-elm-maple } \\
\text { Red maple }\end{array}$ & $\begin{array}{l}303 \\
202\end{array}$ \\
\hline Red maple & 505 \\
\hline $\begin{array}{l}\text { Maple-beech-birch: } \\
\text { Sugar maple-beech-yel low birch } \\
\text { Hardwood-spruce-fir } \\
\text { Hardwood-white pine }\end{array}$ & $\begin{array}{r}2,836 \\
2,076 \\
200\end{array}$ \\
\hline Hardwood-white pine & 5,112 \\
\hline $\begin{array}{l}\text { Aspen-birch: } \\
\text { Aspen } \\
\text { Gray birch-pin cherry } \\
\text { Paper birch }\end{array}$ & $\begin{array}{l}485 \\
422 \\
336\end{array}$ \\
\hline & 1,243 \\
\hline All types & 17,169 \\
\hline
\end{tabular}

* Includes 15,000 acres of the pitch pine and jack pine types.

** This type would be combined with the oakhickory type for regional totals. 


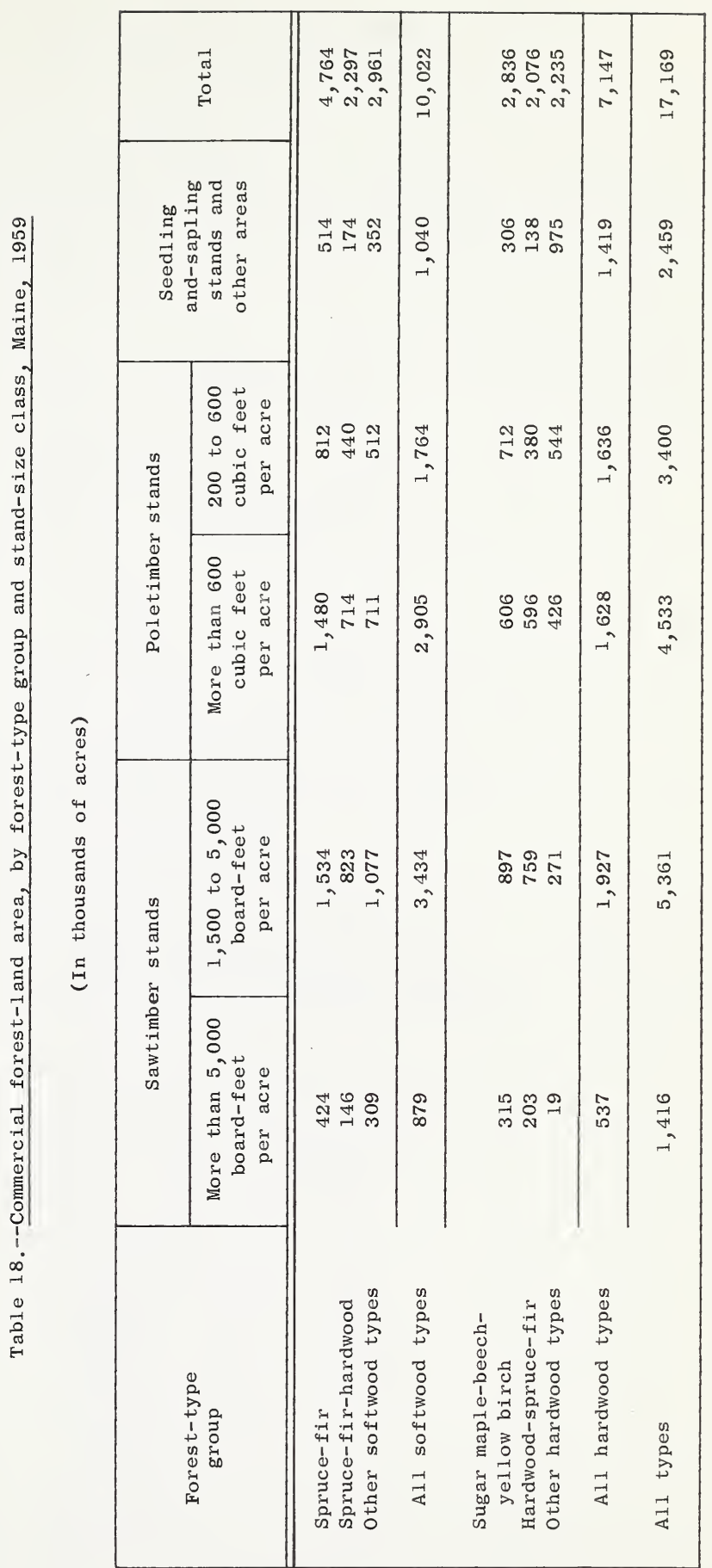


Table 19.--Commercial forest land area, by drainage areas and stand-size class, Maine, 1959

(In thousands of acres)

\begin{tabular}{|c|c|c|c|c|}
\hline $\begin{array}{c}\text { Drainage } \\
\text { area }\end{array}$ & $\begin{array}{c}\text { All } \\
\text { stands }\end{array}$ & $\begin{array}{c}\text { Sawtimber } \\
\text { stands }\end{array}$ & $\begin{array}{c}\text { Poletimber } \\
\text { stands }\end{array}$ & $\begin{array}{c}\text { Other stands } \\
\text { and areas }\end{array}$ \\
\hline Androscoggin River & $i, 788$ & 517 & 865 & 406 \\
\hline Aroostook River & 1,666 & 654 & 853 & 159 \\
\hline Coastal Rivers & 1,306 & 427 & 726 & 153 \\
\hline Kennebec River & 3,160 & 1,089 & 1,584 & 487 \\
\hline Penobscot River & 5,490 & 2,305 & 2,605 & 580 \\
\hline Saco River & 945 & 262 & 397 & 286 \\
\hline St. John's River & 2,814 & 1,523 & 903 & 388 \\
\hline All drainages & 17,169 & 6,777 & 7,933 & 2,459 \\
\hline
\end{tabular}

Table 20.--Commercial forest 1 and area, by ownership and stand-size class,

$$
\text { Maine, } 1959
$$

(In thousands of acres)

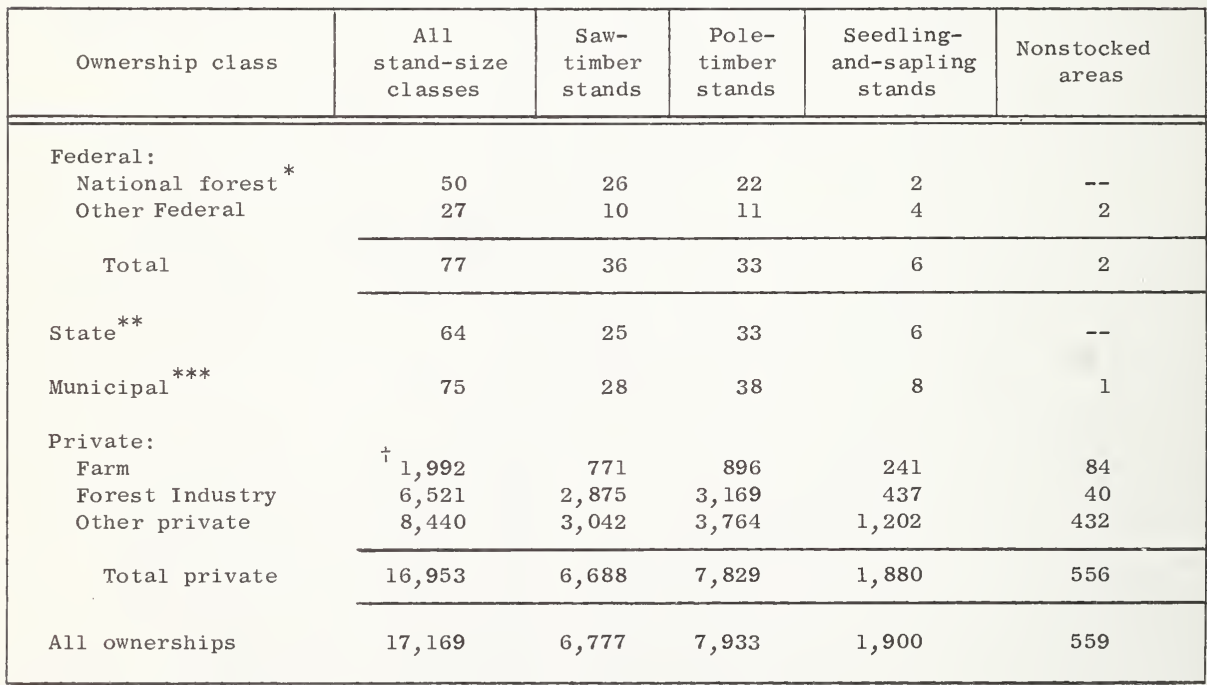

* National forest ownership as of December 9, 1958. (White Mountain National Forest acreage is 45,862 acres; remainder is in the Massabesic Experimental Forest.)

** State ownership as of November $28,1958$.

*** Municipal ownership as of April 20, 1959. (There is no county-owned forest land in Maine.)

${ }^{+}$Census of Agriculture, 1954. 
Table 21.--Number of private owners and total acreage of privately-owned commercial forest 1 and, by size-of-holding class, Maine, 1959

\begin{tabular}{|c|c|c|}
\hline $\begin{array}{l}\text { Size-of-holding } \\
\text { class (in acres) }\end{array}$ & $\begin{array}{c}\text { Number of } \\
\text { owners }\end{array}$ & $\begin{array}{c}\text { Thousand } \\
\text { acres }\end{array}$ \\
\hline Less than 100 & 62,557 & 4,121 \\
\hline 100 to 500 & 14,265 & 2,788 \\
\hline 500 to 5,000 & 528 & 770 \\
\hline Total, small ownerships * & 77,350 & 7,679 \\
\hline 5,000 to 50,000 & 51 & 898 \\
\hline 50,000 and over & 23 & 8,376 \\
\hline Total, large ownerships ${ }^{* *}$ & 74 & 9,274 \\
\hline Total, all ownerships & 77,424 & 16,953 \\
\hline
\end{tabular}

* Source: U. S. Forest Service, Timber Resources for America's Future, 1958. There is no recent estimate (since 1952) of the number of owners by size-of-holding class; however the acreages have been adjusted to conform with the 1959 data for large ownerships.

** Source: Maine Forest Service, 1959.

Table 22.--Land area and commercial forest land area, by counties, Maine, 1959

\begin{tabular}{|c|c|c|c|}
\hline \multirow[t]{3}{*}{ County } & $\begin{array}{l}\text { Land } \\
\text { area }\end{array}$ & \multicolumn{2}{|c|}{$\begin{array}{l}\text { Commercial } \\
\text { forest-land area }\end{array}$} \\
\hline & Thous and & Thous and & \\
\hline & acres & acres & Percent \\
\hline Androscogg in & 306 & 230 & 75 \\
\hline Aroos took & 4,355 & 3,854 & 88 \\
\hline Cumberl and & 564 & 503 & 89 \\
\hline Franklin & 1,099 & 919 & 84 \\
\hline Hancock & 987 & 759 & 77 \\
\hline Kennebec & 554 & 438 & 79 \\
\hline Knox & 232 & 194 & 84 \\
\hline Lincoln & 292 & 245 & 84 \\
\hline Oxford & 1,334 & 1,068 & 80 \\
\hline Penobscot & 2,181 & 1,971 & 90 \\
\hline Piscataquis & 2,527 & 2,319 & 92 \\
\hline Sagadahoc & 164 & 141 & 86 \\
\hline Somerset & 2,527 & 2,155 & 85 \\
\hline Waldo & 470 & 326 & 69 \\
\hline Washington & 1,634 & 1,573 & 96 \\
\hline York & 640 & 474 & 88 \\
\hline Total & 19,866 & 17,169 & 86 \\
\hline
\end{tabular}




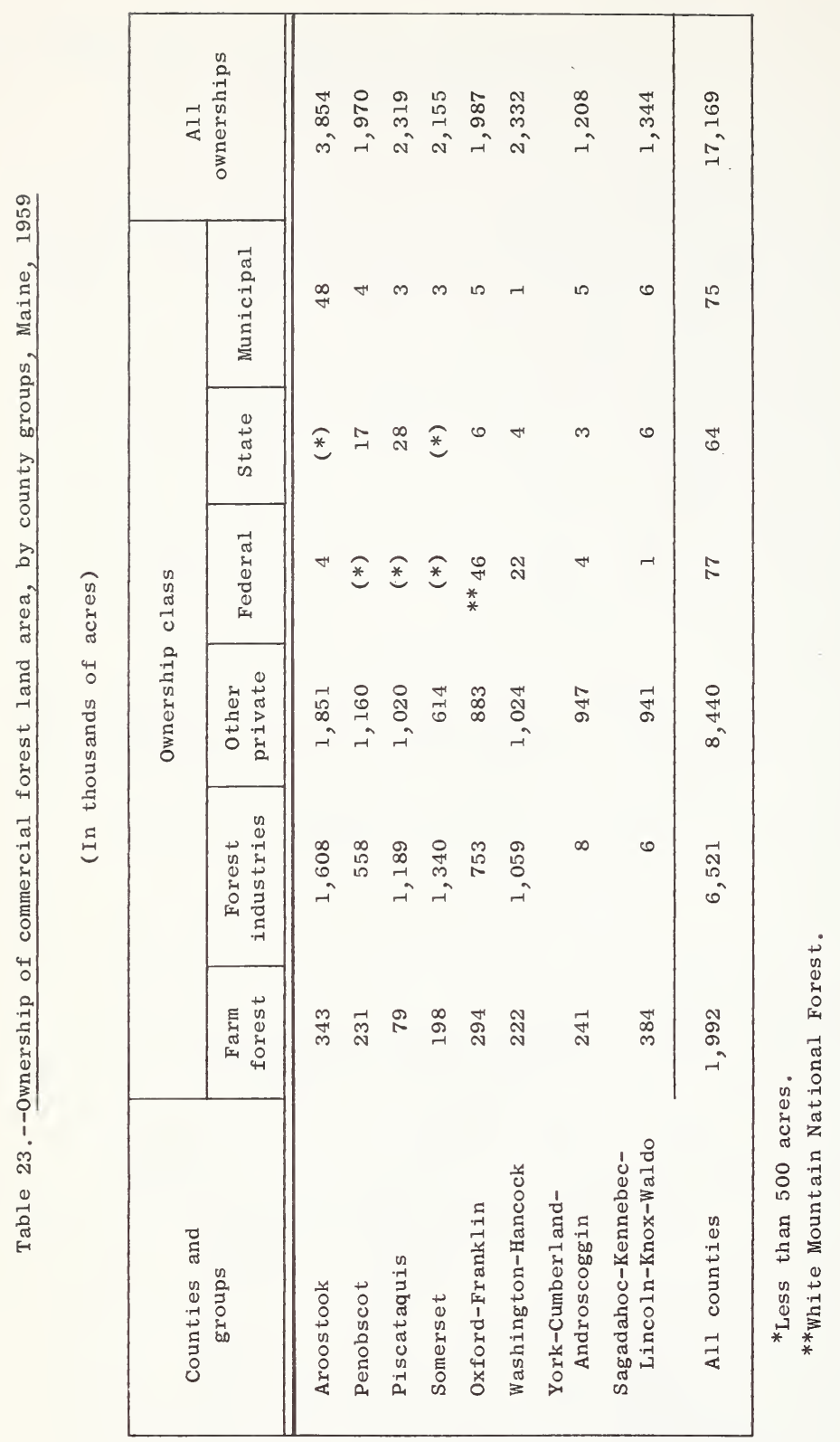




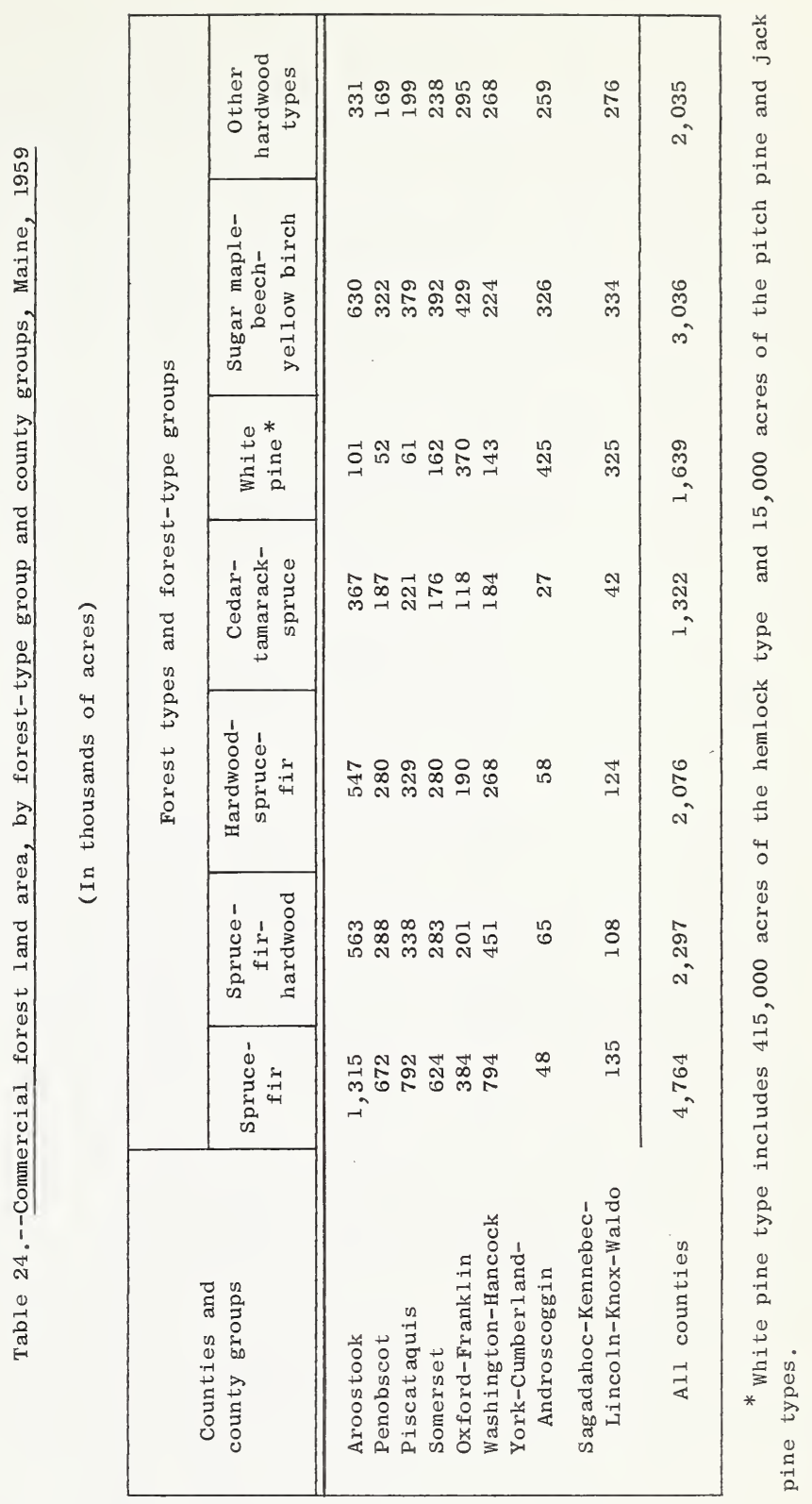




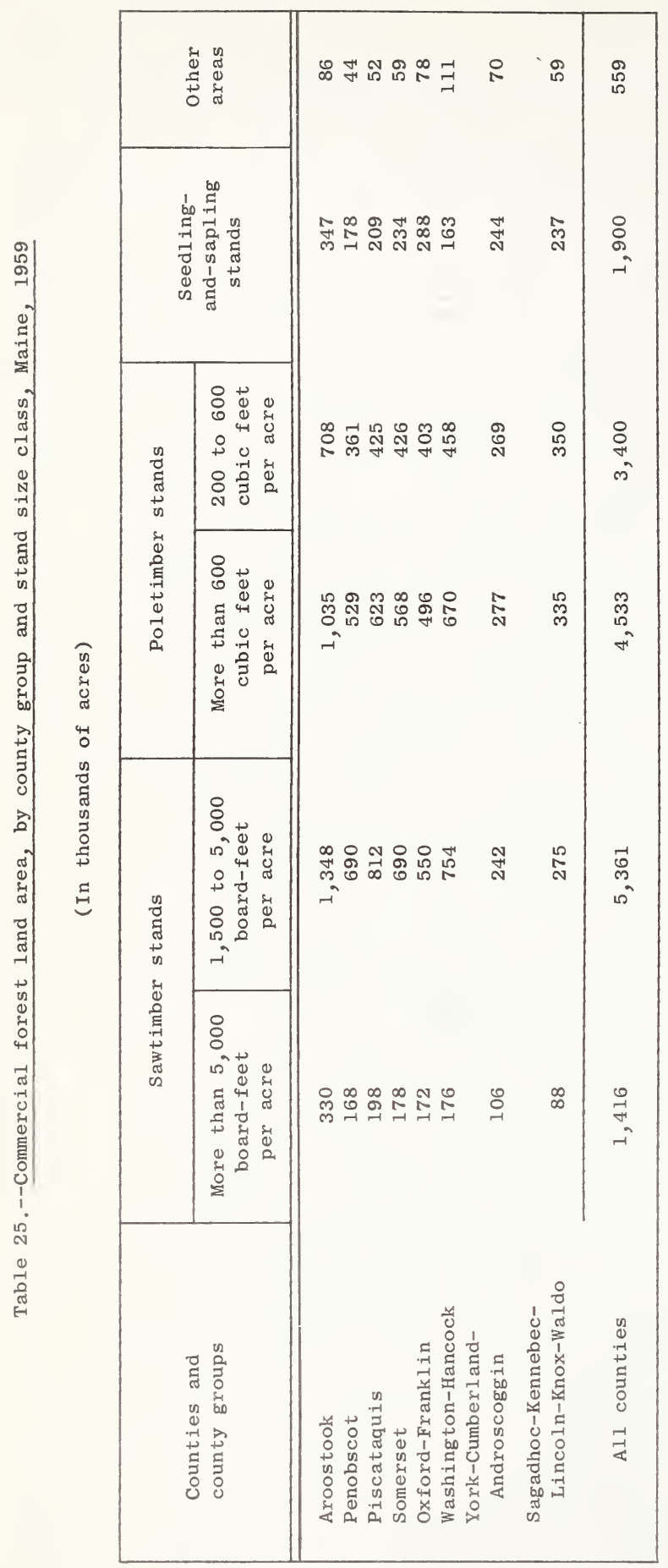




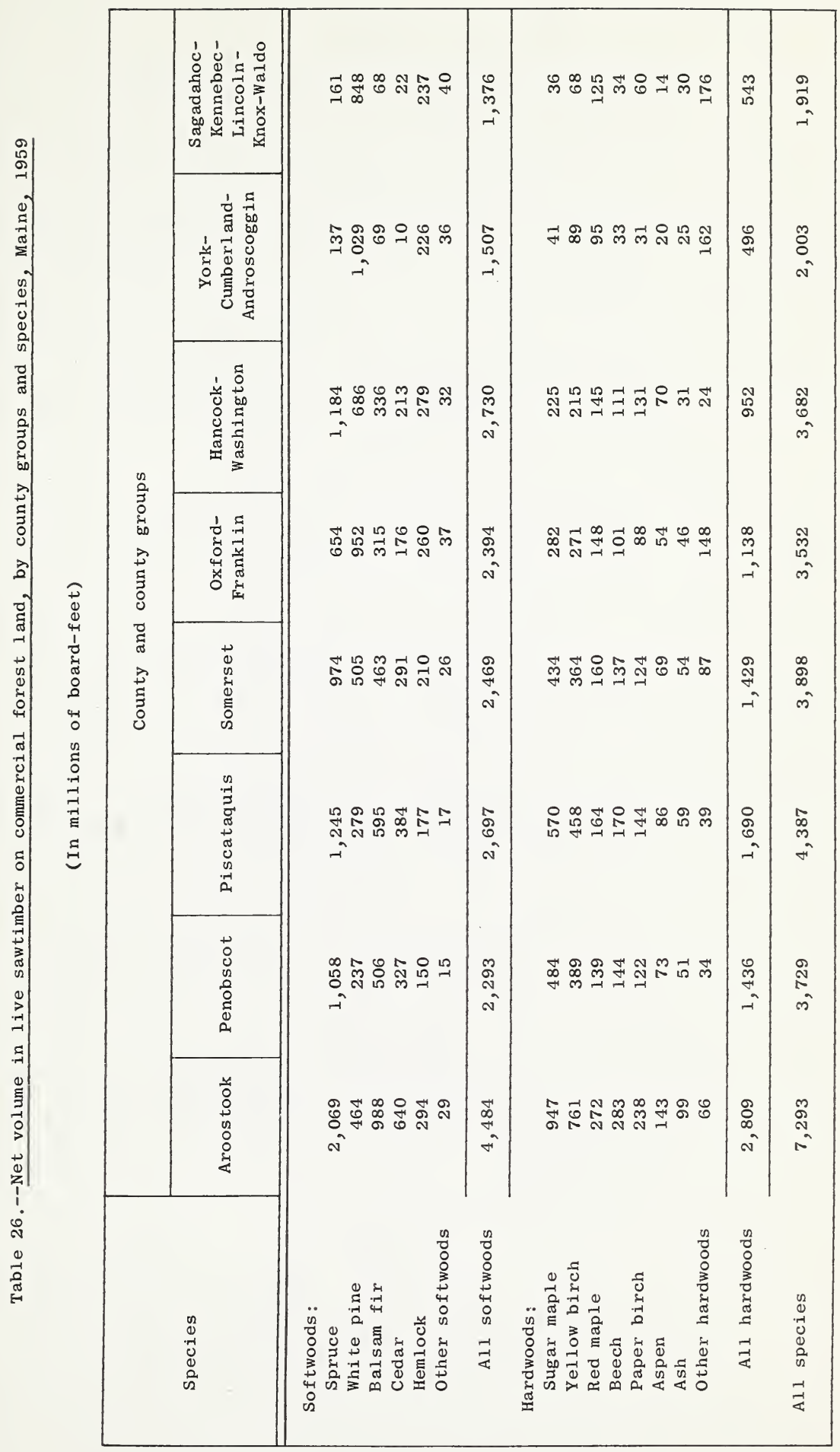




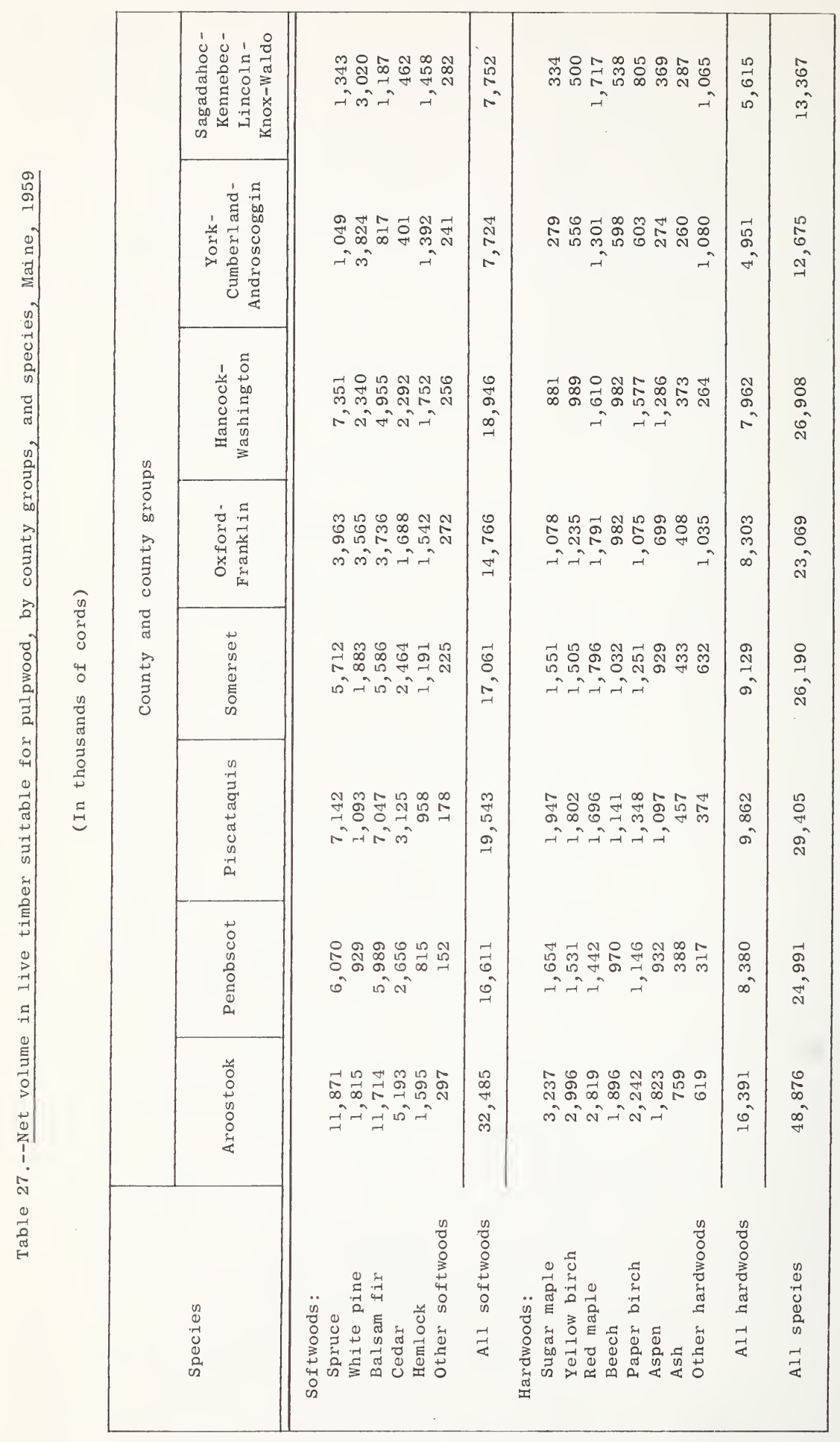




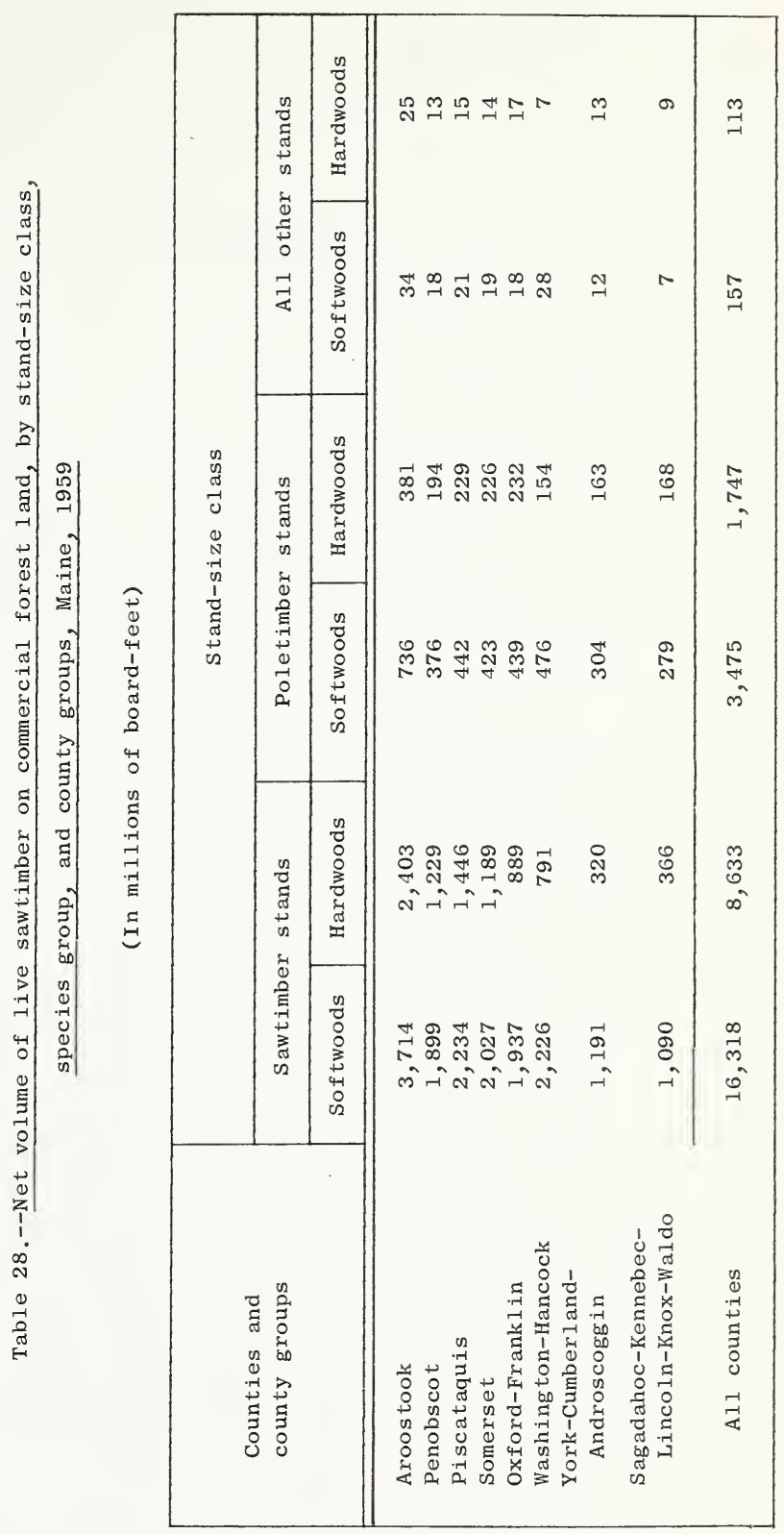




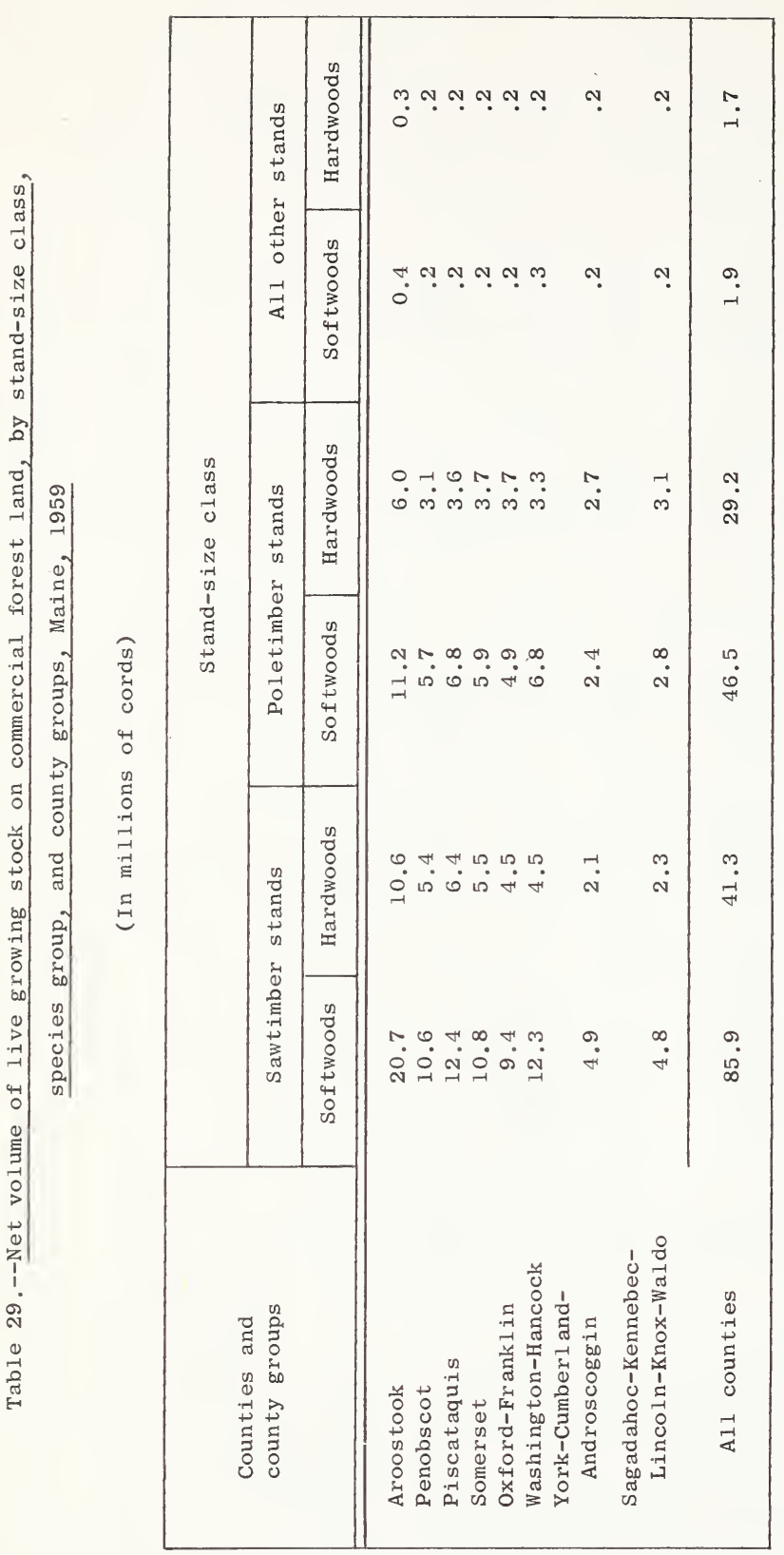




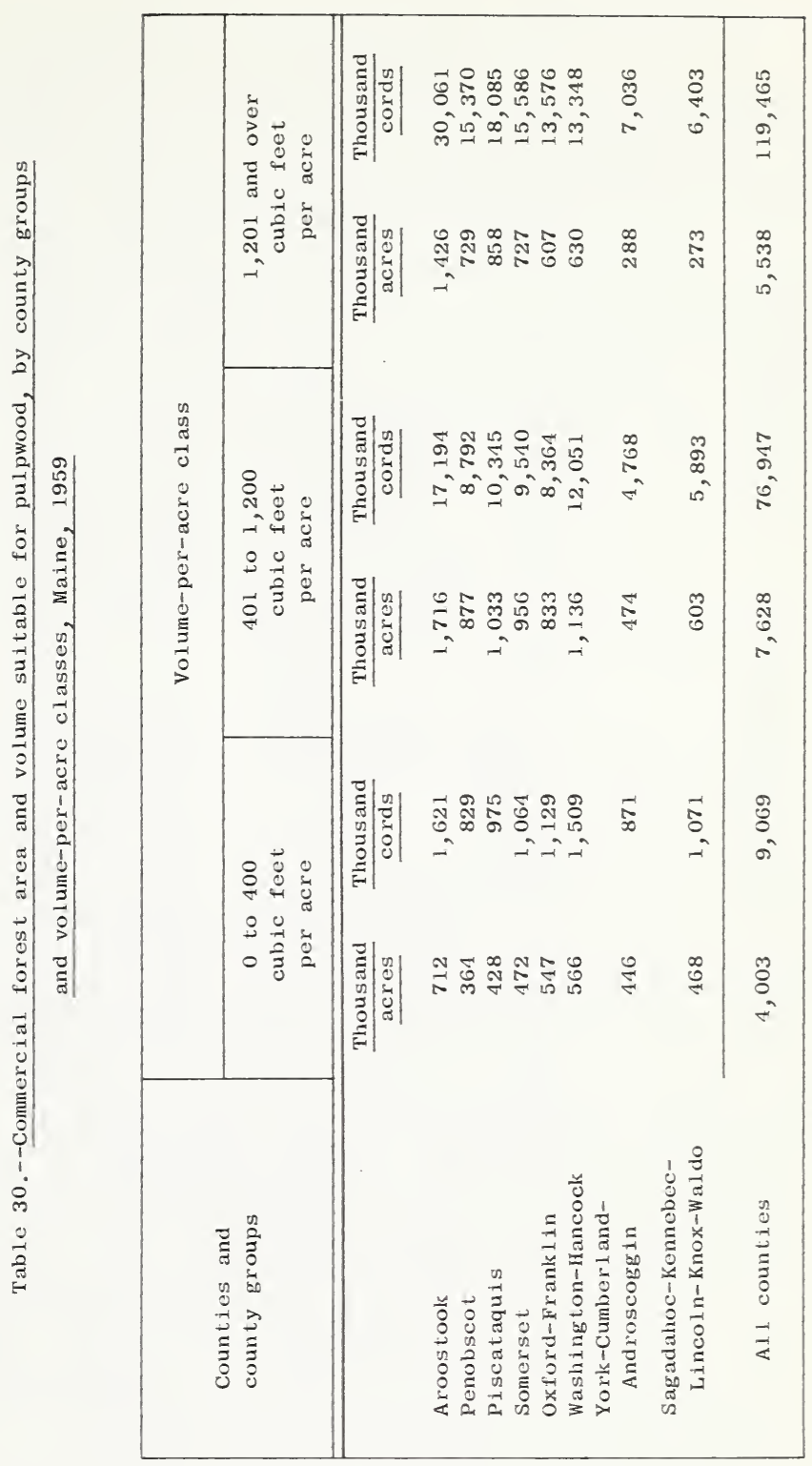




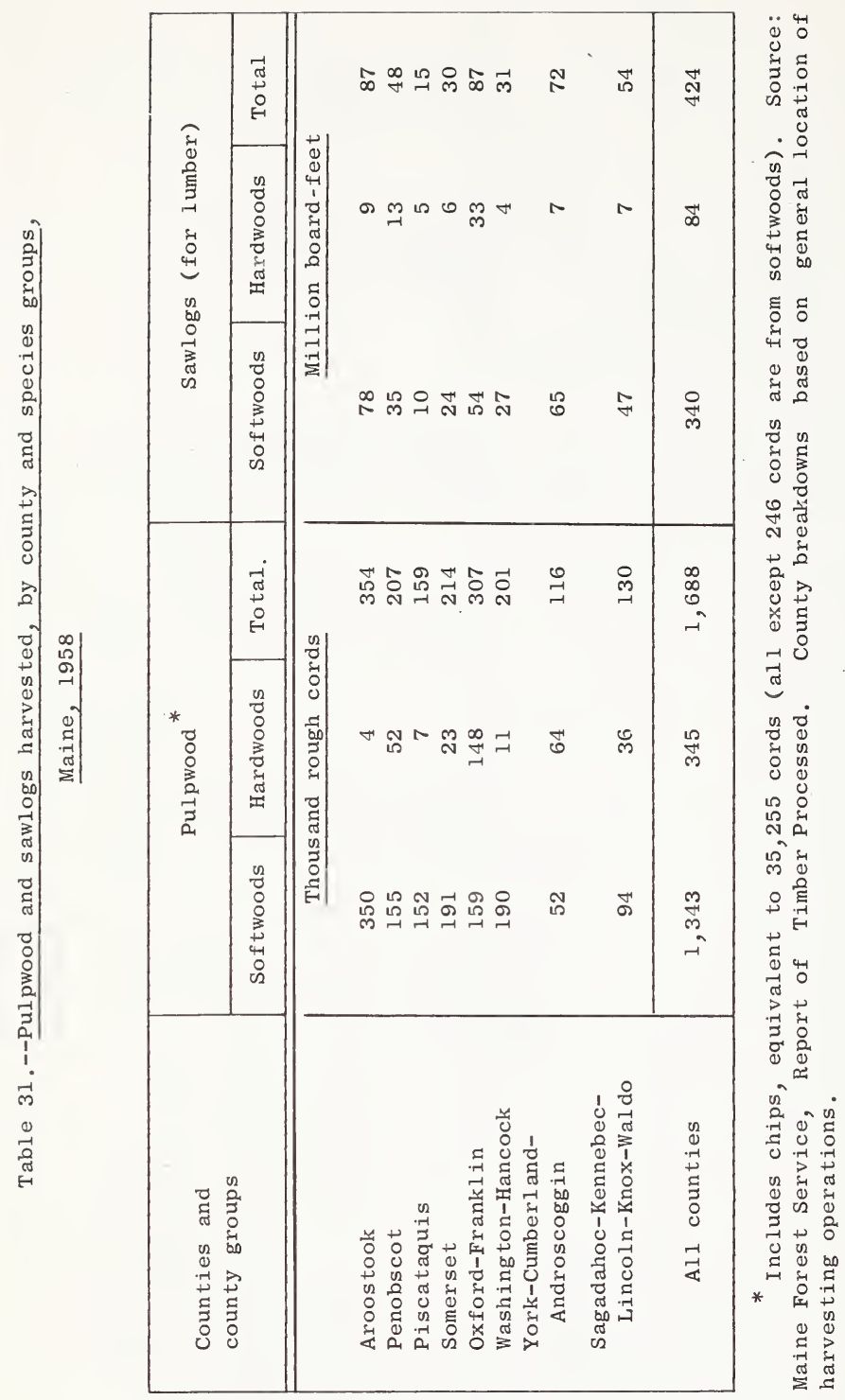


(Continued from page 44.)

combination. In Maine it includes the red maple and ash-elm-maple types.

Maple-beech-birch. - Forests in which 50 percent or more of the stand is sugar. maple, beech, or yellow birch, singly or in combination. In Maine, it includes the sugar maple - beech - yellow birch, hardwood - spruce - fir, and hardwood - white pine types.

Aspen-birch. - Forests in which 50 percent or more of the stand is aspen, paper birch, or gray birch, singly or in combination. In Maine it includes the aspen, gray birch-pin cherry, and paper birch types.

\section{Class of Timber}

Sawtimber trees.- - Trees of commercial species that: (a) are of the following minimum diameters at breast height softwoods 9.0 inches and hardwoods 11.0 inches; (b) contain at least one merchantable sawlog; and (c) contain at least 50 percent sound volume in the sawlog portion of the tree. (A merchantable saw$\log$ is a portion of a live tree that meets the minimum log-grade specifications, as defined under log-grade classification. The sawlog portion is that part of the tree between stump and the top of the last merchantable sawlog.)

Poletimber trees. - Trees of commercial species that meet regional specifications of soundness and form, and are of the following diameters at breast height; softwoods 5.0 to 9.0 inches; hardwoods 5.0 to 11.0 inches. Such trees will usually become sawtimber trees if left to grow.

Seedling-and-sapling trees.-Live trees of commercial species less than 5.0 inches in diameter at breast height and of good form and vigor.

Cull trees.-Live trees of sawtimber or poletimber size that are unmerchantable for sawlogs now or prospectively because of defect or rot, or because they are of undesirable species.

Hardwood limbs.-Limbs of hardwood sawtimber trees and sawtimber-size cull hardwood trees to a minimum diameter of 4.0 inches inside bark.

Pulpwood trees. - Live trees of commercial species, 5.0 inches d.b.h. and larger, including sawtimber, poletimber, and even cull trees that contain at least two contiguous pulpwood bolts and of which 50 percent or more of the mainstem volume is usable for pulpwood.

\section{Stand-Size Classes}

Sawtimber stands. - Stands with sawtimber trees having a minimum net volume per acre of 1,500 board-feet, International $1 / 4$-inch rule.

Poletimber stands.- -Stands that fail to meet the sawtimber stand specification, but that are at least 10 percent stocked with poletimber and larger trees (5.0 inches d.b.h. and larger), and have at least one-half the minimum stocking in poletimber trees. Poletimber stands carry at least 200 cubic feet per acre.

Seedling-and-sapling stands. - Stands that do not qualify as either sawtimber or poletimber stands, but have at least 10 percent stocking of trees of commercial species, and have at least one-half the minimum stocking in seedling-and-sapling trees.

Nonstocked and other areas not elsewhere classified. - Areas that do not qualify as sawtimber, poletimber, or seedling-and-sapling stands; areas less than 10 percent stocked with trees of commercial species.

\section{Trmber Volume}

Growing stock.-Net volume, in cubic feet, of live sawitimber trees and live poletimber trees from stump to a minimum 4-inch top (of central stem) inside bark. Net volume $=$ gross volume less deduction for rot. 
Live sawtimber volume. - Net volume in board-feet, International $1 / 4$-inch rule, of merchantable sawlogs in live sawtimber trees of commercial species. Net volume $=$ gross volume in terms of the International $1 / 4$-inch rule less deductions for rot, sweep, and other defects affecting use for lumber.

Pulpwood volume. - Net volume in standard cords (including bark) of all trees that meet pulpwood tree specifications, regardless of whether or not these trees also meet sawtimber specifications. It includes the main stem from the stump to the point where the top breaks up into branches, or to a minimum top diameter of 4.0 inches (inside bark). Deductions are made for all portions of the stem that fail to meet pulpwood bolt requirements. The standard cord is a unit of measure for stacked wood, encompassing 128 cubic feet of wood, bark, and air space. Cord estimates are derived from cubicfoot measurements by applying a factor of 80 cubic feet of wood (inside bark) per rough cord

\section{Product Specifications}

The product specifications used in the forest survey for hardwood lumber logs, hardwood tie and timber logs, and white pine lumber logs are detailed in the following figures.

Pulpwood bolts. - A pulpwood bolt is a 4-foot section of the main stem of any commercial species tree 5.0 inches d.b.h. and larger; 4.0 inches or larger inside bark at the small end; free from any indication of rot, charred wood, metal, or hollow center; and contiguous to one or more other bolts that meet the same requirements. Crotches are excluded; sweep or crook in any section shall exclude the bolt if a line from center of top cut to center of bottom cut passes outside the wood at any point.

\section{Annual Growth and Cut}

Net annual growth of sawtimber. The change (resulting from natural causes) in net board-foot volume of live sawtimber on commercial forest land during a specified year.

Ingrowth of sawtimber. - The net board-foot volume of trees that first became sawtimber trees during the inventory year as measured at the end of the year.

Annual mortality of sawtimber. - The net board-foot volume removed yearly from live sawtimber on commercial forest land through death from natural causes.

Net annual growth of growing stock. -The yearly change (resulting from natural causes) in net cubic-foot volume of growing stock on commercial forest land.

Ingrowth of growing stock. - The total net cubic-foot volume of trees that first become a part of growing stock during the inventory year as measured at the end of the year.

Annual mortality of growing stock. The net cubic-foot volume removed from growing stock during a year through death from natural causes.

Annual cut of live sawtimber. - The net board-foot volume of live sawtimber trees cut or killed by logging, land-clearing, or cultural operations on commercial forest land during a year.

Annual cut of growing stock.-The net cubic-foot volume of live sawtimber and poletimber trees cut or killed by logging, land-clearing, or cultural operations on commercial forest land during a year.

\section{FOREST SURVEY METHODS}

Our estimates of forest area, timber volume, and growth are based upon information obtained from aerial photographs and from sample plots examined 


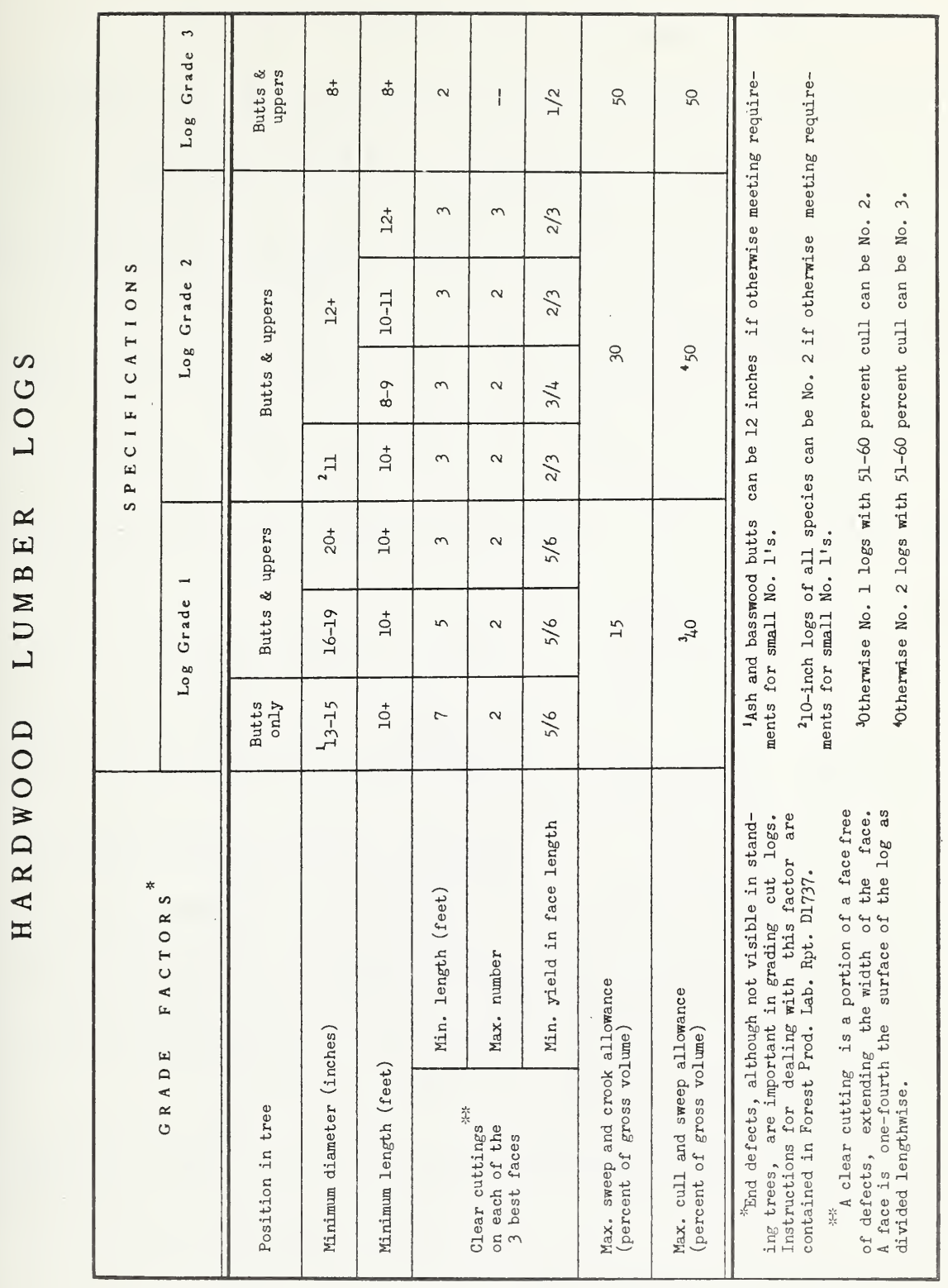

Grade standards used for hardwood

lumber logs in the forest survey of Maine.

on the ground. First, photo-interpretation plots were marked off on aerial photographs. These plots were distributed uniformly by mechanical means over photographs of the entire State. Each photo

plot was then classified as either forest or non-forest. Forest plots were classified further according to volume class and broad forest type.

Field crews then inspected some of the photo plots on the ground. Enough plots were selected at random to attain specified levels of statistical accuracy. Species 


\section{T I E AND T I B E R LOG S}

\begin{tabular}{|c|c|c|}
\hline G R A D E & F A C T O R S & S PECIFICATION S \\
\hline \multicolumn{2}{|l|}{ Position in tree } & Butts and uppers \\
\hline \multicolumn{2}{|c|}{ Scaling diameter (inches) } & $8+$ \\
\hline \multicolumn{2}{|c|}{ Length, without trim (feet) } & $8+$ \\
\hline \multicolumn{2}{|l|}{ Clear cuttings } & No requirements: not graded on cutting basis. \\
\hline \multicolumn{2}{|c|}{ Max. sweep allowance } & $\begin{array}{l}\text { One-fourth d.i.b. of small end for half logs, } \\
\text { and one-half d.i.b. for logs } 16 \text { feet long. }\end{array}$ \\
\hline \multirow{3}{*}{$\begin{array}{l}\text { Sound } \\
\text { surface defects } \\
\text { permitted }\end{array}$} & Single knots & $\begin{array}{l}\text { Any number, if none has an average collar* } \\
\text { diameter that is more than one-third of log } \\
\text { diameter at point of occurrence }\end{array}$ \\
\hline & Whorled knots & $\begin{array}{l}\text { Any number, provided the sum of the collar } \\
\text { diameters does not exceed one-third the log } \\
\text { diameter at point of occurrence. }\end{array}$ \\
\hline & Holes & $\begin{array}{l}\text { Any number not exceeding knot specifications } \\
\text { if they do not extend more than } 3 \text { inches into } \\
\text { the contained tie or timber. }\end{array}$ \\
\hline $\begin{array}{l}\text { Unsound } \\
\text { surface defects } \\
\text { permitted }\end{array}$ & \multicolumn{2}{|c|}{$\begin{array}{l}\text { Any number and size if they do not extend into contained tie or } \\
\text { timber. If they extend into contained tie or timber, they shall } \\
\text { not exceed size, number, and depth of limits for sound defects. }\end{array}$} \\
\hline \multicolumn{3}{|c|}{$\begin{array}{l}\text { *Knot collar is the average of the vertical and horizontal diameters of the limb } \\
\text { or knot swelling as measured flush with the surface of the log. } \\
\text { ** Interior defects are not visible in standing trees. They are considered in } \\
\text { grading cut logs. No interior defects are permitted except one shake not more than } \\
\text { one-third the width of the contained tie or timber, and one split not more than } 5 \\
\text { inches long. }\end{array}$} \\
\hline
\end{tabular}

The standards used for hardwood tie and timber logs in the forest survey of Maine.

and volume data were collected on these ground plots; and the classification of stand size was verified.

Growth was computed from measurements of radial growth on selected trees; these measurements were applied to the estimated number of trees by species and diameter class in the timber inventory. Radial growth was measured on increment cores extracted from sample trees. The final estimate was of average annual periodic net growth at the time the inventory was made.

Estimates of timber cut in Maine were based on production surveys made in co- 
WH I TE P INE LOG GR A D S

\begin{tabular}{|c|c|c|c|c|}
\hline GFADE & $\begin{array}{l}\text { DIAMETER } \\
\text { inside bark, } \\
\text { small end } \\
\text { (inches) }\end{array}$ & $\begin{array}{l}\text { LENGTH } \\
\text { without trim } \\
\text { (feet) }\end{array}$ & $\begin{array}{l}\text { TOTAL } \\
\text { DEDUCTION } \\
\text { PERMITTED } \\
\text { (percent) }\end{array}$ & $\begin{array}{c}\text { SURFACE } \\
\text { REQUIREMENTS }\end{array}$ \\
\hline \multirow{3}{*}{1} & $13+$ & 8 & 0 & Surface clear $100 \%$ \\
\hline & $13-16$ & $12-16$ & 25 & $\begin{array}{l}\text { Must be } 2 / 3 \text { surface-clear in } \\
\text { lengths } 8 \text { feet long or longer or } \\
50 \% \text { surface-clear full length. }\end{array}$ \\
\hline & $17+$ & $10-16$ & 30 & $\begin{array}{l}\text { Must be } 1 / 2 \text { surface-clear in } \\
\text { lengths } 8 \text { feet long or longer or } \\
25 \% \text { surface-clear full length. }\end{array}$ \\
\hline \multirow{2}{*}{2} & $9-16$ & $10-16$ & 30 & $\begin{array}{l}\text { Permits sound, tight knots not } \\
\text { over } 2 \frac{1}{2} \text { inches in diameter. } \\
\text { Larger, sound, tight knots per- } \\
\text { mitted only if } 50 \% \text { of full- } \\
\text { length surface has no sound, } \\
\text { tight knots larger than } 2 \text { inches } \\
\text { in diameter. }\end{array}$ \\
\hline & $17+$ & $8-16$ & 40 & $\begin{array}{l}\text { Permits sound, tight knots not } \\
\text { over } 3 \text { inches in diameter. } \\
\text { Larger, sound, tight knots per- } \\
\text { mitted only if } 50 \% \text { of full- } \\
\text { length surface has no sound, } \\
\text { tight knots larger than } 2 \frac{1}{2} \text { inch- } \\
\text { es in diameter. }\end{array}$ \\
\hline \multirow{3}{*}{3} & $6-7$ & $8-16$ & 25 & $\begin{array}{l}\text { Permits sound knots not over } 1 \\
\text { inch in diameter or live knots } \\
\text { not over } 2 \text { inches in diameter. }\end{array}$ \\
\hline & $8-13$ & $8-16$ & 30 & $\begin{array}{l}\text { No surface requirements except } \\
\text { logs with knots } 4 \text { inches or more } \\
\text { in diameter in whorls less than } \\
2 \text { feet apart will not be accept- } \\
\text { ed unless } 15 \% \text { or more of full } \\
\text { length surface has no sound } \\
\text { knots over } 2 \text { inches in diameter. }\end{array}$ \\
\hline & $14+$ & $8-16$ & 40 & $\begin{array}{l}\text { No surface requirements except } \\
\text { that knots over } 6 \text { inches in di- } \\
\text { ameter cannot be closer than } 3 \\
\text { feet. }\end{array}$ \\
\hline
\end{tabular}

${ }^{1}$ Includes sweep, rot, and other cull.

The grade standards used for white pine logs in the forest survey of Maine. 
operation with the Maine Forest Service and wood-utilization studies conducted by the Northeastern Forest Experiment Station. The production surveys yielded estimates of the output of all timber products. From studies conducted on all types of logging operations, estimates of logging residues were developed, which, when added to the volume of timber products, gave estimates of timber cut.

\section{RELIABILITY OF THE ESTIMATES}

The forest-area and timber-volume data presented in this report are based on a carefully designed sample of forest conditions throughout Maine. However, since not every tree in the State was measured, the figures in this report are estimates. A measure of the reliability of these estimates is given by the statistical "sampling error." Each estimate in this report has a sampling error, although not all of them have been computed.

Briefly, here is the way the sampling error indicates reliability. Our report of the total commercial forest area in Maine as $17,169,000$ acres, has an associated sampling error of 0.4 percent $(69,000$ acres). This means that our best estimate of the commercial forest area in Maine is $17,169,000$ acres. And if there are no errors in procedure the odds are 2 to 1 that if we repeated the survey, the new estimate of commercial forest area would be between 17,100,000 and 17,238,000 acres $(17,169,000 \pm 69,000)$. Similarly, the odds are 19 to 1 that it would be within $2 \times 69,000$ acres of the present estimate, and 300 to 1 that it would be within 207,000 acres of the present estimate.

Sampling errors for the various commercial-forest area and all-species inventory estimates in this report can be de- rived from the following tabulations. Sampling errors are somewhat higher for species, diameter, and other breakdowns of total volume or area.

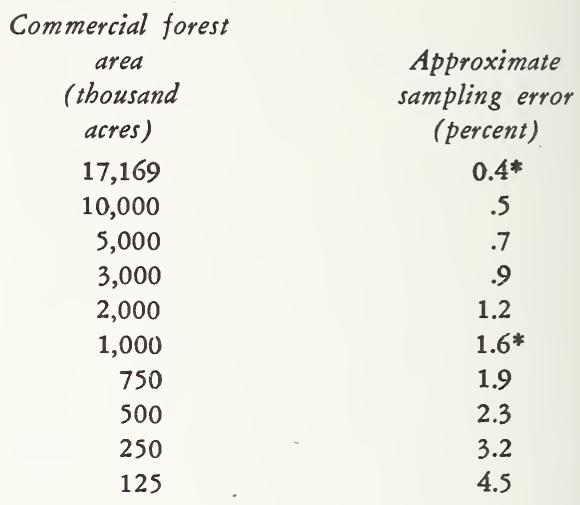

$\begin{array}{cc}\begin{array}{c}\text { Sawtimber } \\ \text { inventory } \\ \text { (million } \\ \text { bd.-ft.) }\end{array} & \begin{array}{c}\text { Approximate } \\ \text { sampling error } \\ \text { (percent) }\end{array} \\ 30,443 & 2.4^{*} \\ 15,000 & 3.4 \\ 10,000 & 4.1 \\ 5,000 & 5.8 \\ 4,000 & 6.5 \\ 3,000 & 7.5 \\ 2,000 & 9.1 \\ 1,000 & 12.8 \\ 750 & 14.8 \\ 500 & 18.0\end{array}$

$\begin{array}{cc}\begin{array}{c}\text { Pulpwood } \\ \text { inventory } \\ \text { (million } \\ \text { cords) }\end{array} & \begin{array}{c}\text { Approximate } \\ \text { sampling error } \\ \text { (percent) }\end{array} \\ 205.5 & 1.4^{*} \\ 100 . & 2.0 \\ 50 . & 2.8 \\ 25 . & 3.9 \\ 20 . & 4.4 \\ 15 . & 5.1 \\ 10 . & 6.0 \\ 7.5 & 7.1 \\ 5.0 & 8.7 \\ 2.5 & 12.2\end{array}$

*Computed sampling errors; others are estimated. 
Another use of reliability information is when one wishes to know, with some specified degree of confidence, that the volume of timber in an area is "at least" so much. For example, the best survey estimate of the net volume of sawtimber in Maine is 30,443 million board-feet (sampling error for this statistic $=2.4$ percent $=731$ million board-feet). If there are no errors in procedure, the chances are 5 to 1 that if we conducted a similar inventory, the estimate we would obtain would be "at least" 29,712 million board-feet $(30,443$ minus 731$)$ and 39 to 1 that it would be at least
28,981 million board-feet $(30,443$ minus 1,462).

Actually, even the computed sampling error is not a complete measure of reliability; there are other sources of "error" that this term does not include. There could be imperfections in the volume tables and errors in field measurements. However, the best volume tables available were used, and procedural errors were kept to a minimum by careful training of all personnel, frequent inspection of field work, and application of the most reliable survey methods.

\section{SPECIES TALLIED}

Only the tree species ${ }^{7}$ found on forest. survey sample plots in Maine are listed below. Other species that are found in Maine are not included.

\section{SOFTWOODS}

Spruce:

$\begin{array}{ll}\text { Red spruce } & \text { Picea rubens } \\ \text { White spruce } & \text { Picea glauca } \\ \text { Black spruce } & \text { Picea mariana } \\ \text { White pine: } & \\ \text { Eastern white pine } & \text { Pinus strobus } \\ \text { Red pine } & \text { Pinus resinosa } \\ \text { Balsam fir } & \text { Abies balsamea } \\ \text { Northern white-cedar } & \text { Thuja occidentalis } \\ \text { Eastern hemlock } & \text { Tsuga canadensis } \\ \text { Other eastern softwoods: } \\ \text { Pitch pine } & \text { Pinus rigida } \\ \text { Jack pine } & \text { Pinus banksiana } \\ \text { Tamarack } & \text { Larix laricina }\end{array}$

'Little, Elbert L., Jr. Check list of native and naturalized trees of the United States (including Alaska). U. S. Dept. Agr., Agr. Handb. 41, 472 pp., 1953.

\section{SOFT HARDwOOds}

Red maple:

Red maple

Silver maple

Paper birch

Aspen:

Bigtooth aspen

Quaking aspen

Other soft hardwoods:

Black ash

American basswood

Elm

Black cherry

Balsam poplar

Baisam poplar (Balm-of-Gilead)
Acer rubrum

Acer saccharinum

Betula papyrifera

Populus grandidentata

Populus tremuloides

Fraxinus nigra

Tilia americana

Ulmus species

Prunus serotina

Populus balsamifera

Populus balsamifera,

var. balsamifera

\section{HaRd HaRdwOOdS}

Sugar maple

Yellow birch

American beech

Ash:

White ash

Green ash

Northern red oak

Other hard hardwoods:

White oak

Hickory
Acer saccharum

Betula alleghaniensis

Fagus grandifolia

Fraxi nus americana

Fraxinus pennsylvanica

Quercus rubra

Quercus alba

Carya species 


\section{ACKNOWLEDGMENTS}

M ANY individuals and agencies contributed to the forest survey of Maine. The Maine Forest Service loaned aerial photographs for areas not already covered by suitable photography; and provided office space and quarters for forest-survey crews, airplane travel to otherwise inaccessible areas, financial assistance, information on forest-land ownership, and information on output of timber products.

The State of Maine Bureau of Taxation lent aerial photographs for a large part of Aroostook County. The Maine Public Service Company provided field quarters and house-trailer space for the forest-survey crews. The J. W. Sewall Company, forestry consultants, gave valuable help and advice.

The Forest Industries in Maine also were very cooperative. Some companies lent aerial photographs for a large part of the State. These companies are: Eastern Corporation (now Standard Packaging Corporation), Great Northern Paper Company, International Paper Company, Oxford Paper Company, Penobscot Development Company, Scott Paper Company, and S. D. Warren Company. Some companiesEastern Corporation (Standard Packaging Corporation), Penobscot Development Company, Prentiss \& Carlisle Company, and St. Regis Paper Companyremeasured forest-survey plots in Hancock County to bring the forest statistics up to date.

All this assistance is gratefully acknowledged. 



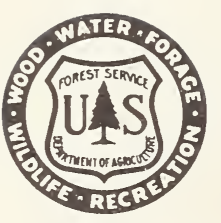

